Nevada

Environmental

Restoration

Project

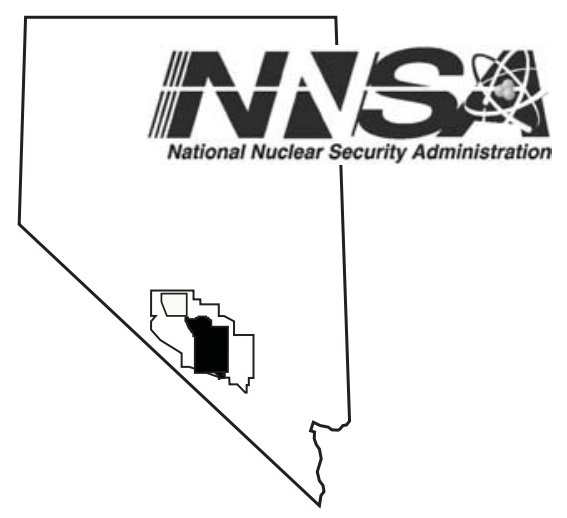

\title{
Completion Report for Well ER-12-2
}

November 2004

\section{Environmental Restoration}

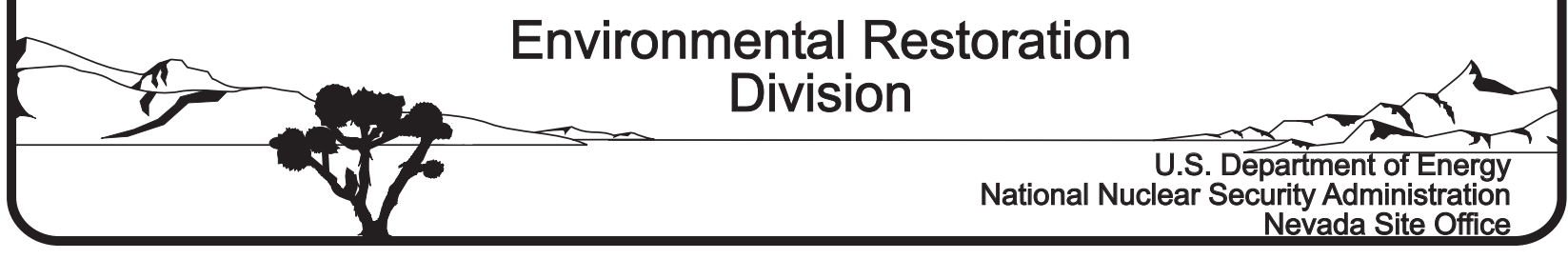




\title{
DISCLAIMER STATEMENT
}

Reference herein to any specific commercial product, process, or service by trade name, trademark, manufacturer, or otherwise, does not necessarily constitute or imply its endorsement, recommendation, or favoring by the U.S. Government or any agency thereof or its contractors or subcontractors.

\section{AVAILABILITY STATEMENT}

Available to the public, in paper, from-

\author{
U.S. Department of Commerce \\ National Technical Information Service \\ 5285 Port Royal Road \\ Springfield, VA, 22161-0002 \\ Telephone: 800.553 .6847 \\ Fax: 703.605.6900 \\ E-mail: orders@ntis.gov \\ Online ordering: http://www.ntis.gov/ordering.htm
}

Available electronically at http://www.osti.gov/bridge.

Available for a processing fee to U.S. Department of Energy and its contractors, in paper, from-

U.S. Department of Energy

Office of Scientific and Technical Information

P.O. Box 62

Oak Ridge, TN 37831-0062

Telephone: 865.576 .8401

Fax: 865.576.5728

E-mail: reports@adonis.osti.gov 
DOE/NV/11718--846

\section{Completion Report for Well ER-12-2}

Prepared for:

U.S. Department of Energy

National Nuclear Security Administration

Nevada Site Office

Las Vegas, Nevada

Prepared by:

Bechtel Nevada

Geotechnical Sciences

Las Vegas, NV

November 2004 
This page intentionally left blank. 


\section{COMPLETION REPORT FOR WELL ER-12-2}

Approved by: Robent Mn. Rampertes \&n. fo William R. Wilborn, Acting Project Manager, Underground Test Area Project

Date: $12 / 29 / 04$

Approved by: Rolert M. Arangestes Ps. Date:/2/29/04

Environmental Restoration Division 
This page intentionally left blank. 


\title{
Completion Report for Well ER-12-2 \\ DOE/NV/11718--846
}

\begin{abstract}
Well ER-12-2 was drilled for the U.S. Department of Energy, National Nuclear Security Administration Nevada Site Office, in support of the Nevada Environmental Restoration Project at the Nevada Test Site, Nye County, Nevada. The well was drilled from November 2002 to January 2003 as part of a hydrogeologic investigation program for the Yucca Flat Corrective Action Unit. The overall purpose of the well was to gather subsurface data to better characterize the hydrogeology in the northwestern portion of Yucca Flat. The well was drilled to total measured depth of 2,097.9 meters. The 131.1-centimeter-diameter borehole was left open (i.e., uncased) below the base of the intermediate casing at 901.6 meters. A piezometer string was installed outside the surface casing to a depth of 176.4 meters to monitor a zone of perched water.
\end{abstract}

Data gathered during and shortly after hole construction include composite drill cuttings samples collected every 3 meters, sidewall core samples from 7 depths, various geophysical logs, and water level measurements. These data indicate that the well penetrated, in descending order, 137.5 meters of Quaternary and Tertiary alluvium, 48.8 meters of Tertiary volcanic rocks, 289.6 meters of Mississippian Chainman Shale, and 1,622.5 meters of Mississippian and Upper Devonian Eleana Formation consisting of shale, argillite, sandstone, quartzite, and limestone. Forty-seven days after the well was drilled the water level inside the main hole was tagged at the depth of 65.43 meters, and the water level inside the piezometer string was tagged at 127.14 meters. 
This page intentionally left blank. 


\section{Table of Contents}

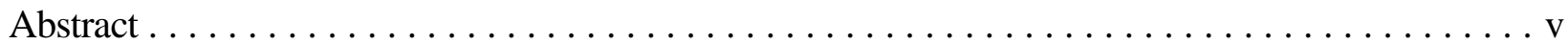

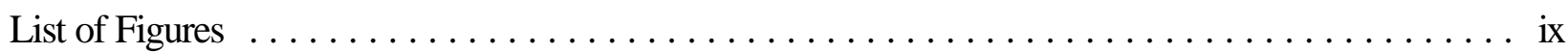

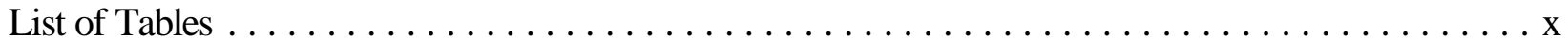

List of Acronyms and Abbreviations $\ldots \ldots \ldots \ldots \ldots \ldots \ldots \ldots \ldots \ldots \ldots \ldots \ldots \ldots \ldots \ldots \ldots$

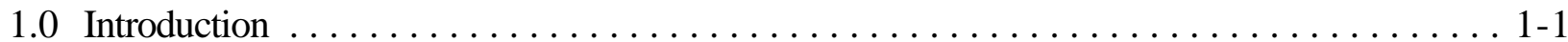

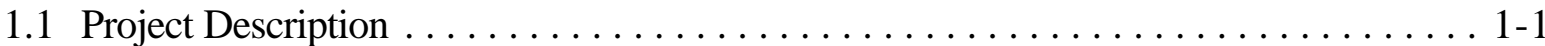

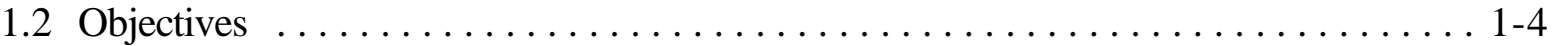

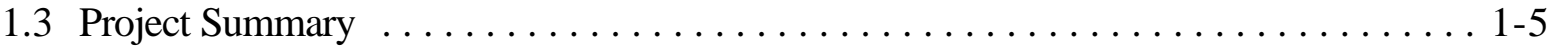

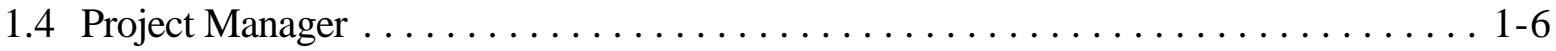

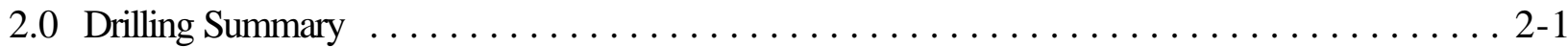

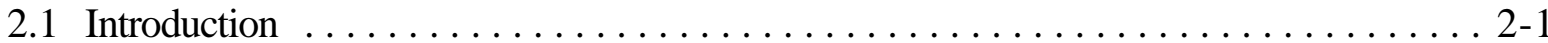

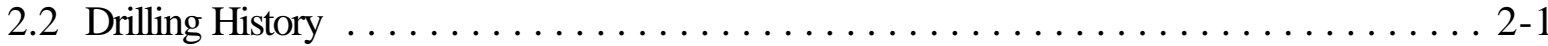

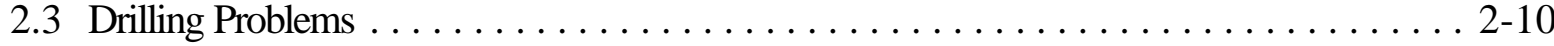

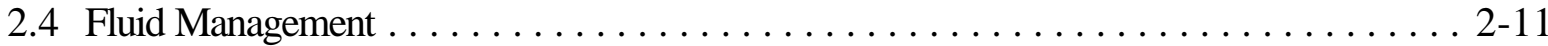

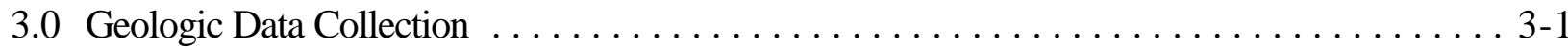

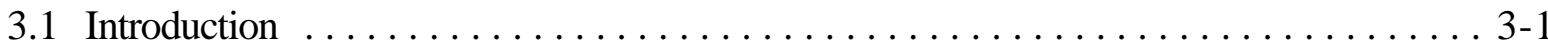

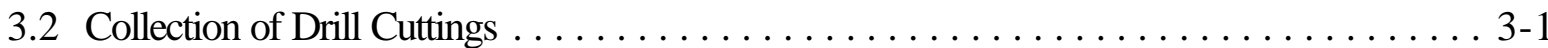

3.3 Sidewall Core Samples . . . . . . . . . . . . . . . . . . . . . . . . . . . . . 3-2

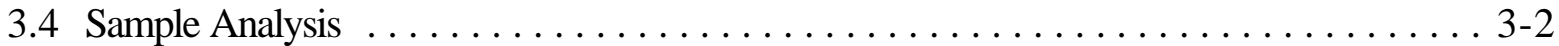

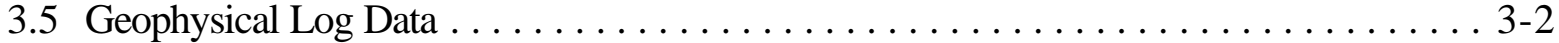

4.0 Geology and Hydrogeology $\ldots \ldots \ldots \ldots \ldots \ldots \ldots \ldots \ldots \ldots \ldots \ldots \ldots \ldots \ldots \ldots$

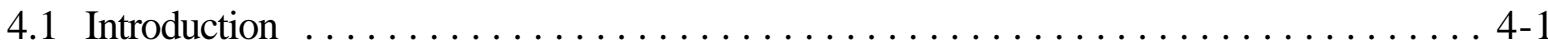

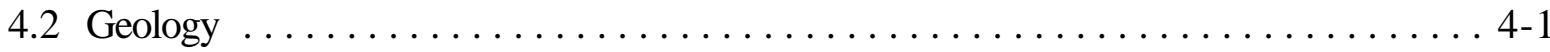

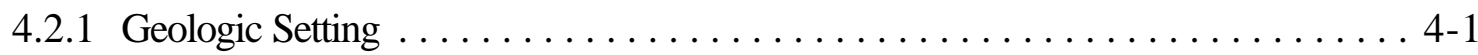

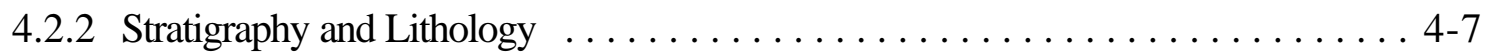

4.2 .3 Alteration . . . . . . . . . . . . . . . . . . . . . . . . . . . . . . 4-14

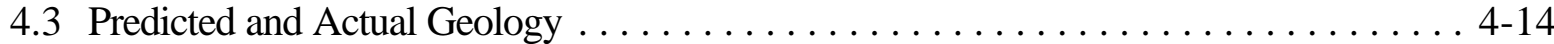

4.4 Hydrogeology . . . . . . . . . . . . . . . . . . . . . . . . . . 4-16 


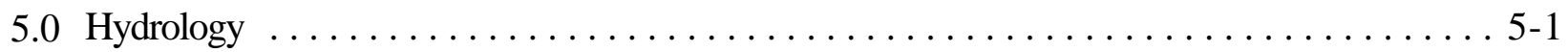

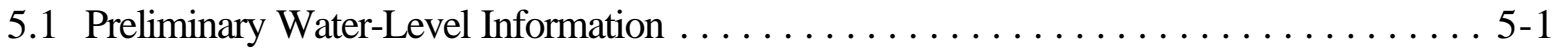

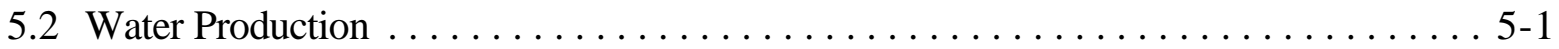

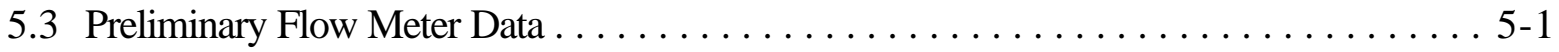

5.4 Preliminary Groundwater Characterization Samples $\ldots \ldots \ldots \ldots \ldots \ldots \ldots \ldots \ldots \ldots \ldots \ldots \ldots \ldots$

6.0 Precompletion and Open-Hole Development $\ldots \ldots \ldots \ldots \ldots \ldots \ldots \ldots \ldots \ldots \ldots$ 6-1

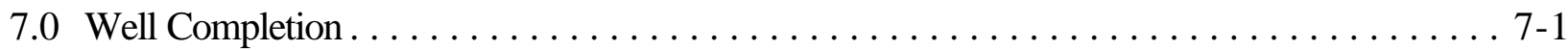

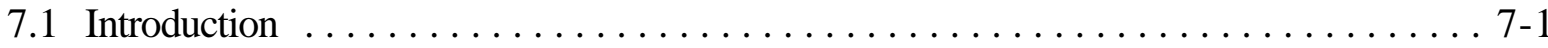

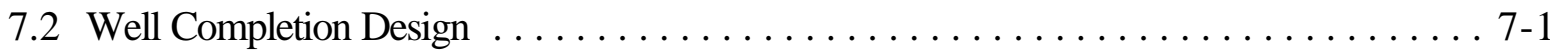

7.2.1 Proposed Completion Design $\ldots \ldots \ldots \ldots \ldots \ldots \ldots \ldots \ldots \ldots \ldots \ldots \ldots \ldots \ldots \ldots \ldots$

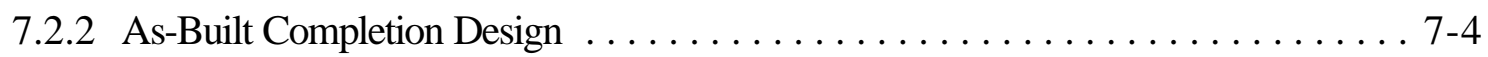

7.2.3 Rationale for Differences between Planned and Actual Well Design . . . . . . . . 7-4

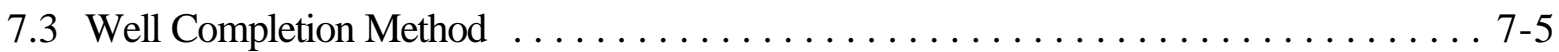

8.0 Planned and Actual Costs and Scheduling $\ldots \ldots \ldots \ldots \ldots \ldots \ldots \ldots \ldots \ldots \ldots \ldots \ldots \ldots \ldots \ldots$

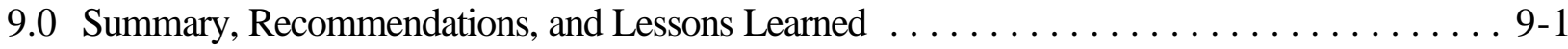

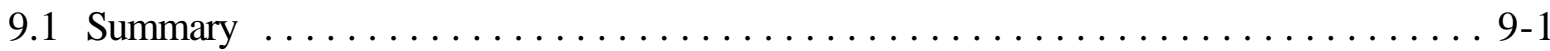

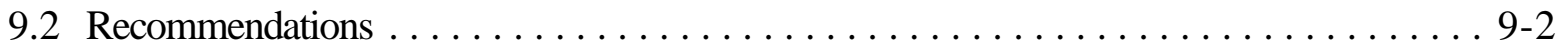

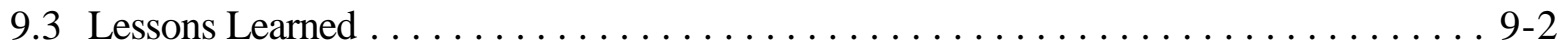

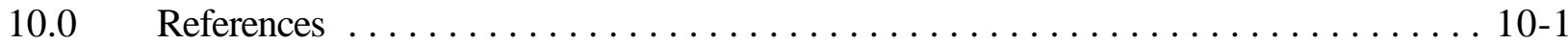

Appendix A - Drilling Data

A-1 Drilling Parameter Log for Well ER-12-2

A-2 Casing Data for Well ER-12-2

A-3 Well ER-12-2 Drilling Fluids and Cement Composition

Appendix B - Well ER-12-2 Fluid Management Data

Well ER-12-2 Fluid Disposition Reporting Form

Appendix C - Detailed Lithologic Log for Well ER-12-2

Appendix D - Geophysical Logs Run in Well ER-12-2

Distribution List 


\section{List of Figures}

Number

Title

Page

1-1 Reference Map Showing Location of Well ER-12-2 . . . . . . . . . . . . 1-2

2-1 Drill Site Configuration for Well ER-12-2 . . . . . . . . . . . . . . . . . 2-2

2-2 Well ER-12-2 Drilling and Completion History . . . . . . . . . . . . . . . 2-3

4-1 Generalized Surface Geologic Map of the Nevada Test Site Area Showing Location of Well ER-12-2 . . . . . . . . . . . . . . . . . . . . . 4-3

4-2 Surface Geologic Map of the Well ER-12-2 Site $\ldots \ldots \ldots \ldots \ldots \ldots \ldots \ldots \ldots .4 . \ldots$

4-3 Geology and Hydrogeology at Well ER-12-2 . . . . . . . . . . . . . . . . 4-9

4-4 Geologic Cross Section A-A' through Well ER-12-2 . . . . . . . . . . . . . . . . 4-11

4-5 Geologic Cross Section B-B' through Well ER-12-2 . . . . . . . . . . . . . . . 4-12

4-6 Predicted and Actual Stratigraphy at Well ER-12-2 . . . . . . . . . . . . . 4-15

4-7 Hydrogeologic Cross Section C-C' Through Well ER-12-2 . . . . . . . . . . . . . . 4-17

7-1 As-Built Completion Schematic for Well ER-12-2 . . . . . . . . . . . . . 7-2

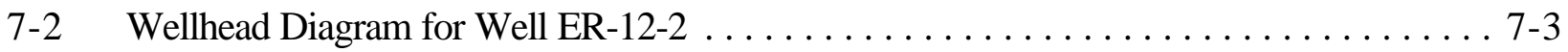

8-1 Planned and Actual Construction Progress for Well ER-12-2 . . . . . . . . . . 8-2

8-2 Planned and Actual Cost of Constructing Well ER-12-2 . . . . . . . . . . . 8-3 


\section{List of Tables}

Number

Title

Page

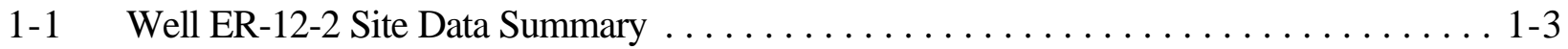

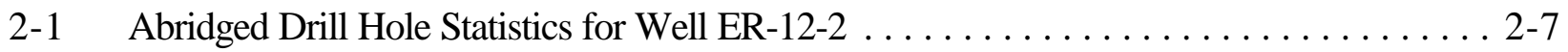

3-1 Sidewall Samples from Well ER-12-2 $\ldots \ldots \ldots \ldots \ldots \ldots \ldots \ldots \ldots \ldots \ldots \ldots \ldots \ldots \ldots \ldots \ldots \ldots$

3-2 Status of Rock Sample Analyses for Well ER-12-2 ................. 3-4

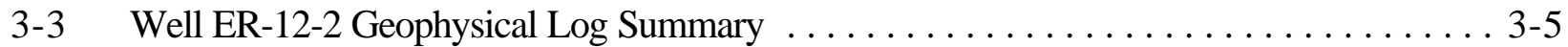

7-1 Well ER-12-2 Completion String Construction Summary $\ldots \ldots \ldots \ldots \ldots \ldots \ldots \ldots .7-4$

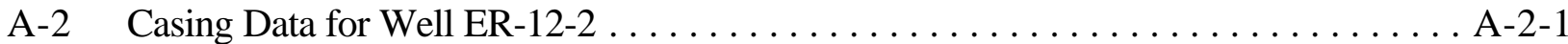

A-3-1 Drilling Fluids Used in Well ER-12-2 ....................... A-3-1

A-3-2 Well ER-12-2 Cement Composition ......................... A-3-1

D-1 Well ER-12-2 Geophysical Logs Presented $\ldots \ldots \ldots \ldots \ldots \ldots \ldots \ldots \ldots \ldots \ldots \ldots \ldots \ldots \ldots \ldots$ 


\section{List of Acronyms and Abbreviations}

\begin{tabular}{|c|c|}
\hline bbl & barrel(s) \\
\hline BHA & bottom-hole assembly \\
\hline $\mathrm{BN}$ & Bechtel Nevada \\
\hline $\mathrm{C}$ & centigrade \\
\hline CAU & Corrective Action Unit \\
\hline $\mathrm{cm}$ & centimeter(s) \\
\hline DOE & U.S. Department of Energy \\
\hline DOE/NV & U.S. Department of Energy, Nevada Operations Office \\
\hline DRI & Desert Research Institute \\
\hline $\mathrm{E}$ & east \\
\hline $\mathrm{EC}$ & electrical conductivity \\
\hline $\mathrm{F}$ & Fahrenheit \\
\hline FAWP & Field Activity Work Plan \\
\hline FMP & Fluid Management Plan \\
\hline $\mathrm{ft}$ & foot (feet) \\
\hline $\mathrm{ft}^{3}$ & cubic feet \\
\hline $\mathrm{ft} / \mathrm{hr}$ & feet per hour \\
\hline FY & fiscal year \\
\hline gpm & gallons per minute \\
\hline HES & Halliburton Energy Services \\
\hline HSU & hydrostratigraphic unit \\
\hline in. & inch(es) \\
\hline IT & IT Corporation \\
\hline $\mathrm{L}$ & liter(s) \\
\hline LCA & lower carbonate aquifer \\
\hline LCA3 & lower carbonate aquifer - thrust sheet \\
\hline $\mathrm{LiBr}$ & lithium bromide \\
\hline $\mathrm{lpm}$ & liters per minute \\
\hline LANL & Los Alamos National Laboratory \\
\hline $\mathrm{m}$ & meter(s) \\
\hline $\mathrm{m}^{3}$ & cubic meters \\
\hline $\mathrm{Ma}$ & million years (ago) \\
\hline $\mathrm{m} / \mathrm{hr}$ & meters per hour \\
\hline $\mathrm{N}$ & north \\
\hline NAD & North American Datum \\
\hline
\end{tabular}




\section{List of Acronyms and Abbreviations (continued)}

NNSA/NSO

NTS

Shaw

TD

UCCU

UGTA

UDI

USGS
U.S. Department of Energy, National Nuclear Security Administration Nevada Site Office

Nevada Test Site

Shaw Environmental, Inc.

total depth

upper clastic confining unit

Underground Test Area

United Drilling, Inc.

U.S. Geological Survey 


\subsection{Introduction}

\subsection{Project Description}

Well ER-12-2 was drilled for the U.S. Department of Energy (DOE), National Nuclear Security Administration Nevada Site Office (NNSA/NSO; formerly Nevada Operations Office, DOE/NV) in support of the Nevada Environmental Restoration Project at the Nevada Test Site (NTS), Nye County, Nevada. Well ER-12-2 is the third in a series of five wells drilled in Fiscal Year (FY) 2003 as part of the hydrogeologic investigation well drilling program for the Yucca Flat Corrective Action Unit (CAU). The Yucca Flat CAU and associated well drilling program are part of the NNSA/NSO Environmental Restoration Division's Underground Test Area (UGTA) project at the NTS. The goals of the UGTA project include evaluating the nature and extent of contamination in groundwater due to underground nuclear testing, and establishing a long-term groundwater monitoring network. As part of the UGTA project, scientists are developing computer models to predict groundwater flow and contaminant migration within and near the NTS. To build and test these models, it is necessary to collect geologic, geophysical, and hydrologic data from new and existing wells to define groundwater migration pathways, migration rates, and quality.

Well ER-12-2 is located in the southwest corner of NTS Area 12 in the northwest portion of Yucca Flat at an elevation of 1,434.2 meters (m) (4,705.3 feet [ft]) (Figure 1-1). Surface drainage in this area is to the southeast, into Yucca Flat proper. The Nevada State (central zone) plane coordinates (North American Datum [NAD] 1983) at the wellhead are North (N) 6,268,794.12 and East

(E) 548,245.19 m. Additional site data are listed in Table 1-1. The well is intended to provide information that will enhance the understanding of the hydrogeology of northwestern Yucca Flat.

Shaw Environmental, Inc. (Shaw) was the principal environmental contractor for the project, and Shaw personnel collected geologic and hydrologic data during drilling. The drilling company was United Drilling, Incorporated (UDI), a subcontractor to Bechtel Nevada (BN). Site supervision, engineering, construction, inspection, and geologic support were provided by BN. The roles and responsibilities of these and other contractors involved in the project are described in Contract Number DE-RP-0895NV11808, and in BN Field Activity Work Plan (FAWP) number D-010-002.03 (BN, 2002). The UGTA Technical Working Group, a committee of scientists and engineers comprising NNSA/NSO, Lawrence Livermore National Laboratory, Los Alamos National Laboratory (LANL), and 


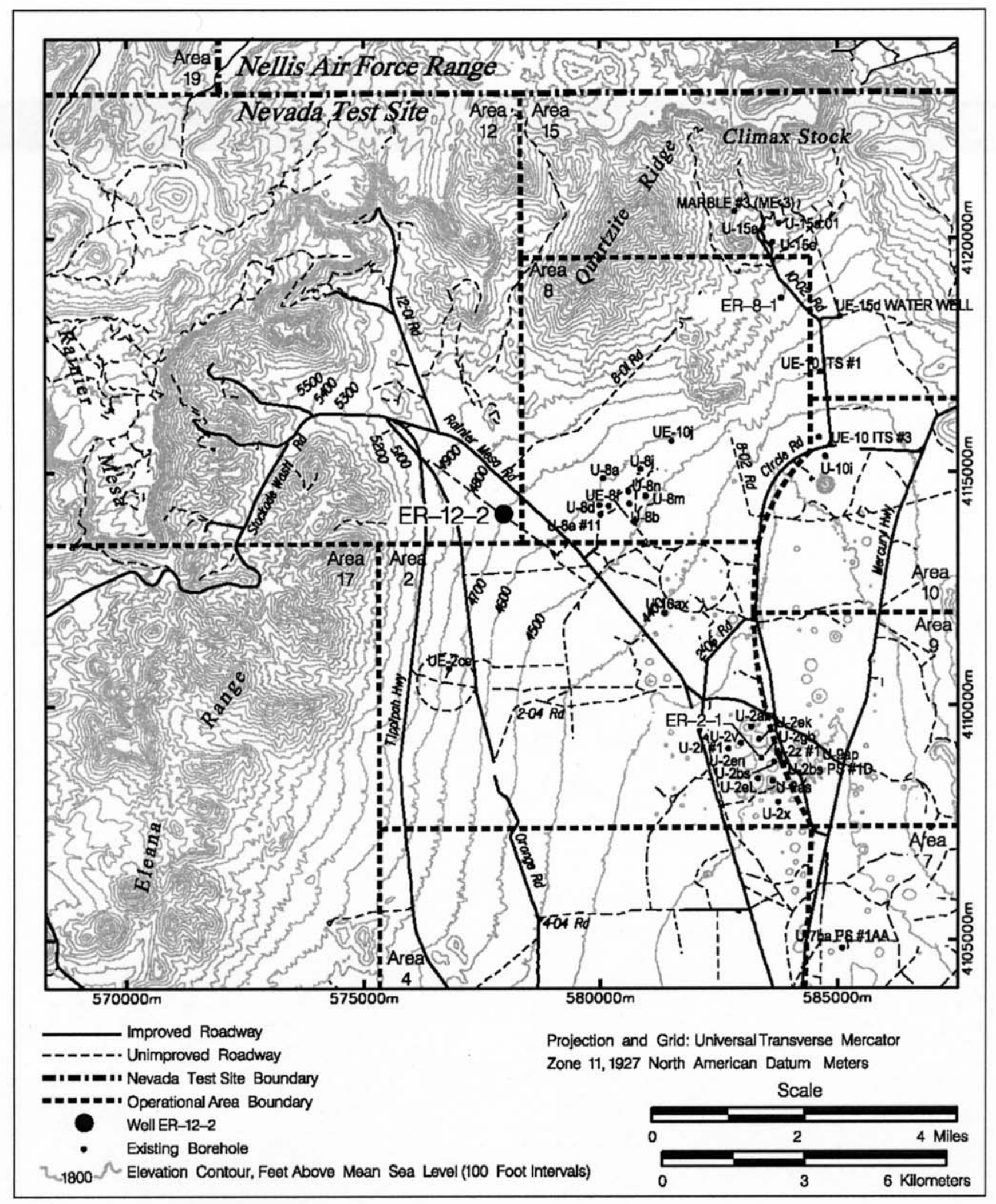

Figure 1-1

Reference Map Showing Location of Well ER-12-2 
Table 1-1

Well ER-12-2 Site Data Summary

\begin{tabular}{|c|c|}
\hline Well Designation & ER-12-2 \\
\hline Site Coordinates ${ }^{a}$ & 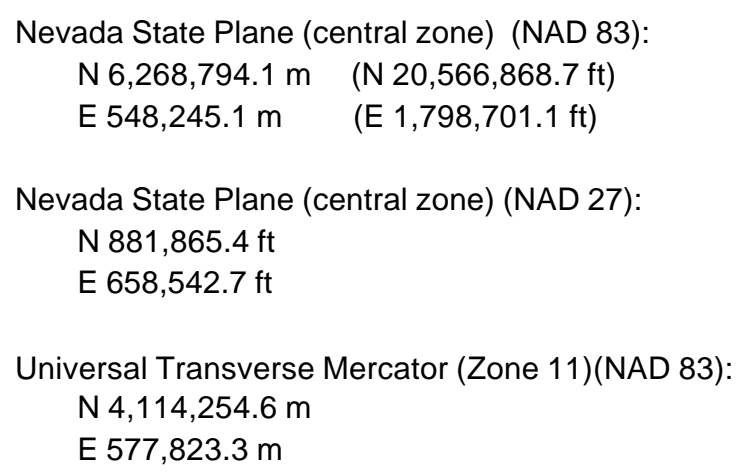 \\
\hline Surface Elevation $a, b$ & $1,434.2 \mathrm{~m}(4,705.3 \mathrm{ft})$ \\
\hline Drilled Depth & $2,097.9 \mathrm{~m}(6,883 \mathrm{ft})$ on January 15,2003 \\
\hline True Vertical Depth $^{c}$ & $1,896.2 \mathrm{~m}(6,221 \mathrm{ft})$ \\
\hline Current Depth & 2,093.7 m (6,869 ft) on April 15, 2003 \\
\hline Fluid-Level Depth ${ }^{d}$ & $65.43 \mathrm{~m}(214.67 \mathrm{ft})$ \\
\hline Fluid-Level Elevation & $1,368.74 \mathrm{~m}(4,490.63 \mathrm{ft})$ \\
\hline
\end{tabular}

a Measurement made by BN Survey.

b Elevation at top of construction pad. 1929 National Geodetic Vertical Datum.

c Depth below ground surface at TD is less than drilled depth due to severe borehole deviation. See Section 2.2.

d Measured by Shaw on March 3, 2003, in piezometer set in annulus of 20-in. casing, isolated within volcanic rocks (Shaw, 2003).

contractor personnel, provided additional technical advice during drilling, design, and construction of the well. See Yucca Flat Hydrogeologic Investigation Wells Drilling and Completion Criteria (IT, 2002) for descriptions of the general plan and goals of the Yucca Flat drilling initiative project, as well as specific goals for each planned well.

General guidelines for managing fluids used and generated during drilling, completion, and testing of UGTA wells are provided in the UGTA Fluid Management Plan, Revision 3 (FMP)

(DOE/NV, 2002a), an attachment to the UGTA Waste Management Plan (DOE/NV, 2002b).

Estimates of expected production of fluid and drill cuttings for the Yucca Flat holes are given in Appendix F of the drilling and completion criteria document for the Yucca Flat drilling project (IT, 
2002), along with sampling requirements and contingency plans for management of any hazardous waste produced. All activities were conducted according to the BN FAWP number 010-002.03 (BN, 2002) and the UGTA Project Health and Safety Plan (BN, 2001).

This report presents construction data and summarizes scientific data gathered during drilling of Well ER-12-2. Some of the information in this report is preliminary and unprocessed, but is being released with the drilling and completion data for convenient reference. A well data report prepared by Shaw (Shaw, 2003) contains additional information on fluid management, waste management, and environmental compliance. Updated geologic information (including any changes in the geologic interpretation) will be compiled in the documentation package for the Yucca Flat hydrostratigraphic framework model to be prepared by BN. Information on well development, aquifer testing, and groundwater analytical sampling will be compiled and disseminated separately, as it is acquired.

\subsection{Objectives}

The overall purpose of constructing Well ER-12-2 is to obtain information that will help characterize the hydrogeology of the northwestern portion of Yucca Flat. The primary scientific objectives for the well, as discussed in the drilling criteria document (IT, 2002), include the following:

- Obtain data to better constrain the extent and thickness of pre-Tertiary hydrostratigraphic units (HSUs), including the lower carbonate aquifer - upper thrust plate (LCA3) and the upper clastic confining unit (UCCU).

- Obtain data that will aid in the characterization of structural features such as the CP thrust fault.

- Obtain hydrologic properties of the HSUs penetrated.

- Obtain initial aqueous geochemistry samples from the lower carbonate aquifer (LCA) for water chemistry and age determinations.

- Obtain data to refine knowledge of the vertical head distribution/vertical hydraulic gradient within the UCCU and between the UCCU and LCA.

- Obtain data for determining horizontal conductivity.

See discussions in Section 4.0 for more information on the HSUs mentioned above. 
Some of these objectives were based on the assumption that Well ER-12-2 would penetrate completely through the UCCU and into the underlying LCA. As discussed in following sections of this report, the well reached total depth (TD) in UCCU, never reaching the LCA. Therefore, some of the scientific objectives will not be met as anticipated. Also, some other objectives will not be met until additional work, beyond the scope of this report, is completed, including installing a pump and conducting hydraulic testing.

\subsection{Project Summary}

This section summarizes Well ER-12-2 construction operations; the details are provided in Sections 2.0 through 8.0 of this report.

The surface conductor hole was constructed by augering a 121.9-centimeter (cm) (48-inch [in.]) diameter hole to a depth of $36.3 \mathrm{~m} \mathrm{(119} \mathrm{ft)} \mathrm{and} \mathrm{installing} \mathrm{a} \mathrm{string} \mathrm{of} \mathrm{30-in.} \mathrm{conductor} \mathrm{casing} \mathrm{to} 35.6 \mathrm{~m}$ (116.8 ft). Drilling of the main hole with an 181/2-in. rotary bit, using an air-water-foam fluid (with a polymer additive as required) in conventional circulation, began on November 20, 2002. A suitable depth to set the surface casing was reached at $613.0 \mathrm{~m}(2,011 \mathrm{ft})$, as planned, and drilling was suspended for geophysical logging prior to installing the casing. Three attempts to log the hole failed because of obstructions in the borehole caused by borehole instability. Attempts to stabilize the hole by cleaning and conditioning the borehole and adding high viscosity mud were unsuccessful, so the diameter of the hole was opened to $66.0 \mathrm{~cm}$ (26 in.) to a depth of $247.2 \mathrm{~m}(811 \mathrm{ft})$ for installation of a 20-in. surface casing. The surface casing was set at $246.9 \mathrm{~m} \mathrm{(810} \mathrm{ft)}$ and cemented in place on December 1, 2002.

A piezometer string consisting of $2 \mathrm{~d}$-in. slotted tubing was installed between the borehole wall and the 20-in. casing to provide access to water-producing horizons noted during drilling at $166.4 \mathrm{~m}$ (546 ft). The bottom of the monitoring string was placed at $176.4 \mathrm{~m}(578.9 \mathrm{ft})$ after encountering an obstruction at that depth.

After the surface casing and piezometer string were installed, an 181/2-in. bottom hole assembly (BHA) was lowered into the hole to clean it out and continue drilling below $613.0 \mathrm{~m}(2,011 \mathrm{ft})$. However, continued borehole instability necessitated the addition of bentonite mud to stabilize the hole. After the hole was cleaned out to $613.0 \mathrm{~m}$ (2,011 ft), drilling with the 181/2-in. BHA and bentonite mud resumed on December 7, 2002. On December 16, 2002, drilling was suspended at a depth of $903.4 \mathrm{~m}$ 
$(2,964 \mathrm{ft})$ for installation of a string of $13 \mathrm{~d}$-in. intermediate casing. The casing was set at a depth of $901.6 \mathrm{~m}(2,958 \mathrm{ft})$ and cemented in place on December 21, 2002. The remainder of the hole was drilled with a 121/4-in. bit using air-foam from $903.4 \mathrm{~m}(2,964)$ to a total depth (TD) of 2,097.9 m $(6,883 \mathrm{ft})$, which was reached on January 15, 2003.

Composite drill cuttings were collected every $3 \mathrm{~m}$ (10 ft) from $36.6 \mathrm{~m}$ (120 ft) to TD, and 7 sidewall core samples were taken at various depths between 790.7 and 1,208.8 m (2,594 and 3,966 ft). Open-hole geophysical logging of the well was conducted to help verify the geology and characterize the hydrologic properties of the rocks; some logs also aided in the construction of the well by indicating borehole volume and condition. The well penetrated, in descending order, $137.2 \mathrm{~m}$ (450 ft) of alluvium, $48.8 \mathrm{~m}$ (160 ft) of welded and nonwelded tuff older than the Timber Mountain Group, $289.6 \mathrm{~m}$ (950 ft) of Mississippian Chainman Shale, and 1,622.5 m (5,323 ft) of Mississippian and Upper Devonian Eleana Formation.

The well was not completed as planned because the target hydrogeologic unit (i.e., LCA) was not encountered. The only completion string installed in the well is the $2 \mathrm{~d}$-in. piezometer string set at $176.4 \mathrm{~m}(578.9 \mathrm{ft})$.

\title{
1.4 Project Manager
}

Inquiries concerning Well ER-12-2 should be directed to the UGTA Project Manager at:

\author{
U.S. Department of Energy \\ National Nuclear Security Administration \\ Nevada Site Office \\ Environmental Restoration Division \\ Post Office Box 98518 \\ Las Vegas, Nevada 89193-8518
}




\subsection{Drilling Summary}

\subsection{Introduction}

This section contains detailed descriptions of the drilling process and fluid management issues. The general drilling requirements for all FY 2003 Yucca Flat wells were provided in Yucca Flat Hydrogeologic Investigation Wells Drilling and Completion Criteria (IT, 2002). Specific requirements for Well ER-12-2 were outlined in FAWP number 002-002.03 (BN, 2002). Figure 2-1 shows the layout of the drill site. Figure 2-2 is a chart of the drilling and completion history for Well ER-12-2. A summary of drilling statistics for the well is given in Table 2-1. The following information was compiled primarily from $\mathrm{BN}$ daily drilling reports.

\subsection{Drilling History}

Field operations at Well ER-12-2 began on October 23, 2002, when BN drillers using an auger rig drilled a 121.9-cm (48-in.) diameter conductor hole to the depth of $36.3 \mathrm{~m}$ (119 ft). A string of 30-in. conductor casing was set at the depth of $35.6 \mathrm{~m}$ (116.8 ft). The bottom of the conductor casing was

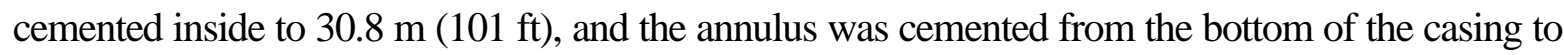
ground level on October 29, 2002.

The UDI crews rigged up the Wilson Mogul 42B Double Drum Rig Number 5 on November 15 to 20, 2002. Drilling resumed through the cement at the bottom of the 30-in. casing with a center-punch assembly consisting of an 181/2-in. rotary bit mounted below a 26-in. hole opener using air, water, and foam ("air-foam") in conventional circulation. When the $181 / 2$-in. bit reached a depth of

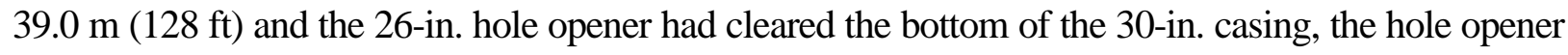
was removed and drilling of the 47.0-cm (18.5-in.) hole resumed.

Drilling of the main hole with an 181/2-in. rotary bit and air-foam began November 21, 2002. The first water production was noted by Shaw personnel on November 22, 2002, at a depth of $166.4 \mathrm{~m}$ $(546 \mathrm{ft})$. The borehole was advanced to a depth of $613.0 \mathrm{~m}$ (2,011 ft) on November 25, 2002, which was near the planned casing point for a $13 \mathrm{~d}$-in. surface casing. The drillers circulated the air-foam system to clean and condition the hole, pulled the drill string off the bottom, and waited about 30 minutes before lowering the drill string to $609.6 \mathrm{~m}$ (2,000 ft) without encountering any fill or other obstructions. As the drill string was pulled out of the hole for geophysical logging operations prior to running the casing, tight spots were encountered at $426.7 \mathrm{~m}(1,400 \mathrm{ft})$ and $129.8 \mathrm{~m}(426 \mathrm{ft})$. 


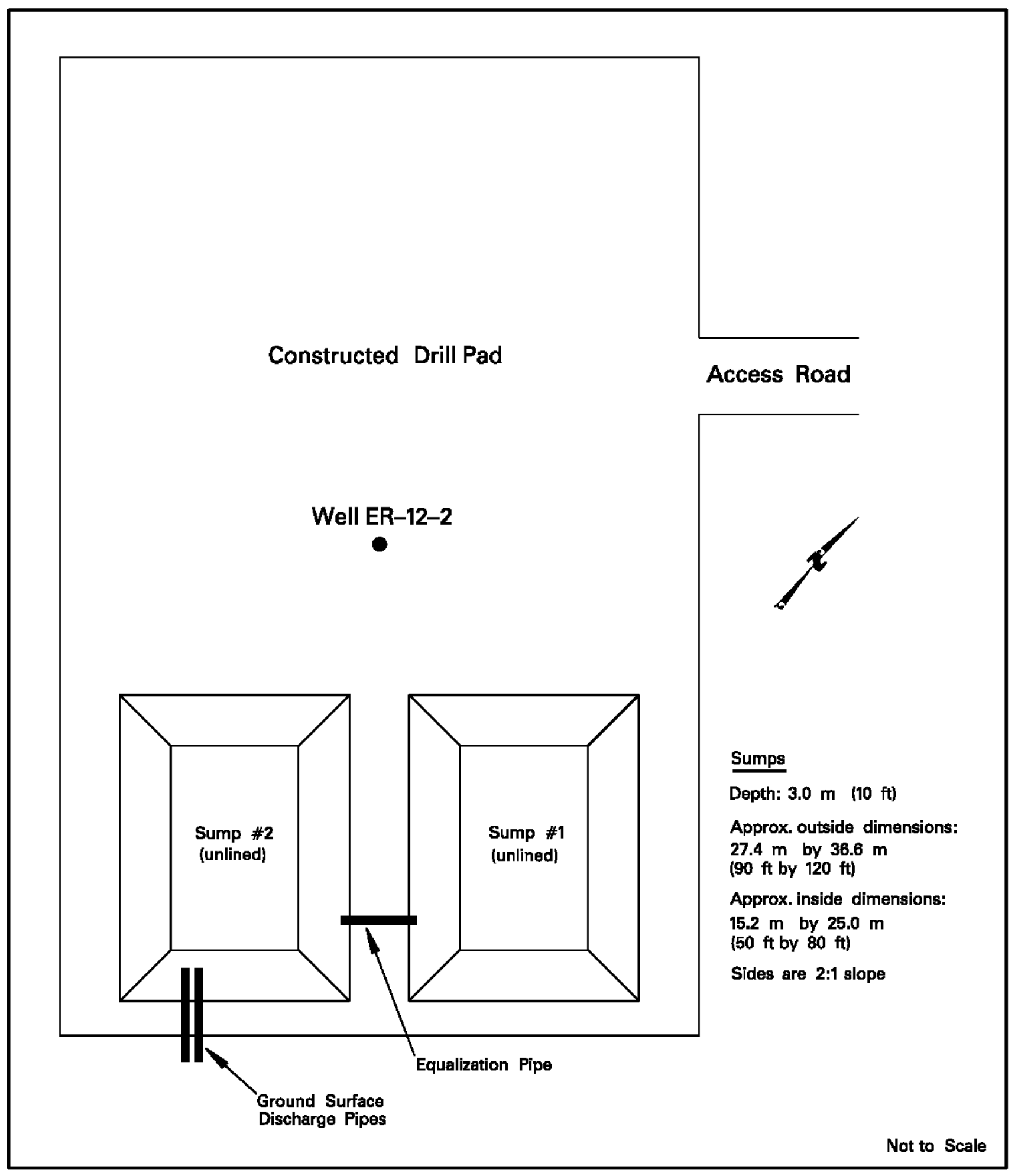

Figure 2-1

Drill Site Configuration for Well ER-12-2 


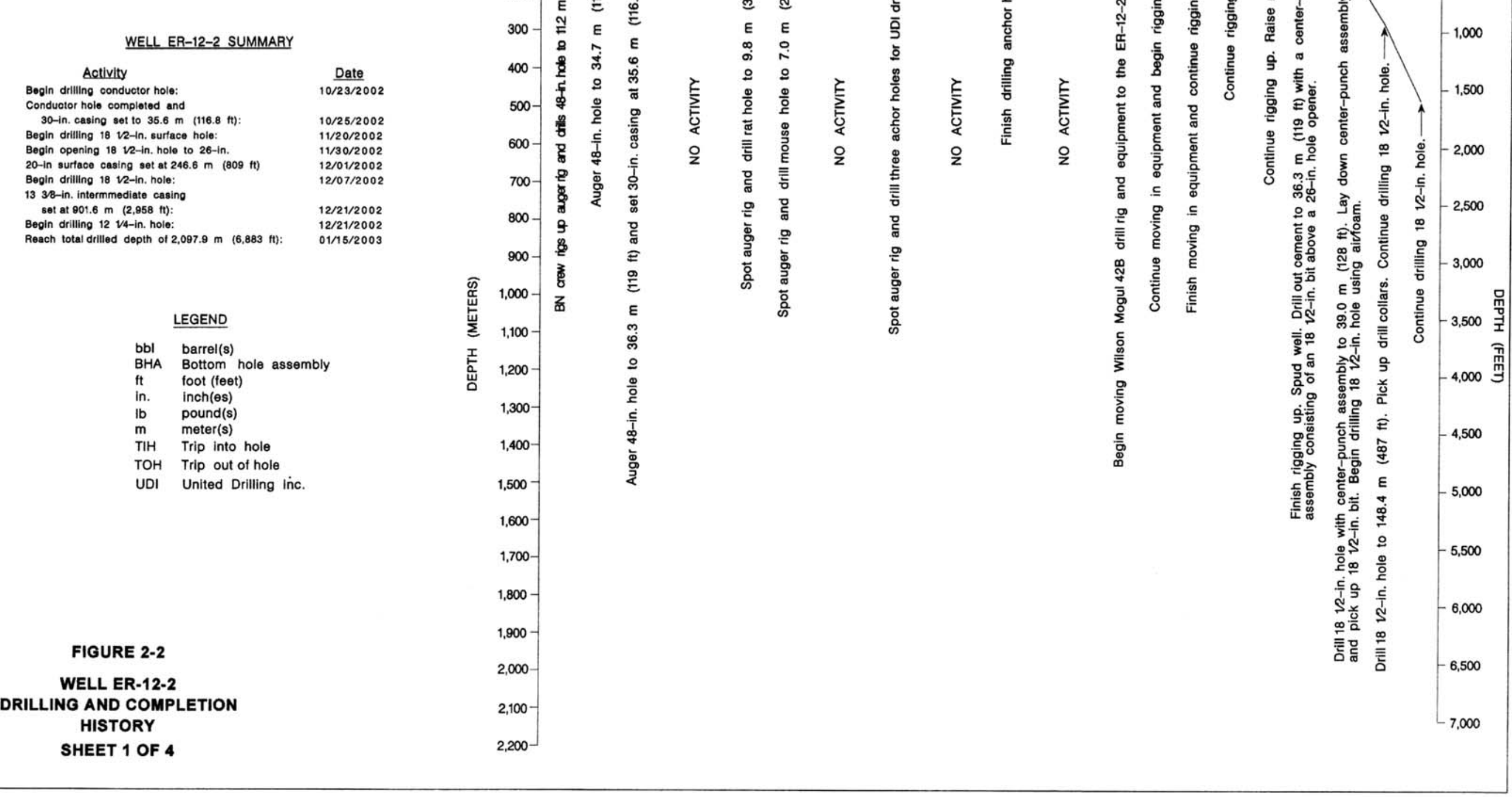




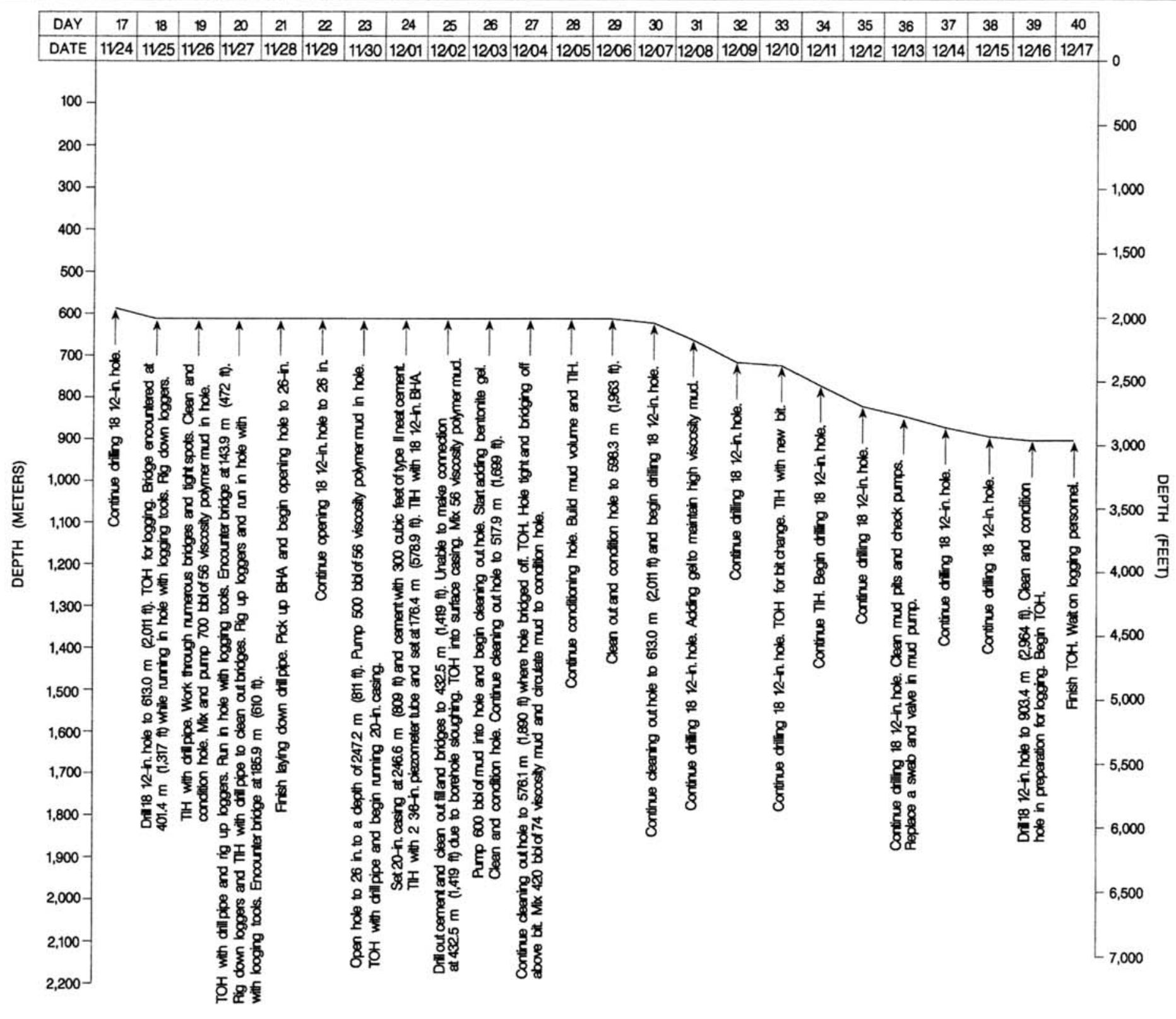

FIGURE 2-2

WELL ER-12-2

DRILLING AND COMPLETION

HISTORY

SHEET 2 OF 4 


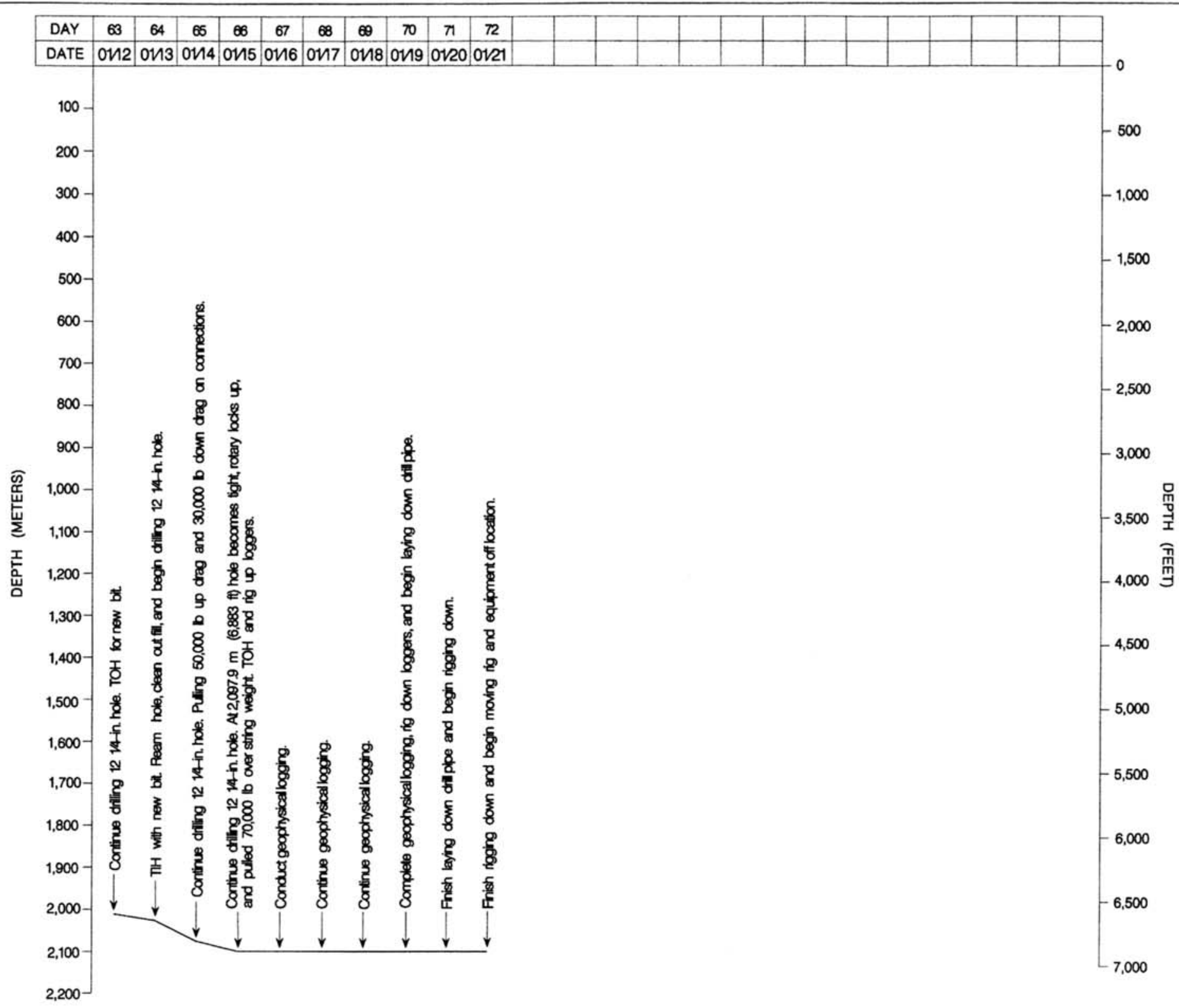

FIGURE 2-2

WELL ER-12-2

DRILLING AND COMPLETION

HISTORY

SHEET 4 OF 4 


\section{Table 2-1}

\section{Abridged Drill Hole Statistics for Well ER-12-2}

\begin{tabular}{|c|c|c|c|c|}
\hline \multirow[t]{2}{*}{$\begin{array}{l}\text { LOCATION DATA: } \\
\text { Coordinates: }\end{array}$} & Nevada State Plane (central zone): & \multirow{2}{*}{$\begin{array}{l}\text { NAD 83: } \\
\text { NAD 27: } \\
\text { NAD 83: }\end{array}$} & \multirow{2}{*}{$\begin{array}{l}\text { N 6,268,794.1 m } \\
\text { N } 881,865.4 \mathrm{ft} \\
\text { N } 4,114,254.6 \mathrm{~m}\end{array}$} & \multirow{2}{*}{$\begin{array}{l}\text { E } 548,245.2 \mathrm{~m} \\
\text { E } 658,542.7 \mathrm{ft} \\
\text { E } 577,823.3 \mathrm{~m}\end{array}$} \\
\hline & Universal Transverse Mercator: & & & \\
\hline Surface Elevation ${ }^{\text {a: }} \quad 1$ & \multicolumn{4}{|l|}{$1,434.2 \mathrm{~m}(4,705.3 \mathrm{ft})$} \\
\hline \multicolumn{5}{|l|}{$\begin{array}{l}\text { DRILLING DATA: } \\
\text { Spud Date: }\end{array}$} \\
\hline Total Depth (TD): & \multicolumn{4}{|l|}{$2,097.9 \mathrm{~m}(6,883 \mathrm{ft})$} \\
\hline Date TD Reached: & \multicolumn{4}{|l|}{$01 / 15 / 2003$} \\
\hline Date Well Completed: & \multicolumn{4}{|c|}{ Piezometer tube installed on 12/01/2002. } \\
\hline Hole Diameter: & \multicolumn{4}{|c|}{ 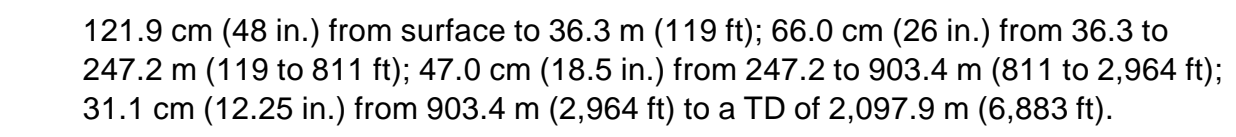 } \\
\hline Drilling Techniques: & \multicolumn{4}{|c|}{$\begin{array}{l}\text { Dry-hole auger from surface to } 36.3 \mathrm{~m} \text { ( } 119 \mathrm{ft}) \text {; rotary drilling with } 181 / 2 \text {-in. tricone } \\
\text { bit using air-foam and polymer in direct circulation from } 36.3 \text { to } 613.0 \mathrm{~m} \\
\text { ( } 119 \text { to } 2,011 \mathrm{ft}) \text {; rotary drilling with } 26 \text {-in. hole opener above } 181 / 2-\text {-in. bit using } \\
\text { air-foam and polymer in direct circulation from } 36.3 \text { to } 247.2 \mathrm{~m}(119 \text { to } 811 \mathrm{ft}) \text {; } \\
\text { rotary drilling with } 18^{1 / 2} \text {-in. tricone bit using bentonite gel in direct circulation from } \\
613.0 \text { to } 903.4 \mathrm{~m}(2,011 \text { to } 2,964 \mathrm{ft}) \text {; rotary drilling with } 12^{1 / 4}-\mathrm{in} \text {. tricone bit using } \\
\text { air-foam and polymer in direct circulation from } 903.4 \mathrm{~m}(2,964 \mathrm{ft}) \text { to a TD of } \\
2,097.9 \mathrm{~m}(6,883 \mathrm{ft}) \text {. }\end{array}$} \\
\hline CASING DATA: & \multicolumn{4}{|c|}{$\begin{array}{l}\text { 30-in. conductor casing, surface to } 35.6 \mathrm{~m}(116.8 \mathrm{ft}) ; 20 \text {-in. surface casing, } \\
\text { surface to } 246.6 \mathrm{~m}(809 \mathrm{ft}) ; 13 \mathrm{~d} \text {-in. intermediate casing, surface to } 901.6 \mathrm{~m} \\
(2,958 \mathrm{ft}) .\end{array}$} \\
\hline \multicolumn{5}{|c|}{$\begin{array}{l}\text { WELL COMPLETION DATA: } \\
\text { Piezometer string consisting of } 2 \mathrm{~d} \text {-in. carbon-steel tubing was installed outside the } 20 \text {-in. surface casing. } \\
\text { The inside diameter of the tubing is } 4.94 \mathrm{~cm}(1.945 \mathrm{in} \text {.) and the outside diameter is } 6.03 \mathrm{~cm}(2.375 \mathrm{in} .) \text {. }\end{array}$} \\
\hline \multicolumn{5}{|c|}{ Piezometer Total Depth: $176.4 \mathrm{~m}(578.9 \mathrm{ft})$} \\
\hline \multicolumn{5}{|c|}{ Depth of Slotted Section: 141.1 to $176.4 \mathrm{~m}$ (463.0 to $578.9 \mathrm{ft}$ ) } \\
\hline \multicolumn{5}{|c|}{ Gravel/Sand Pack: $\quad$ None } \\
\hline Top of fill: & \multicolumn{4}{|l|}{$2,097.6 \mathrm{~m}(6,882 \mathrm{ft})$ on $01 / 16 / 2003$} \\
\hline Water Depth ${ }^{\mathrm{b}}$ : & \multicolumn{4}{|c|}{$\begin{array}{l}65.43 \mathrm{~m}(214.67 \mathrm{ft}) \text { in the open borehole } \\
127.14 \mathrm{~m}(417.13 \mathrm{ft}) \text { in the piezometer }\end{array}$} \\
\hline \multicolumn{5}{|l|}{ DRILLING CONTRACTOR: } \\
\hline GEOPHYSICAL LOGS BY: & \multicolumn{4}{|c|}{ Halliburton Energy Services; Desert Research Institute; Baker-Hughes Inteq } \\
\hline SURVEYING CONTRACTOR & Bechtel Nevada & & & \\
\hline
\end{tabular}

a Elevation of ground level at wellhead. 1929 National Geodetic Vertical Datum.

b Measured by Shaw on March 3, 2003 (Shaw, 2003). 
Halliburton Energy Services (HES) rigged up to conduct the planned geophysical logging. However, the loggers encountered a bridge of sloughed material at $401.4 \mathrm{~m}(1,317 \mathrm{ft})$ while lowering the tool into the hole, and tight spots while logging out of the hole. The drillers lowered the BHA into the borehole to clean it out, encountering numerous bridges and tight spots. After reaching the bottom of the hole at

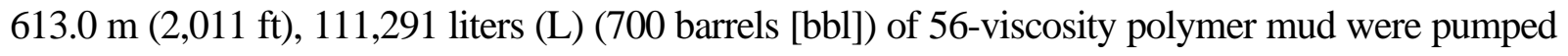
into the hole to stabilize the hole for logging. A second attempt at logging was stopped by another bridge at $143.9 \mathrm{~m}$ (472 ft). The drill string was again lowered into the hole to clean out bridges to a depth of $178.0 \mathrm{~m}(584 \mathrm{ft})$. A 12,719-L (80-bbl) slug of mud was placed in the hole from 158.8 to $178.0 \mathrm{~m}$ (521 to $584 \mathrm{ft}$ ) to stabilize that portion of the hole and the logging tools were again lowered in the hole but encountered another bridge at $185.9 \mathrm{~m}(610 \mathrm{ft})$.

After the logging attempts, it was decided to install a surface casing to seal off the unstable portion of the hole above $243.8 \mathrm{~m}$ (800 ft). The larger diameter 20-in. casing (rather than 13d -in. casing) was chosen to assure that a large enough diameter hole would be available at the planned TD, if it became necessary to install additional strings of casing as drilling proceeded. A BHA consisting of an 181/2-in. bit with a 26-in. hole opener was used to enlarge the hole in preparation for running 20 -in. casing. The $47.0-\mathrm{cm}$ (18.5-in.) hole was opened to $66.0 \mathrm{~cm}$ (26 in.) to a depth of $247.2 \mathrm{~m} \mathrm{(811} \mathrm{ft)} \mathrm{and} \mathrm{the} \mathrm{casing}$ was run into the hole to a depth of $246.9 \mathrm{~m}(810 \mathrm{ft})$. The bottom of the casing was cemented with 8.5 cubic meters $\left(\mathrm{m}^{3}\right)$ (300 cubic feet $\left.\left[\mathrm{ft}^{3}\right]\right)$ of Type II neat cement on December 1, 2002.

A monitor string consisting of $2 \mathrm{~d}$-in. tubing was lowered into the hole between the borehole wall and the 20-in. casing to provide access to water producing horizons noted during drilling at $166.4 \mathrm{~m}$ $(546 \mathrm{ft})$. The bottom of the monitoring string was placed at $176.4 \mathrm{~m}(578.9 \mathrm{ft})$ after encountering an obstruction at that depth.

After installation of the casing and monitoring string, the BHA was lowered into the hole to drill out the cement and clean out the hole to $613.0 \mathrm{~m}(2,011 \mathrm{ft})$. The top of cement inside the 20 -in. casing was tagged at $245.4 \mathrm{~m}(805 \mathrm{ft})$, and the cement was drilled out to $246.9 \mathrm{~m}(810 \mathrm{ft})$ using air-foam and polymer. Fill material was cleaned out of the hole to a depth of $432.5 \mathrm{~m}(1,419 \mathrm{ft})$, but continued sloughing of the borehole wall and the accumulation of fill prevented making the next connection. The drill string was raised into the surface casing so that the circulation system could be switched from airfoam to mud to achieve better borehole stability. 
After pumping a slug of 95,392 L (600 bbl) of 56-viscosity polymer mud into the hole, the drillers lowered the drill string back into the hole and cleaned it out to $508.4 \mathrm{~m}$ (1,668 ft). However, sloughing and tight hole conditions persisted, necessitating the addition of bentonite gel to the mud system. Continued borehole instability problems, including tight hole conditions and bridging above the bit, plagued operations as the hole was cleaned out to a depth of $576.1 \mathrm{~m}(1,890 \mathrm{ft})$. The viscosity of the mud was increased by the addition of $66,775 \mathrm{~L}$ ( $420 \mathrm{bbl})$ of 74-viscosity mud in the continuing effort to improve hole stability. After circulating the mud to condition the hole, and building mud volume, the drillers cleaned out the hole to $613.0 \mathrm{~m}(2,011 \mathrm{ft})$. They pulled the drill string up to $353.6 \mathrm{~m}(1,160 \mathrm{ft})$ and then lowered it, encountering the top of $14.0 \mathrm{~m}(46 \mathrm{ft})$ of fill at $596.2 \mathrm{~m}(1,956 \mathrm{ft})$. The hole was again cleaned out to $613.0 \mathrm{~m}(2,011 \mathrm{ft})$ and drilling of the 47.0-cm (18.5-in.) hole resumed on

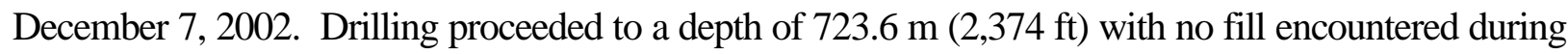
connections, and at that point a new 181/2-in. bit was installed.

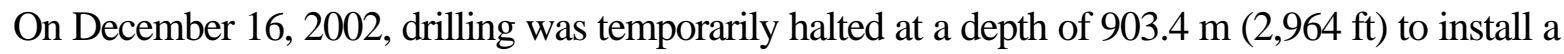
string of $13 d$-in. casing. Installation of this intermediate casing was necessary to seal off unstable portions of the borehole and allow switching back to an air-foam circulating system to improve penetration rate, which had slowed to less than 1.5 meters per hour $(\mathrm{m} / \mathrm{hr})(5$ feet per hour $[\mathrm{ft} / \mathrm{hr}])$ below $853.4 \mathrm{~m}(2,800 \mathrm{ft})$, and because air-foam is the desired circulating fluid for drilling the lower carbonate aquifer, which was anticipated to be encountered within a few hundred feet. Geophysical logging was conducted on December 18 and 19, 2002, then the 13d -in. casing was lowered into the hole to a depth of $901.6 \mathrm{~m}$ (2,958.2 ft) and the bottom cemented with $9.9 \mathrm{~m}^{3}\left(350 \mathrm{ft}^{3}\right)$ of Type II neat cement. The bentonite mud was displaced from the borehole and the circulating system changed to an air-foam/polymer mix. Cement was drilled out with a 121/4-in. bit from 887.9 to $902.2 \mathrm{~m}(2,913$ to 2,960 ft) and fill was cleaned out to $903.4 \mathrm{~m}(2,964 \mathrm{ft})$.

Drilling of a 31.1-cm (12.25-in.) hole began on December 21, 2002, and proceeded from 903.4 to $1,020.8 \mathrm{~m}(2,964$ to $3,349 \mathrm{ft})$ where the rate of penetration again slowed to $1.5 \mathrm{~m} / \mathrm{hr}(5 \mathrm{ft} / \mathrm{hr})$. Increasing torque on the drill string was noted, and metal shavings were found in the drill cuttings samples, so the drill string was pulled from the hole for inspection. Examination of the BHA revealed extensive wear to the bit and reamers. Drilling operations were suspended on December 23, 2002, for the holiday.

Drilling operations resumed on December 27, 2002, with a new 121/4-in. bit. The hole had to be reamed from 944.9 to $1,020.8 \mathrm{~m}$ (3,100 to $3,349 \mathrm{ft})$ because it was under gauge from using the worn 
bit. A 31.1-cm (12.25-in.) hole was drilled from 1,020.8 to 1,203.0 m (3,349 to 3,947 ft), at which depth the drill string was removed from the hole to inspect the bit. The bit again showed extensive wear and was replaced.

Drilling with a 121/4-in. bit resumed at 1,203.0 $\mathrm{m}(3,947 \mathrm{ft})$ after reaming under-gauge hole from 1,187.2 to $1,203.0 \mathrm{~m}(3,895$ to $3,947 \mathrm{ft})$. Drilling continued to the depth of 2,097.9 $\mathrm{m}(6,883 \mathrm{ft})$ but was very slow and required 4 bit changes due to excessive wear of the bits caused by the hard, abrasive quartzite being drilled. Drilling was terminated on January 15, 2003, at a depth of 2,097.9 m $(6,883 \mathrm{ft})$. At this point, the hole had become tight, causing the rotary table to lock up, and a drag of 31,752 kilograms (70,000 pounds) over drill string weight was encountered when pulling the bit off bottom. The drill string was removed from the hole and logging operations were conducted on January 16 to 19, 2003. The drillers rigged down the drilling equipment on January 20 and 21, 2003, and then began to move the drilling equipment to the Well ER-7-1 site.

A graphical depiction of drilling parameters including penetration rate, rotary revolutions per minute, pump pressure, and weight on the bit is presented in Appendix A-1. See Appendix A-2 for a listing of casing materials. Drilling fluids and cements used in Well ER-12-2 are listed in Appendix A-3.

The directional survey run in the borehole on April 15, 2003, indicates that at the lowest surveyed depth of 2,092.5 $\mathrm{m}(6,865 \mathrm{ft})$, the hole had drifted $609.6 \mathrm{~m}(2,000 \mathrm{ft})$ north-northeast of the surface location. The maximum deviation of 56.77 degrees off vertical occurred at the measured depth of $1,869.5 \mathrm{~m}(6,133.5 \mathrm{ft})$. This deviation resulted in a true vertical hole depth of 1,896.2 $\mathrm{m}(6,221 \mathrm{ft})$ versus a measured (drilled) depth of 2,097.9 m (6,883 ft).

\subsection{Drilling Problems}

Borehole instability in the upper portions of the hole resulted in difficult drilling conditions above the depth of approximately $609.6 \mathrm{~m}$ (2,000 ft). Sloughing of the borehole wall and intervals of swelling clays in the formation caused accumulation of fill material during connections, tight spots, and bridges, which necessitated numerous borehole cleaning and conditioning efforts, opening the hole from 47.0 to

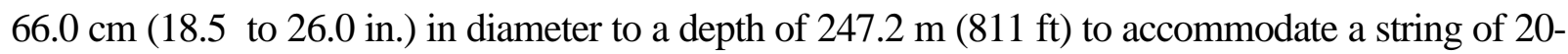
in. surface casing, and using high viscosity mud as a circulating fluid while drilling from 613.0 to $903.4 \mathrm{~m}$ $(2,011$ to $2,964 \mathrm{ft})$. 


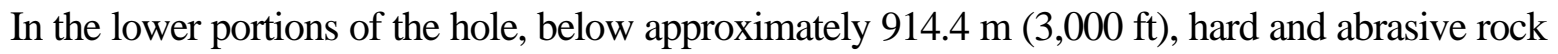
slowed drilling rates considerably and caused extensive wear to some of the components of the BHA, which required 6 drill bit changes during drilling from 903.4 to 2,097.9 $\mathrm{m}$ (2,964 to 6,883 ft). The severe deviation of the borehole also probably contributed to the excessive wear of the BHA.

\section{$2.4 \quad$ Fluid Management}

Drilling effluent was monitored according to the methods prescribed in the UGTA FMP (DOE/NV, 2002) and the associated state-approved, well-specific, fluid management strategy letter (Wycoff, 2002). The air-foam/polymer drill fluid was circulated down the inside of the drill string and back up the hole through the annulus (conventional or direct circulation) and then discharged into a sump. The bentonite mud drill fluid was also conventionally circulated, but was contained and re-circulated during drilling, and not discharged to the sump until mud-based drilling operations were complete. Water used to prepare drilling fluids came from Well UE-16d, located in western Yucca Flat. Lithium bromide $(\mathrm{LiBr})$ was added to the drill fluid as a tracer to provide a means of estimating groundwater production. The rate of water inflow was estimated from the dilution of the tracer in the drill fluid returns.

To manage the anticipated water production, two sumps were constructed prior to drilling (Figure 2-1). No contaminants were expected during drilling at this site, so neither sump was lined. Samples of drilling effluent were collected hourly and analyzed on site by BN Radiation Operations personnel for the presence of tritium. The onsite monitoring results indicate that tritium levels measured in the drilling fluid remained at or below background levels, ranging from 0 to 3,262 picocuries per liter. Drilling fluids generated at Well ER-12-2 were not analyzed for lead, according to the Well ER-12-2 Fluid Management Strategy Letter (Shaw, 2002).

No samples of drilling fluid were collected from the sumps at Well ER-12-2 for water quality analyses during drilling operations. Because of the low volume of fluids produced during drilling, it was not necessary to discharge fluid to the ground surface. However, all fluid quality objectives were met, as shown on the fluid management reporting form dated July 18, 2003 (Appendix B). The form lists volumes of solids (drill cuttings) and fluids produced during well-construction operations (vadose- and saturated-zone drilling only; well development and aquifer testing will be conducted at a later date). The volume of solids produced was calculated using the diameter of the borehole (from caliper logs) and the depth drilled, and includes added volume attributed to a rock bulking factor. The volumes of fluids listed on the report are estimates of total fluid production, and do not account for any infiltration or evaporation of fluids from the sumps. 
This page intentionally left blank. 


\subsection{Geologic Data Collection}

\subsection{Introduction}

This section describes the sources of geologic data obtained from Well ER-12-2 and the methods of data collection. Improving the understanding of the subsurface structure, stratigraphy, and hydrogeology in the northwestern portion of Yucca Flat was among the primary objectives of Well ER-12-2, so the proper collection of geologic and hydrogeologic data from Well ER-12-2 was considered fundamental to successful completion of the project.

Geologic data collected at Well ER-12-2 consist of drill cuttings, sidewall core samples, and geophysical logs. Data collection, sampling, transfer, and documentation activities were performed according to applicable contractor procedures.

\subsection{Collection of Drill Cuttings}

Composite drill cuttings were collected from Well ER-12-2 at 3-m (10-ft) intervals as drilling progressed from the depth of $36.6 \mathrm{~m}$ (120 ft) (bottom of the conductor hole) to the TD of the well at 2,097.9 m (6,883 ft). Triplicate samples, each consisting of approximately 550 cubic centimeters of material, were collected from 670 intervals. These samples are stored under environmentally controlled, secure conditions at the U.S. Geological Survey (USGS) Geologic Data Center and Core Library in Mercury, Nevada. One of these sample sets was sealed with custody tape at the rig site and remains sealed as an archive sample; one set was left unsealed in the original sample containers; and the third set was washed and stored according to standard USGS Core Library procedures. The washed set was used by $\mathrm{BN}$ to construct the detailed lithologic log presented in Appendix C. The Shaw Field Representative collected an additional two sets of reference drill cuttings samples from each of the cuttings intervals. One set was examined at the drill site for use in preparing field lithologic descriptions, and remains in the custody of Stoller-Navarro Joint Venture (Shaw's successor and the current environmental contractor for NNSA/NSO) in Las Vegas, Nevada. The other set was sent to Giday WoldeGabriel at LANL in New Mexico for petrographic, mineralogic, and chemical analyses, where it remains. In addition, 3.8 liters (1 gallon) of composite drill cuttings samples were collected at 15.2-m (50-ft) intervals while drilling the pre-Tertiary section. These samples were collected for paleontologic analysis, and are also stored at the USGS Geologic Data Center and Core Library in Mercury, Nevada. 


\subsection{Sidewall Core Samples}

Sidewall core samples were collected by HES from Well ER-12-2 to verify the stratigraphy and lithology at selected locations. Both percussion-gun and rotary sidewall coring tools were utilized. Sample locations were selected by the Shaw Field Representative on the basis of field lithologic logs, with consideration of borehole conditions determined from caliper logs. The percussion gun tool was used to collect core samples between the depths of 696.5 and 1,215.5 m (2,285 and 3,988 ft). A total of 48 sample depths were attempted, with 6 cores recovered. The rotary sidewall coring tool was used to collect sidewall cores from 960.1 to $2,090.9 \mathrm{~m} \mathrm{(3,150}$ to $6,860 \mathrm{ft}$ ). Only 1 core was recovered in 25 attempts. Table 3-1 summarizes the results of sidewall coring operations at Well ER-12-2.

\subsection{Sample Analysis}

Twenty-five samples of drill cuttings from various depths in Well ER-12-2 were submitted to the Hydrology, Geochemistry, and Geology Group of the Earth and Environmental Sciences Division at LANL for petrographic, mineralogic, and chemical analyses to aid in stratigraphic identification and for characterization of mineral alteration. Table 3-2 lists the sample depths and the status of laboratory analyses.

\subsection{Geophysical Log Data}

Geophysical logs were run in the borehole to further characterize the lithology, structure, and hydrologic properties of the rocks encountered, and to evaluate borehole conditions. Geophysical logging was conducted in three stages during drilling: prior to setting the 20-in. surface casing at $246.6 \mathrm{~m}$ (809 ft), prior to installing the $13 \mathrm{~d}$-in. intermediate casing at $901.6 \mathrm{~m}(2,958 \mathrm{ft})$, and at the TD of the hole at $2,097.9 \mathrm{~m}(6,883 \mathrm{ft})$. A complete listing of the logs, dates run, depths, and service companies is provided in Table 3-3. The logs are available from BN in Mercury, Nevada, and copies are on file at the office of Stoller-Navarro Joint Venture in Las Vegas, Nevada, and at the USGS Geologic Data Center and Core Library in Mercury, Nevada. Preliminary geophysical data from the logs are reproduced in Appendix D. 
Table 3-1

Sidewall Samples from Well ER-12-2

\begin{tabular}{|c|c|c|c|c|c|c|c|}
\hline \multicolumn{2}{|c|}{$\begin{array}{c}\text { Core Depth } \\
\text { Meters (Feet) } \\
\end{array}$} & $\begin{array}{l}\text { Tool } \\
\text { Used }^{\text {a }} \\
\end{array}$ & \multicolumn{2}{|c|}{$\begin{array}{c}\text { Recovery } \\
\text { Centimeters (Inches) } \\
\end{array}$} & Formation & Lithology & Comments \\
\hline 790.7 & $(2,594)$ & SWC & 3.4 & $(1.3)$ & Eleana Formation & Argillite & $\begin{array}{l}\text { Mostly wall-cake } \\
\text { with argillite } \\
\text { fragments. }\end{array}$ \\
\hline 798.6 & $(2,620)$ & SWC & 2.0 & $(0.8)$ & Eleana Formation & Argillite & -- \\
\hline 919.9 & $(3,018)$ & SWC & 1.0 & $(0.4)$ & Eleana Formation & Quartzite & $\begin{array}{l}\text { Core is highly } \\
\text { shattered. }\end{array}$ \\
\hline 932.4 & $(3,059)$ & SWC & 1.5 & $(0.6)$ & Eleana Formation & Argillite & -- \\
\hline 960.1 & $(3,150)$ & RSWC & 3.0 & $(1.2)$ & Eleana Formation & Quartzite & -- \\
\hline $1,164.0$ & $(3,819)$ & SWC & 3.0 & $(1.2)$ & Eleana Formation & Shale & -- \\
\hline $1,208.8$ & $(3,966)$ & SWC & 3.5 & $(1.4)$ & Eleana Formation & Shale & -- \\
\hline
\end{tabular}

a $\quad$ SWC $=$ percussion-gun sidewall coring tool; $R S W C=$ rotary sidewall coring tool. 
Table 3-2

Status of Rock Sample Analyses for Well ER-12-2

\begin{tabular}{|c|c|c|c|c|c|c|}
\hline \multirow{3}{*}{$\begin{array}{c}\text { Depth }^{\text {a }} \\
\text { meters (feet) }\end{array}$} & \multirow{3}{*}{$\begin{array}{l}\text { Sample } \\
\text { Type }^{\text {b }}\end{array}$} & \multicolumn{5}{|c|}{ Analyses Performed $^{c}$} \\
\hline & & \multirow{2}{*}{$\begin{array}{c}\text { Petrographic } \\
\text { PTS } \\
\end{array}$} & \multicolumn{2}{|c|}{ Mineralogic } & \multicolumn{2}{|c|}{ Chemical } \\
\hline & & & MP & XRD & XRF & $\mathrm{Fe}^{2+} / \mathrm{Fe}^{3+}$ \\
\hline $36.6(120)$ & DC & $\mathrm{C}$ & $\mathrm{NP}$ & $\mathrm{C}$ & $\mathrm{C}$ & $\mathrm{C}$ \\
\hline $48.8(160)$ & DC & $\mathrm{C}$ & $\mathrm{NP}$ & $\mathrm{C}$ & $\mathrm{C}$ & $\mathrm{C}$ \\
\hline $100.6(330)$ & DC & $\mathrm{C}$ & NP & $\mathrm{C}$ & $\mathrm{C}$ & $\mathrm{C}$ \\
\hline $125.0(410)$ & DC & C & NP & $\mathrm{C}$ & C & C \\
\hline $143.3(470)$ & DC & $\mathrm{C}$ & $\mathrm{NP}$ & $\mathrm{C}$ & $\mathrm{C}$ & $\mathrm{C}$ \\
\hline $146.3(480)$ & DC & C & $\mathrm{C}$ & C & NP & NP \\
\hline $152.4(500)$ & $\mathrm{DC}$ & $\mathrm{C}$ & NP & $\mathrm{C}$ & $\mathrm{C}$ & $\mathrm{C}$ \\
\hline $161.5(530)$ & $\mathrm{DC}$ & $\mathrm{C}$ & $\mathrm{C}$ & $\mathrm{C}$ & $\mathrm{C}$ & $\mathrm{C}$ \\
\hline $170.7(560)$ & $\mathrm{DC}$ & $\mathrm{C}$ & C & $\mathrm{C}$ & $\mathrm{C}$ & $\mathrm{C}$ \\
\hline $173.7(570)$ & $\mathrm{DC}$ & $\mathrm{C}$ & $\mathrm{C}$ & $\mathrm{C}$ & $\mathrm{C}$ & $\mathrm{C}$ \\
\hline $179.8(590)$ & DC & C & C & C & C & C \\
\hline $182.9(600)$ & $\mathrm{DC}$ & $\mathrm{C}$ & $\mathrm{NP}$ & $\mathrm{C}$ & C & $\mathrm{C}$ \\
\hline $189.0(620)$ & $\mathrm{DC}$ & C & $\mathrm{C}$ & C & $\mathrm{C}$ & $\mathrm{C}$ \\
\hline $192.0(630)$ & $\mathrm{DC}$ & $\mathrm{C}$ & $\mathrm{NP}$ & $\mathrm{C}$ & C & $\mathrm{C}$ \\
\hline $195.1(640)$ & DC & C & $\mathrm{NP}$ & $\mathrm{C}$ & $\mathrm{C}$ & $\mathrm{C}$ \\
\hline $249.9(820)$ & $\mathrm{DC}$ & $\mathrm{C}$ & $\mathrm{NP}$ & $\mathrm{C}$ & NP & NP \\
\hline $313.9(1,030)$ & DC & $\mathrm{C}$ & $\mathrm{NP}$ & $\mathrm{C}$ & NP & NP \\
\hline $335.3(1,100)$ & $\mathrm{DC}$ & $\mathrm{C}$ & $\mathrm{NP}$ & $\mathrm{C}$ & NP & NP \\
\hline $548.6(1,800)$ & DC & $\mathrm{C}$ & $\mathrm{NP}$ & $\mathrm{C}$ & $\mathrm{NP}$ & NP \\
\hline $859.5(2,820)$ & $\mathrm{DC}$ & $\mathrm{C}$ & NP & $\mathrm{C}$ & NP & NP \\
\hline $914.4(3,000)$ & $\mathrm{DC}$ & $\mathrm{C}$ & $\mathrm{NP}$ & $\mathrm{C}$ & $\mathrm{NP}$ & NP \\
\hline $1,365.5(4,480)$ & $\mathrm{DC}$ & $\mathrm{C}$ & $\mathrm{NP}$ & $\mathrm{C}$ & NP & NP \\
\hline $1,770.9(5,810)$ & $\mathrm{DC}$ & $\mathrm{C}$ & $\mathrm{NP}$ & C & NP & NP \\
\hline $1,920.2(6,300)$ & $\mathrm{DC}$ & $\mathrm{C}$ & $\mathrm{NP}$ & $\mathrm{C}$ & $\mathrm{NP}$ & NP \\
\hline $2,042.2(6,700)$ & $\mathrm{DC}$ & $\mathrm{C}$ & $\mathrm{NP}$ & $\mathrm{C}$ & $\mathrm{NP}$ & $\mathrm{NP}$ \\
\hline
\end{tabular}

a Depth represents base of 3.0-m (10-ft) sample interval for drill cuttings.

b Sample type: $\mathrm{DC}=$ Drill cuttings

C Status of analyses at the time of this writing: $\mathbf{C}=$ analysis complete; $\mathbf{N P}=$ analysis not planned. Analysis type: $\mathbf{P T S}=$ polished thin section; $\mathbf{M P}=$ electron microprobe; $\mathbf{X R D}=\mathbf{x}$-ray diffraction; $\mathrm{XRF}=\mathrm{X}$-ray fluorescence; $\mathrm{Fe}^{2+} / \mathrm{Fe}^{3+}=$ wet chemical analysis for iron. 
Table 3-3

Well ER-12-2 Geophysical Log Summary

(Page 1 of 2)

\begin{tabular}{|c|c|c|c|c|c|c|}
\hline Geophysical Log Type ${ }^{a}$ & Log Purpose & $\begin{array}{l}\text { Logging } \\
\text { Service }\end{array}$ & $\begin{array}{l}\text { Date } \\
\text { Logged }\end{array}$ & Run Number & $\begin{array}{l}\text { Bottom of } \\
\text { Logged } \\
\text { Interval }^{\text {b }} \\
\text { meters (feet) }\end{array}$ & $\begin{array}{l}\text { Top of Logged } \\
\text { Interval b } \\
\text { meters (feet) }\end{array}$ \\
\hline * Natural Gamma Ray Spectroscopy & $\begin{array}{l}\text { Stratigraphic correlation, lithologic } \\
\text { determination, mineralogy, natural } \\
\text { and man-made radiation, fracture } \\
\text { identification }\end{array}$ & $\begin{array}{l}\text { Halliburton } \\
\text { Energy } \\
\text { Services }\end{array}$ & $\begin{array}{l}11 / 25 / 2002 \\
11 / 27 / 2002 \\
11 / 27 / 2002 \\
12 / 18 / 2002 \\
01 / 16 / 2003\end{array}$ & $\begin{array}{l}\text { SGR-1/GR-2 } \\
\text { SGR-2/GR-4 } \\
\text { SGR-3/GR-6 } \\
\text { SGR-4/GR-9 } \\
\text { SGR-5/GR-14 }\end{array}$ & $\begin{array}{c}393.8(1,292) \\
125.9(413) \\
175.3(575) \\
884.5(2,902) \\
2,084.2(6,838)\end{array}$ & $\begin{array}{c}3.0(10) \\
5.2(17) \\
6.1(20) \\
237.1(778) \\
891.5(2,925)\end{array}$ \\
\hline * Six Arm Caliper/Gamma Ray & $\begin{array}{l}\text { Borehole conditions, cement } \\
\text { volume calculation, fracture } \\
\text { identification }\end{array}$ & $\begin{array}{l}\text { Halliburton } \\
\text { Energy } \\
\text { Services }\end{array}$ & $\begin{array}{l}11 / 27 / 2002 \\
11 / 27 / 2002 \\
12 / 18 / 2002 \\
01 / 16 / 2003\end{array}$ & $\begin{array}{l}\text { CA6-1/ GR-4 } \\
\text { CA6-2/ GR-6 } \\
\text { CA6-3/ GR-8 } \\
\text { CA6-4/GR-13 }\end{array}$ & $\begin{array}{c}132.3(434) \\
182.3(598) \\
900.7(2,955) \\
2,094.0(6,870)\end{array}$ & $\begin{array}{c}5.2(17) \\
6.1(20) \\
234.7(770) \\
853.4(2,800)\end{array}$ \\
\hline${ }^{*}$ High Resolution Induction & $\begin{array}{l}\text { Lithologic determination, } \\
\text { stratigraphic correlation }\end{array}$ & $\begin{array}{l}\text { Halliburton } \\
\text { Energy } \\
\text { Services }\end{array}$ & $11 / 25 / 2002$ & HRI-1/GR-2 & $398.4(1,307)$ & $3.0(10)$ \\
\hline $\begin{array}{l}\text { * Dual Laterolog/Spontaneous } \\
\text { Potential }\end{array}$ & $\begin{array}{l}\text { Lithologic determination, } \\
\text { stratigraphic correlation, water } \\
\text { saturation }\end{array}$ & $\begin{array}{l}\text { Halliburton } \\
\text { Energy } \\
\text { Services }\end{array}$ & $\begin{array}{l}12 / 18 / 2002 \\
01 / 16 / 2003\end{array}$ & $\begin{array}{l}\text { DLL-1/SP-1/GR-9 } \\
\text { DLL-2/SP-2/GR-14 }\end{array}$ & $\begin{array}{c}899.2(2,950) \\
2,092.5(6,865)\end{array}$ & $\begin{array}{c}246.6(809) \\
891.5(2,925)\end{array}$ \\
\hline * Epithermal Neutron/Density & $\begin{array}{l}\text { Total water content, rock porosity, } \\
\text { stratigraphic correlation, lithologic } \\
\text { determination }\end{array}$ & $\begin{array}{l}\text { Halliburton } \\
\text { Energy } \\
\text { Services }\end{array}$ & $\begin{array}{l}12 / 19 / 2002 \\
01 / 17 / 2003\end{array}$ & $\begin{array}{l}\text { DSEN-1/SDL-1/GR-11 } \\
\text { DSEN-2/SDL-2/GR-15 }\end{array}$ & $\begin{array}{c}903.1(2,963) \\
2,096.4(6,878)\end{array}$ & $\begin{array}{c}237.7(780) \\
891.5(2,925)\end{array}$ \\
\hline Electric Micro Imager & $\begin{array}{l}\text { Lithologic characterization, } \\
\text { structural analysis, fracture and } \\
\text { void analysis. }\end{array}$ & $\begin{array}{l}\text { Halliburton } \\
\text { Energy } \\
\text { Services }\end{array}$ & $\begin{array}{l}11 / 27 / 2002 \\
11 / 27 / 2002 \\
12 / 18 / 2002 \\
01 / 16 / 2003\end{array}$ & $\begin{array}{l}\text { EMI-1/GR-4 } \\
\text { EMI-2/GR-6 } \\
\text { EMI-3/GR-8 } \\
\text { EMI-4/GR-13 }\end{array}$ & $\begin{array}{c}132.3(434) \\
182.3(598) \\
901.0(2,956) \\
2,097.0(6,880)\end{array}$ & $\begin{array}{c}59.4(195) \\
41.5(136) \\
253.9(833) \\
905.3(2,970)\end{array}$ \\
\hline Full Wave Sonic - Waveform & Fracture identification & $\begin{array}{l}\text { Halliburton } \\
\text { Energy } \\
\text { Services }\end{array}$ & $\begin{array}{l}12 / 19 / 2003 \\
01 / 17 / 2003\end{array}$ & $\begin{array}{l}\text { FWS-1/GR-10 } \\
\text { FWS-2/GR-16 }\end{array}$ & $\begin{array}{c}899.2(2,950) \\
2,093.7(6,869)\end{array}$ & $\begin{array}{c}237.7(780) \\
883.9(2,900)\end{array}$ \\
\hline * Full Wave Sonic - Delta-T & Porosity, seismic properties & $\begin{array}{l}\text { Halliburton } \\
\text { Energy } \\
\text { Services }\end{array}$ & $\begin{array}{l}12 / 19 / 2003 \\
01 / 17 / 2003\end{array}$ & $\begin{array}{l}\text { FWS-1/GR-10 } \\
\text { FWS-2/GR-16 }\end{array}$ & $\begin{array}{c}899.2(2,950) \\
2,093.7(6,869)\end{array}$ & $\begin{array}{c}232.3(762) \\
883.9(2,900)\end{array}$ \\
\hline
\end{tabular}


Table 3-3

Well ER-12-2 Geophysical Log Summary

(Page 2 of 2)

\begin{tabular}{|c|c|c|c|c|c|c|}
\hline Geophysical Log Type a & Log Purpose & $\begin{array}{l}\text { Logging } \\
\text { Service }\end{array}$ & $\begin{array}{l}\text { Date } \\
\text { Logged }\end{array}$ & Run Number & $\begin{array}{l}\text { Bottom of } \\
\text { Logged } \\
\text { Interval }^{\mathbf{b}} \\
\text { meters (feet) }\end{array}$ & $\begin{array}{l}\text { Top of Logged } \\
\text { Interval } \\
\text { meters (feet) }\end{array}$ \\
\hline Temperature & $\begin{array}{l}\text { Groundwater temperature, fracture } \\
\text { identification }\end{array}$ & $\begin{array}{l}\text { Halliburton } \\
\text { Energy } \\
\text { Services }\end{array}$ & $\begin{array}{l}11 / 25 / 2002 \\
11 / 27 / 2002 \\
11 / 27 / 2002 \\
12 / 18 / 2002 \\
01 / 16 / 2003\end{array}$ & $\begin{array}{c}\text { TL-1/GR-1 } \\
\text { TL-2/GR-3 } \\
\text { TL-3/GR-5 } \\
\text { TL-4/GR-7 } \\
\text { TL-5/GR-12 }\end{array}$ & $\begin{array}{c}382.5(1,255) \\
125.0(410) \\
168.9(554) \\
888.2(2,914) \\
2,085.1(6,841)\end{array}$ & $\begin{array}{c}\text { Surface } \\
\text { Surface } \\
\text { Surface } \\
121.9(400) \\
426.7(1,400)\end{array}$ \\
\hline $\begin{array}{l}\text { Percussion Gun Sidewall Coring } \\
\text { Tool }\end{array}$ & Geologic samples & $\begin{array}{l}\text { Halliburton } \\
\text { Energy } \\
\text { Services }\end{array}$ & $\begin{array}{l}12 / 19 / 2002 \\
01 / 18 / 2003\end{array}$ & $\begin{array}{l}\text { SWC-1 } \\
\text { SWC-2 }\end{array}$ & $\begin{array}{c}894.9(2,936) \\
1,215.5(3,988)\end{array}$ & $\begin{array}{l}696.5(2,285) \\
919.9(3,018)\end{array}$ \\
\hline Rotary Sidewall Coring Tool & Geologic samples & $\begin{array}{l}\text { Halliburton } \\
\text { Energy } \\
\text { Services }\end{array}$ & $01 / 19 / 2003$ & RSWC-1 & $2,090.9(6,860)$ & $960.1(3,150)$ \\
\hline${ }^{*}$ Chemistry/Temperature Log & $\begin{array}{l}\text { Groundwater chemistry and } \\
\text { temperature, formation } \\
\text { transmissivity }\end{array}$ & $\begin{array}{l}\text { Desert } \\
\text { Research } \\
\text { Institute }\end{array}$ & $01 / 19 / 2003$ & Chem-1/TL-6 & $2,097.9(6,883)$ & $899.2(2,950)$ \\
\hline * Thermal Flow Meter & Groundwater flow rate & $\begin{array}{l}\text { Desert } \\
\text { Research } \\
\text { Institute }\end{array}$ & $01 / 19 / 2003$ & TFM-1 & $1,768.8(5,800)$ & $883.9(2,900)$ \\
\hline North Seeker Earth-Rate Gyro & $\begin{array}{l}\text { Bottom hole location, true vertical } \\
\text { depth }\end{array}$ & $\begin{array}{l}\text { Baker } \\
\text { Hughes } \\
\text { Inteq }\end{array}$ & $04 / 15 / 2003$ & DRG-1 & $2,092.5(6,865)$ & Surface \\
\hline
\end{tabular}

a Logs presented in geophysical log summary, Appendix D, are indicated by *.

b Drilled depth below ground surface. 


\subsection{Geology and Hydrogeology}

\subsection{Introduction}

This section describes the geology and hydrogeology of Well ER-12-2. The basis for the discussions in Section 4.0 is the detailed lithologic log presented in Appendix C. The detailed lithologic log was developed using drill cuttings and sidewall core samples, geophysical logs, and drilling parameters. Results from petrographic, mineralogic, and chemical analyses provided by Giday WoldeGabriel of LANL for select lithologic samples (WoldeGabriel, 2003) were incorporated into the lithologic log.

\subsection{Geology}

This section is subdivided into three discussions relating to the geology of Well ER-12-2. Section 4.2.1 describes the geologic setting of Yucca Flat and Well ER-12-2. The stratigraphic and lithologic units penetrated at the well are discussed in Section 4.2.2. Because of the significant influence some alteration products have on the hydraulic properties of certain rocks, alteration of the rocks encountered at the well is discussed separately in Section 4.2.3. More detailed descriptions of the stratigraphy, lithology, and alteration of the rocks encountered are provided in the detailed lithologic log presented in Appendix C.

\subsubsection{Geologic Setting}

Well ER-12-2 lies on a southeast-sloping surface of young alluvium in the northwestern portion of Yucca Flat (Figures 4-1 and 4-2). Yucca Flat is a hydrologically closed, Cenozoic-age basin formed as a result of basin-and-range extension.

Rocks exposed in the highlands around the margins of Yucca Flat consist mostly of Tertiary volcanic rocks that overlie complexly folded and faulted Paleozoic sedimentary rocks (Slate et al., 1999). Mesozoic granitic rocks are exposed locally at the north end of the basin. The volcanic rocks exposed in the highlands around Yucca Flat are mostly Miocene tuffs of generally rhyolitic composition erupted from large calderas located west and northwest of Yucca Flat. Paleozoic sedimentary rocks include Late Proterozoic and Lower Cambrian siliciclastic rocks, Middle Cambrian to Devonian carbonate rocks, Mississippian siliciclastic rocks, and Pennsylvanian and Lower Permian carbonate rocks. Extensive drilling in Yucca Flat has confirmed that the rock units exposed along the margins of the basin are present beneath Yucca Flat, buried under thick aprons of Quaternary and Tertiary alluvial debris shed from the exposed highlands during basin development. 
This page intentionally left blank. 


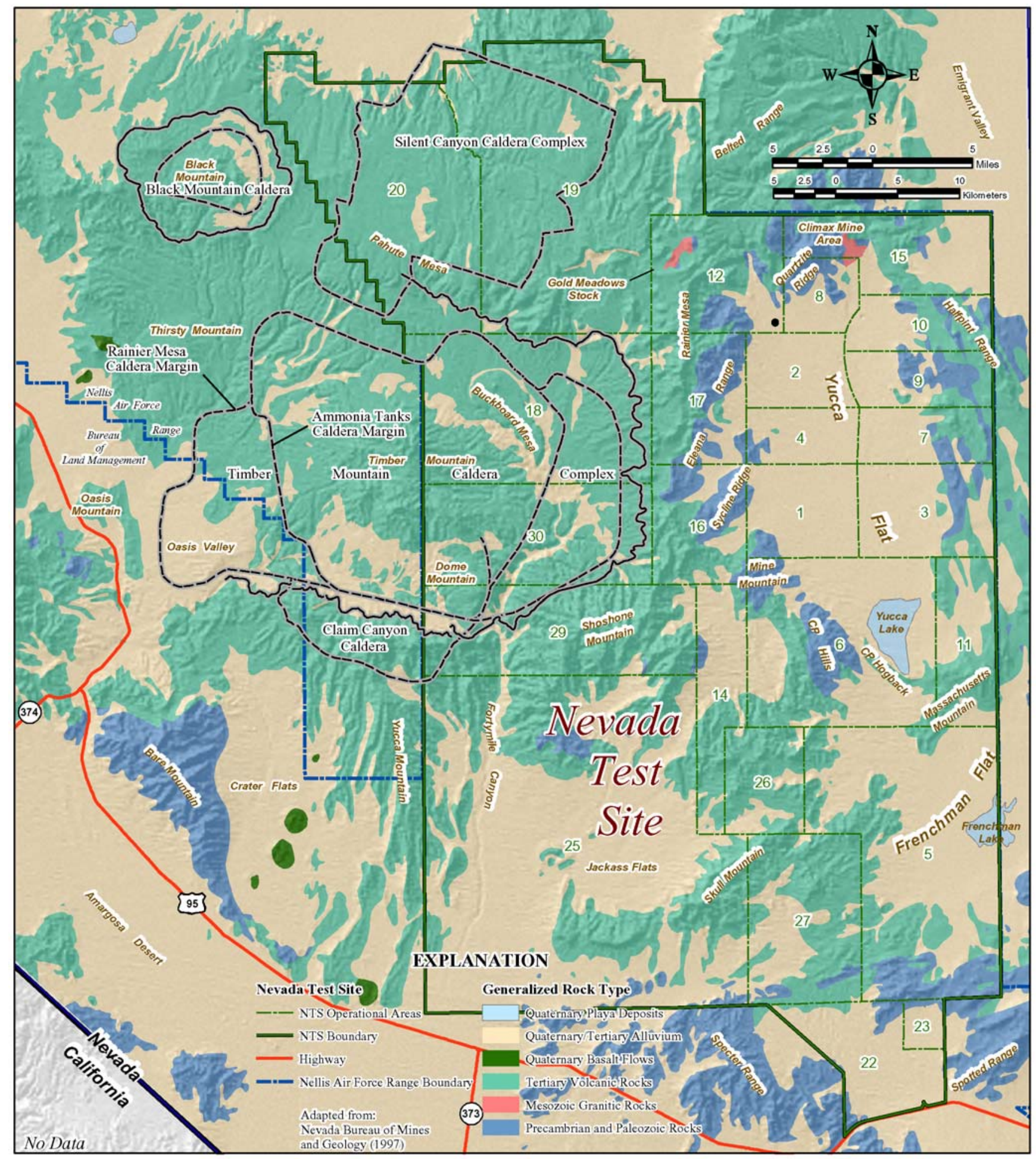

Figure 4-1

Generalized Surface Geologic Map of the Nevada Test Site Area Showing Location of Well ER-12-2 
This page intentionally left blank. 


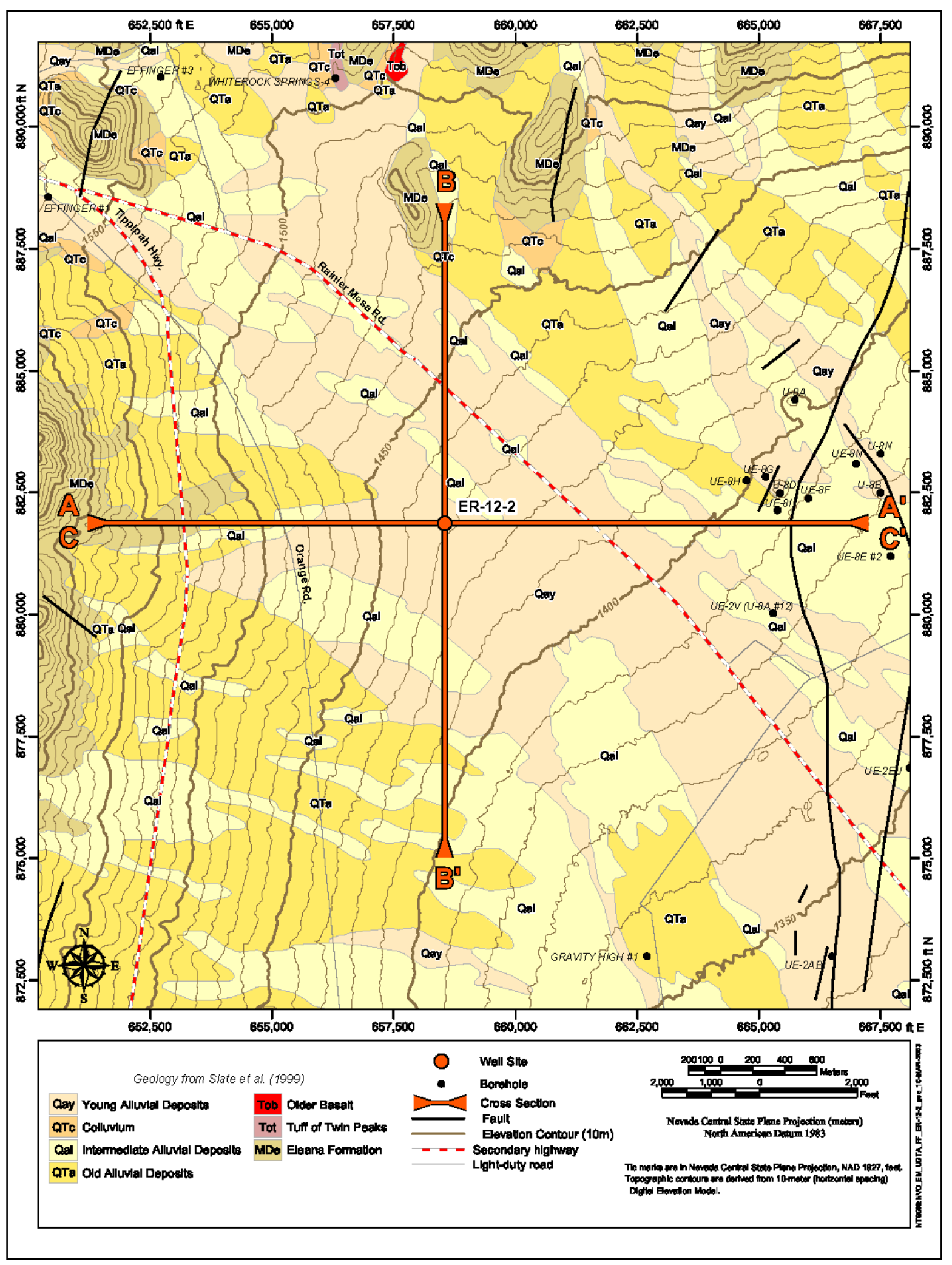

Figure 4-2

Surface Geologic Map of the Well ER-12-2 Site 
This page intentionally left blank. 
Rocks in the Yucca Flat area are cut by numerous, generally north-striking normal faults associated with basin-and-range extension. These extensional structures overprint older contractional structures that include folds and thrust faults.

Contractional structural events are particularly significant with regards to the geology encountered at Well ER-12-2. During the Late Devonian and Early Mississippian periods (360 to 325 million years ago [Ma]), a mountain-building event called the Antler orogeny occurred north and west of the NTS (Cashman and Trexler, 1991; Trexler et al., 1996; and Cole and Cashman, 1999). East of the developing Antler highlands, a foreland basin formed in the vicinity of the NTS. During the Late Devonian and most of the Mississippian periods (360 to $310 \mathrm{Ma}$ ), coarse clastic debris was shed off the highlands and deposited by turbidity currents in the trough of the basin, forming submarine fan deposits. These marine siliciclastic deposits are represented in the Yucca Flat area by the Eleana Formation. To the east, finer-grained mudrocks were deposited in an adjacent restricted marginal shelf environment and are represented in the Yucca Flat area by the Chainman Shale. At some time between 250 and $100 \mathrm{Ma}$ (Late Permian through Early Cretaceous), east-directed thrust faulting associated with the Belted Range thrust system pushed the coarser-grained western facies deposits (i.e., Eleana Formation) eastward and over the eastern facies deposits (i.e., Chainman Shale) in the vicinity of Well ER-12-2 (Cole and Cashman, 1999).

\subsubsection{Stratigraphy and Lithology}

The stratigraphic and lithologic units penetrated at Well ER-12-2 are illustrated in Figure 4-3, and an interpretation of the possible distribution of stratigraphic units in the vicinity of Well ER-12-2 is shown in cross section in Figures 4-4 and 4-5. Ongoing and planned geologic studies, including petrography, biostratigraphy, borehole image analysis, and magnetotelluric surveys, will likely provide important data to better constrain interpretations of this area.

Drilling at Well ER-12-2 began in young alluvium and penetrated $137.2 \mathrm{~m}$ (450 ft) of Quaternary and Tertiary alluvium. Although the alluvial matrix has a tuffaceous character due to the presence of biotite, small pumice fragments, and felsic minerals (constituents common in the local volcanic units), the predominant clasts are sandstone, quartzite, and conglomerate typical of the Eleana Formation that is exposed in the highlands north and west of the well.

The alluvial deposits overlie $48.8 \mathrm{~m}$ (160 ft) of tuffaceous volcanic rocks consisting of bedded tuff and nonwelded to densely welded ash-flow tuff. The volcanic rocks generally consist of moderate amounts of felsic phenocrysts, including subordinate quartz and substantial amounts of mafic minerals including 
biotite and subordinate hornblende. This mineralologic assemblage, combined with the stratigraphic position of this relatively thin interval of volcanic rocks directly overlying Paleozoic sedimentary rocks, suggests that the volcanic rocks likely include early eruptive units of the southwestern Nevada volcanic field such as the 15.25-million-year-old (Sawyer et al., 1994) Redrock Valley Tuff. Beginning at $185.9 \mathrm{~m}$ (610 ft), Well ER-12-2 penetrated $289.6 \mathrm{~m}$ (950 ft) of mostly grayish black to black, fissile, and sparsely pyritic shale assigned to the Mississippian Chainman Shale. (In this report the term shale also includes siltstone.) The assignment of this interval to the Chainman Shale is based on the lithology of the interval, including the presence of smectite and swelling clays, and stratigraphic and structural relationships in the area (Cashman and Trexler, 1991; Trexler et al., 1996; Cole et al., 1997; and Cole and Cashman, 1999). Near-surface weathering has resulted in the formation of iron oxides that impart a brownish color to the upper $30.5 \mathrm{~m}$ (100 ft) of the interval. Mineralogical analyses of select drill cuttings samples from the Chainman Shale in ER-12-2 indicate that considerable amounts of smectite are present (WoldeGabriel et al., 2003). This is consistent with observations that swelling clays are common within the Chainman Shale in drill hole UE-17e located approximately 10 kilometers (6.2 miles) south-southwest of Well ER-12-2 (Trexler et al., 1996). Tight hole conditions, which are commonly caused by swelling clays, were a persistent problem while drilling through the Chainman Shale at Well ER-12-2 (see Sections 2.2 and 2.3).

Below the Chainman Shale, the well penetrated 1,622.5 m (5,323 ft) of grayish-black to black shale, argillite, sandstone, quartzite, and limestone assigned to the Mississippian and upper Devonian Eleana Formation. Pyrite is rather sparse but ubiquitous. The shale typically is more indurated and less fissile than the rocks of the Chainman Shale, and considerably more electrically resistive (approximately 10 times higher; see Dual Laterolog in Appendix D). The argillite is very well indurated and typically occurs as blocky nonfissile fragments in the drill cuttings samples. (The term argillite is used in this report for very well indurated nonfissile mudrocks.) Mineralogical analyses of select shale and argillite drill cuttings samples show that, unlike the overlying Chainman Shale, illite is the dominant clay mineral and smectite appears to be only a very minor constituent (WoldeGabriel et al., 2003). This is consistent with the absence of tight spots caused by swelling clays during drilling with air-foam below approximately $903.4 \mathrm{~m}$ (2,954 ft). Thick, monotonous sections of shale and argillite were logged from 576.1 to $771.1 \mathrm{~m}(1,890$ to $2,530 \mathrm{ft})$ and from $1,069.2$ to $1,674.3 \mathrm{~m}(3,508$ to $5,493 \mathrm{ft})$ in Well ER-12-2.

Sandstone and quartzite in this interval are generally well to very well indurated and fine-grained. (In this report the term quartzite is used for very well indurated, silica-cemented siliciclastic rocks composed 


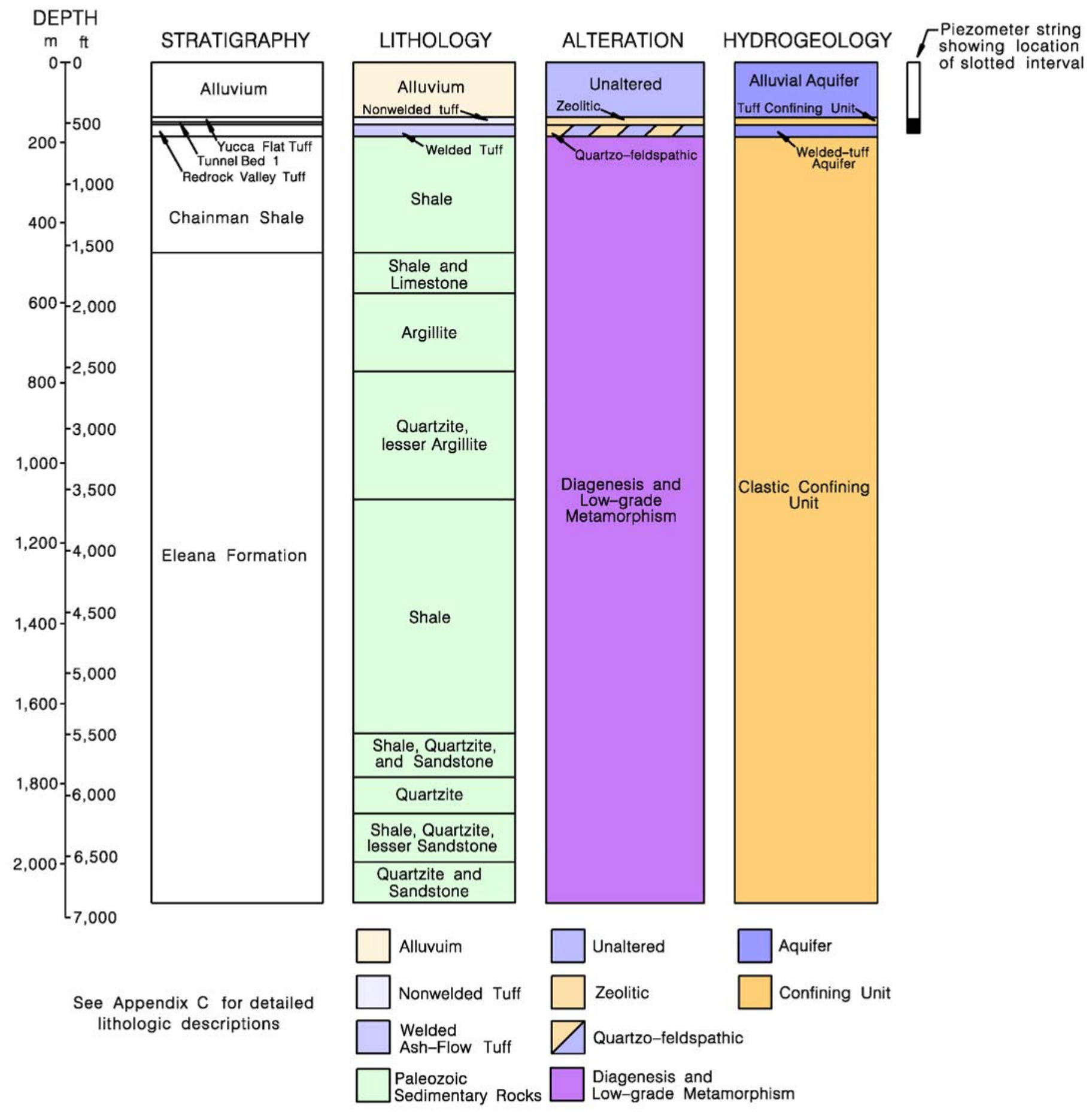

Figure 4-3

Geology and Hydrogeology at Well ER-12-2 
This page intentionally left blank. 


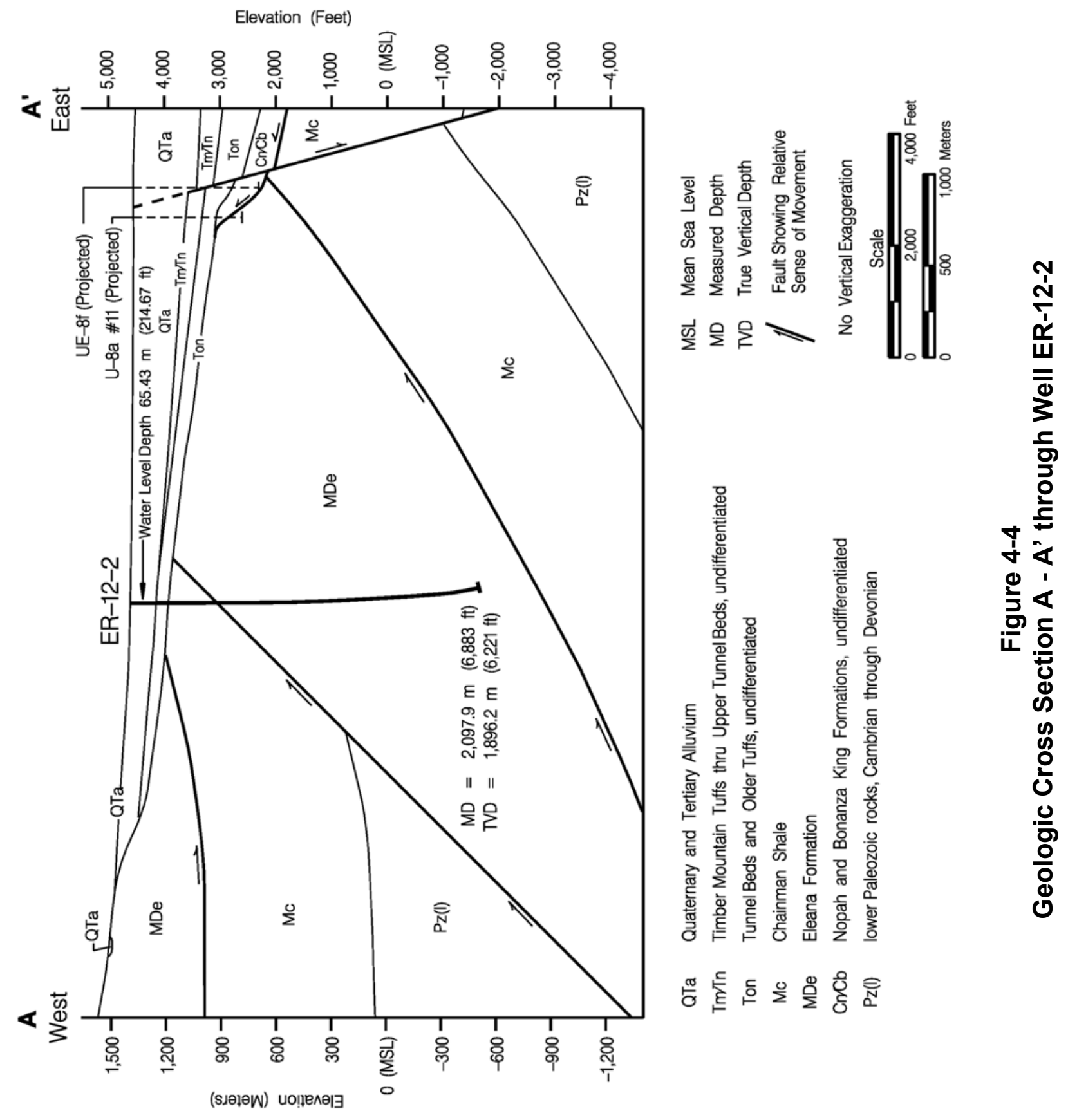




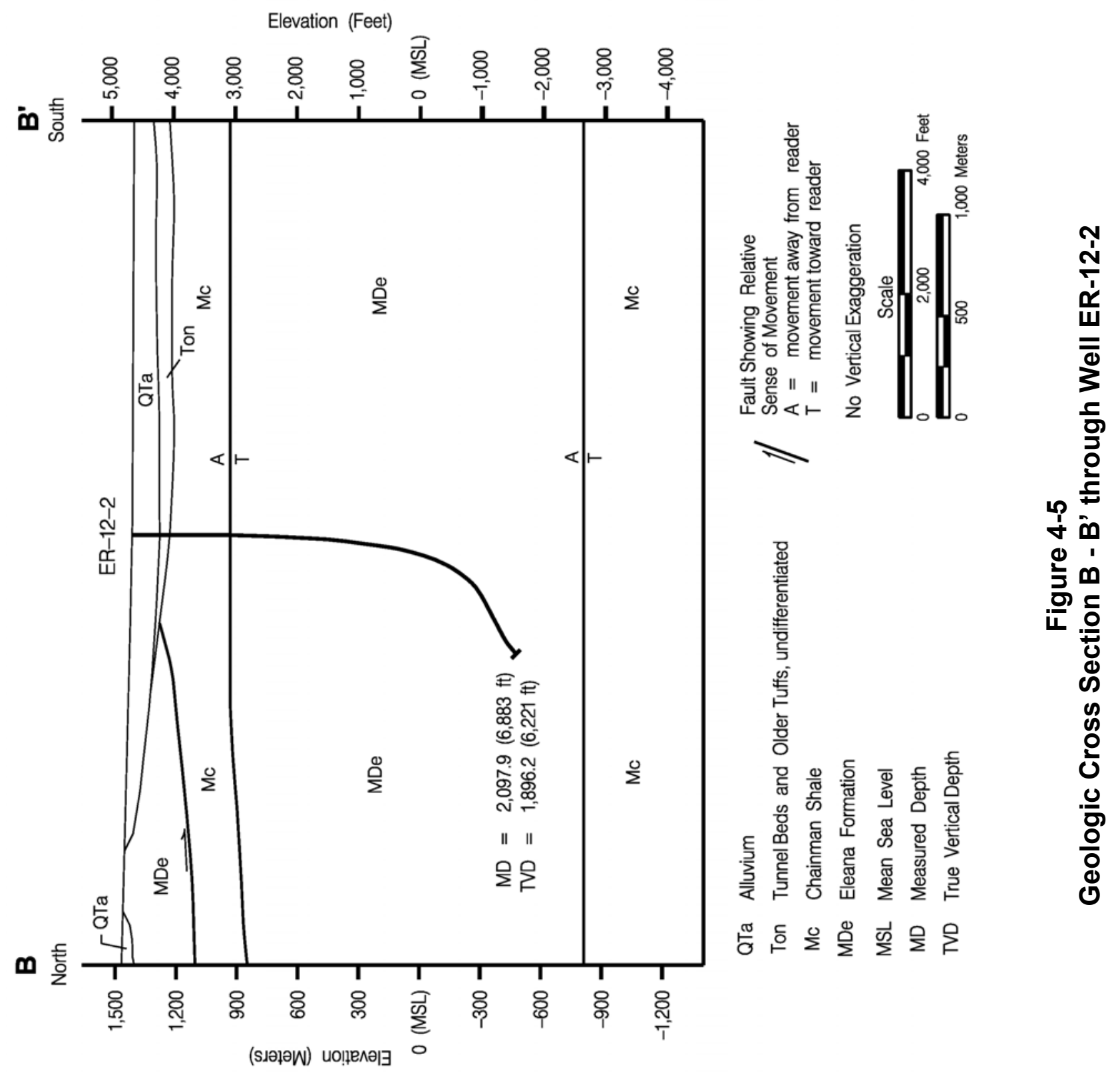


of sand-size constituents that break across constituent grains.) Coarser grained beds including chert conglomerate are also present. Constituents of these siliciclastic rocks are predominately quartz grains and chert fragments, with many fewer feldspar grains and shale fragments. Thus, the sandstone and quartzite in Well ER-12-2 can be classified as chert litharenites (Cashman and Trexler, 1991). Silica is the cementing agent in the quartzite beds, whereas carbonate cement appears to be present along with silica cement in the sandstone. Mineralogical analyses indicate that the sandstone and quartzite are composed of approximately 75 percent quartz (WoldeGabriel et al., 2003). Sandstone and quartzite beds generally less than $3 \mathrm{~m}$ (10 ft) thick are interbedded with shale and argillite in several intervals below $771.1 \mathrm{~m}(2,530 \mathrm{ft})$, though more massive deposits of sandstone and quartzite up to $91.4 \mathrm{~m}$ $(300 \mathrm{ft})$ thick were also logged in this section of the borehole.

Bioclastic limestone is interbedded with shale at the top of the Eleana Formation in Well ER-12-2, from 475.5 to $576.1 \mathrm{~m}$ (1,560 to $1,890 \mathrm{ft}$ ). The limestone consists mostly of coarse-grained recrystallized limestone clasts including fossil fragments, and rare fine- to medium-grained, rounded quartz grains and subrounded chert fragments. The cement appears to be a combination of sparry calcite, silica, and argillaceous material. Overall, this interval of limestone and shale consists of approximately 60 percent shale and 40 percent limestone, however the bottom $24.4 \mathrm{~m}$ (80 ft) of the interval is approximately 90 percent limestone and 10 percent thin shale beds.

The assignment of the rocks below $475.5 \mathrm{~m}(1,560 \mathrm{ft})$ in Well ER-12-2 to the Eleana Formation is based on the occurrence of bioclastic limestone in the upper part of the section and chert litharenites throughout the section. The Eleana Formation in the Eleana Range west of Well ER-12-2 includes bioclastic limestone in the upper part and chert litharenite beds generally throughout the formation (Poole et al., 1961; Gibbons et al., 1963; and Trexler et al., 1996). The occurrence of chert litharenites is particularly diagnostic for distinguishing the Eleana Formation from the Chainman Shale. Sandstone and quartzite described in the Chainman Shale are quartz arenites and have a different source than the chert litharenites in the Eleana Formation (Cashman and Trexler, 1991).

Geophysical logs and drilling rate charts from Well ER-12-2 show an abrupt contact between the Eleana Formation and the Chainman Shale. The spectral gamma ray log indicates possible fracturing associated with the contact. These data are consistent with a structural (fault) contact between the Chainman Shale and Eleana Formation in the well. 


\subsubsection{Alteration}

Due to the poorly consolidated nature of the alluvium that resulted in the separation and loss of fines during the drilling process, very little alluvial matrix was preserved in the drill cuttings samples, and thus was unavailable for analysis of alteration minerals. However, it is unlikely that the relatively thin and shallow interval of alluvium at Well ER-12-2 has been significantly altered since deposition.

The presence of silicification and of altered feldspar phenocrysts and mafic minerals suggests that much of the volcanic section has undergone quartzo-feldspathic alteration. The presence of quartzofeldspathic alteration in the volcanic rocks at Well ER-12-2 may indicate that these units were probably once buried by rather thick deposits of younger tuffs that were subsequently eroded off during the initial development of Yucca Flat. In deeper portions of Yucca Flat southwest of Well ER-12-2, where the volcanic section is much thicker, the older volcanic rocks near the base of the Tertiary section typically exhibit quartzo-feldspathic alteration.

In addition to typical diagenetic effects in clastic rocks such as compaction and cementation, many of the rocks in the Eleana Formation appear to have undergone low-grade metamorphism that has resulted in the formation of argillite and quartzite.

\subsection{Predicted and Actual Geology}

The geology encountered at Well ER-12-2 was significantly different than predicted prior to drilling

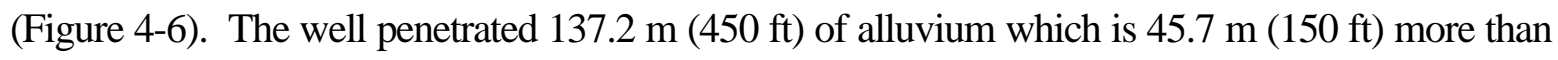
predicted. It was also predicted that approximately $61.0 \mathrm{~m}$ ( $200 \mathrm{ft})$ of upper volcanic units such as units of the Timber Mountain Group would be encountered below the alluvial deposits. However, these units were not present and older volcanic units such as Redrock Valley Tuff directly underlie the alluvial deposits. The older volcanic rocks were expected to be approximately $61.0 \mathrm{~m}$ (200 ft) thick, and $48.8 \mathrm{~m}(160 \mathrm{ft})$ were actually penetrated.

Below the volcanic rocks Well ER-12-2 was predicted to encountered a thin $(61.0 \mathrm{~m}$ [200 ft]) sliver of Eleana Formation that forms the leading edge of an east-vergent foreland imbricate thrust sheet placing Eleana Formation over Chainman Shale. However, Chainman Shale was encountered directly below the volcanic rocks, indicating that the leading edge of the imbricate thrust is west of Well ER-12-2, between the well and exposures of Eleana Formation in the Eleana Range. 

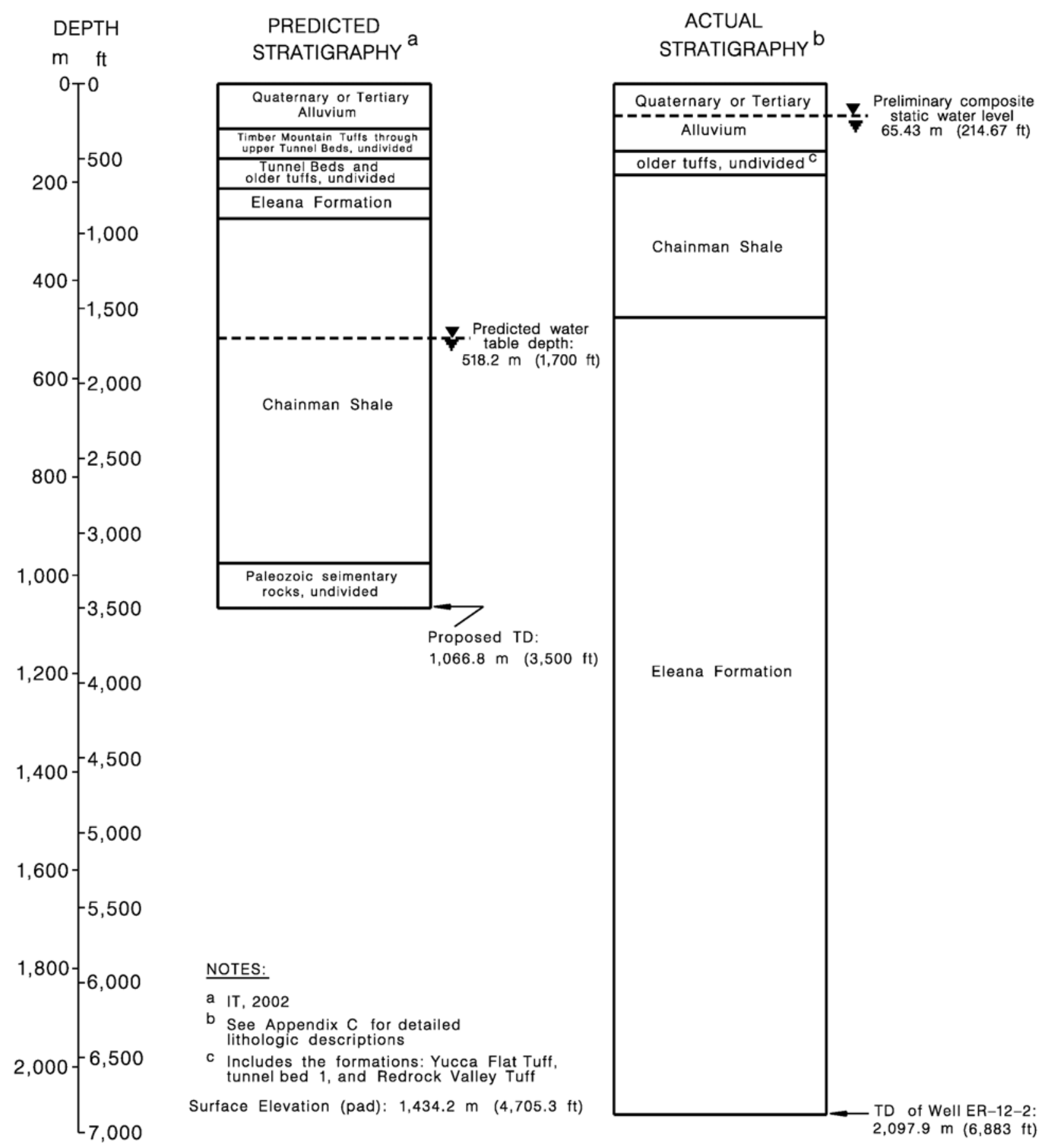

Eleana Formation

TD of Well ER-12-2:

$2,097.9 \mathrm{~m}(6,883 \mathrm{ft})$

Figure 4-6

Predicted and Actual Stratigraphy at Well ER-12-2 
It was predicted that $701 \mathrm{~m}(2,300 \mathrm{ft})$ of Chainman Shale would be penetrated before encountering Paleozoic carbonate rocks were encountered. However, after penetrating $289.6 \mathrm{~m}(950 \mathrm{ft})$ of Chainman Shale the well encountered the Eleana Formation at the depth of $475.5 \mathrm{~m}(1,560 \mathrm{ft})$. The well eventually penetrated 1,622.5 m (5,323 ft) of Eleana Formation, and reached TD within the

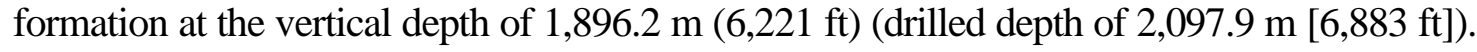

\subsection{Hydrogeology}

The alluvium, although unsaturated, is classified hydrogeologically as an alluvial aquifer based on its lithologic character. The interval of zeolitic nonwelded and bedded tuffs encountered from 137.2 to $156.1 \mathrm{~m}$ (450 to $512 \mathrm{ft}$ ) is classified as tuff confining unit because zeolitic alteration of poorly welded tuffs severely reduces the ability of these volcanic rocks to transmit groundwater. The welded tuff encountered from 156.1 to $185.9 \mathrm{~m}$ (512 to $610 \mathrm{ft})$ is classified as welded-tuff aquifer due to the tendency of these brittle rocks to fracture. Water was first encountered during drilling at $166.4 \mathrm{~m}$ (546 ft) within the welded tuff, where it appears to be perched. The rocks assigned to the Chainman Shale and Eleana Formation are classified as clastic confining unit, based on the fine-grained siliciclastic nature of these rocks.

To develop hydrostratigraphic framework models for this area, various blocks of Paleozoic sedimentary rocks have been defined as HSUs on the basis of their hydrogeologic character and their extent and thickness. The LCA3 consists of allochthonous (i.e., thrust-faulted), Middle Devonian through Middle Cambrian carbonate rocks in the upper plates of Mesozoic thrust faults such as the Belted Range and CP faults. The UCCU consists of Mississippian and Upper Devonian siliciclastic rocks that are represented in the Yucca Flat vicinity by the Chainman Shale and Eleana Formation. The LCA consists of autochthonous (i.e., not thrust-faulted) Middle Devonian through Middle Cambrian carbonate rocks. Neither LCA nor LCA3 carbonate rocks were encountered at this site. See Gonzales et al. (1998) and Gonzales and Drellack (1999) for additional explanations of the geology and hydrogeology of Yucca Flat and the Well ER-12-2 area. An interpretation of the possible distribution of hydrogeologic units at Well ER-12-2 is shown in cross section on Figure 4-7. 


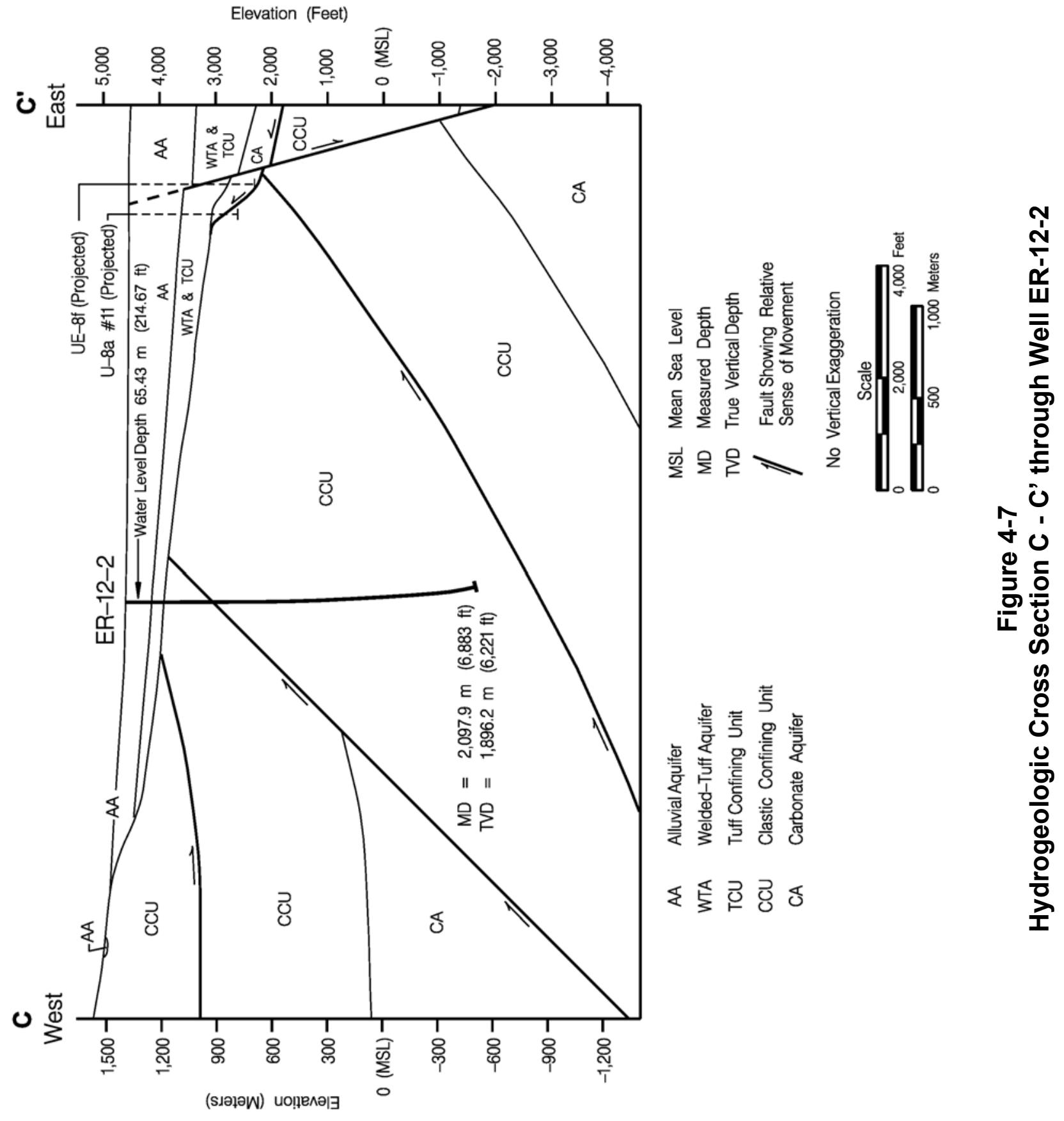


This page intentionally left blank. 


\subsection{Hydrology}

\subsection{Preliminary Water-Level Information}

Prior to drilling, the water level within the UCCU at Well ER-12-2 was estimated to be $518.2 \mathrm{~m}$ $(1,700 \mathrm{ft})$ below ground surface. However, measurements made after TD was reached indicate that the potentiometric surface associated with the UCCU is much different than predicted. The water level in the well on January 16, 2003, one day after TD of the well was reached, was at $446.2 \mathrm{~m}(1,464 \mathrm{ft})$ based on readings of the HES temperature log. Approximately 3 days later the level was $207.0 \mathrm{~m}$ (679 ft) based on indications from Desert Research Institute's (DRI) chemistry log. The water level continued to rise, and was measured at $65.43 \mathrm{~m}$ (214.67 ft) on March 3, 2003, by Shaw using a wireline probe. The water level inside the piezometer string isolated within welded volcanic rocks was measured at $127.14 \mathrm{~m}$ (417.13 ft) by Shaw on March 3, 2003 (Shaw, 2003).

\subsection{Water Production}

Water production was estimated during drilling of Well ER-12-2 on the basis of LiBr dilution data as measured by Shaw field personnel (Shaw, 2003). The water production rate while drilling Well ER-12-2 remained relatively low, reflecting the predominance of confining units encountered in the well. Measurable water production of approximately 57 liters per minute (lpm) (15 gallons per minute [gpm]) was first noted at the depth of about $166.4 \mathrm{~m}$ (546 ft) within welded tuff. This perched water zone was cased off as the borehole was advanced. During drilling in the Chainman Shale, water production was generally less than $38 \mathrm{lpm}(10 \mathrm{gpm})$. Water production increased within the Eleana Formation, but still remained relatively low at 189 to 379 lpm (50 to 100 gpm). Estimated water production rates during drilling are presented graphically in Appendix A-1.

\subsection{Preliminary Flow Meter Data}

Flow meter data, along with temperature, electrical conductivity (EC), and $\mathrm{pH}$ measurements, can be used to characterize borehole fluid variability, which may indicate inflow and outflow zones. DRI personnel made measurements with their thermal flow meter at 7 locations within the Eleana Formation between the depths 883.9 and 1,767.8 $\mathrm{m}$ (2,900 and 5,800 ft) shortly after drilling was completed. The thermal flow meter data indicate upward flow at the 2 highest measurement locations, at 883.9 and $922.0 \mathrm{~m}(2,900$ and 3,025 ft), and downward flow at the 5 measurement locations between 1,028.4 and $1,767.8 \mathrm{~m}(3,374$ and 5,800 ft). 
In addition, DRI ran a chemistry log, which included measurements of temperature and EC from 899.2 to $2,097.9 \mathrm{~m}$ (2,950 to $6,883 \mathrm{ft})$. The $\mathrm{pH}$ tool was not run because the depth of the well exceeded the maximum working depth of the tool. Temperature in the well increased gradually from 39.03 degrees

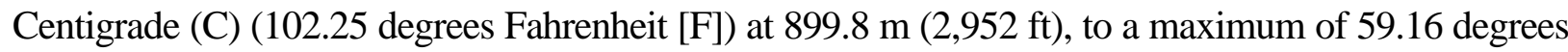
$\mathrm{C}(138.49$ degrees $\mathrm{F})$ at 2,097.9 $\mathrm{m}(6,883 \mathrm{ft})$. The EC values also increased gradually with depth, but show no abrupt changes within the logged portion of the well.

\subsection{Preliminary Groundwater Characterization Samples}

Following geophysical logging on January 19, 2003, DRI and Shaw collected preliminary groundwater characterization samples within the open borehole. Two 6-liter samples were collected at the depths of

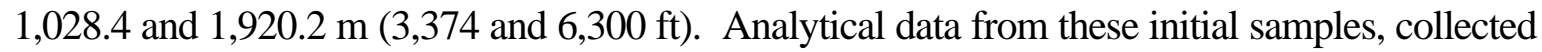
before formal well development, will provide a basis for comparison with future groundwater chemistry data. 


\subsection{Precompletion and Open-Hole Development}

The only precompletion development conducted in Well ER-12-2 consisted of circulating fluid for 30 minutes to clean the borehole prior to the final logging operation. 
This page intentionally left blank. 


\subsection{Well Completion}

\subsection{Introduction}

Well completion refers to the installation in a borehole of a string of tubing or casing that is slotted or screened at one or more locations along its length. The completion process also typically includes emplacement of backfill materials around the casing, with coarse fill such as gravel adjacent to the open intervals and impervious materials such as cement placed between or above the open intervals to isolate them. The tubing or casing serves as a conduit for insertion of a pump in the well, for inserting devices for measuring fluid level, and for sampling, so that accurate potentiometric and water chemistry data can be collected from known portions of the borehole.

The proposed well completion design for Well ER-12-2 as presented in the Yucca Flat Drilling Criteria (IT, 2002) is described in Subsection 7.2.1, and the actual well completion design, based on the hydrogeology encountered in the borehole, is presented in Subsection 7.2.3. The completion method is presented in Section 7.3. No production casing was installed in the well, but a piezometer was installed in the upper part of the borehole. Figure 7-1 is a schematic diagram of the final well-completion design for the well, and Figure 7-2 shows a plan view and profile of the wellhead surface completion.

Table $7-1$ is a construction summary for the piezometer.

\subsection{Well Completion Design}

The final completion design differs considerably from the proposed design, as described in the following sections.

\subsubsection{Proposed Completion Design}

The original completion design (presented in IT, 2002) was based on the assumption that Well ER-12-2 would penetrate through the UCCU and reach TD within the LCA. The well was planned to be completed with a single casing string of 51/2-in. stainless steel casing suspended from 7e -in. carbon-steel casing and extending into the LCA. The bottom portion of the 51/2-in. casing within the LCA would be slotted, gravel-packed, and isolated from the overlying UCCU with cement. A $2 f$-in. stainless-steel piezometer tube would be positioned outside the completion string, at a depth just above the top of the LCA. The bottom of the tubing would be slotted and gravel packed, and would be isolated with cement. Another $2 f$-in. stainless-steel piezometer tube was to be 


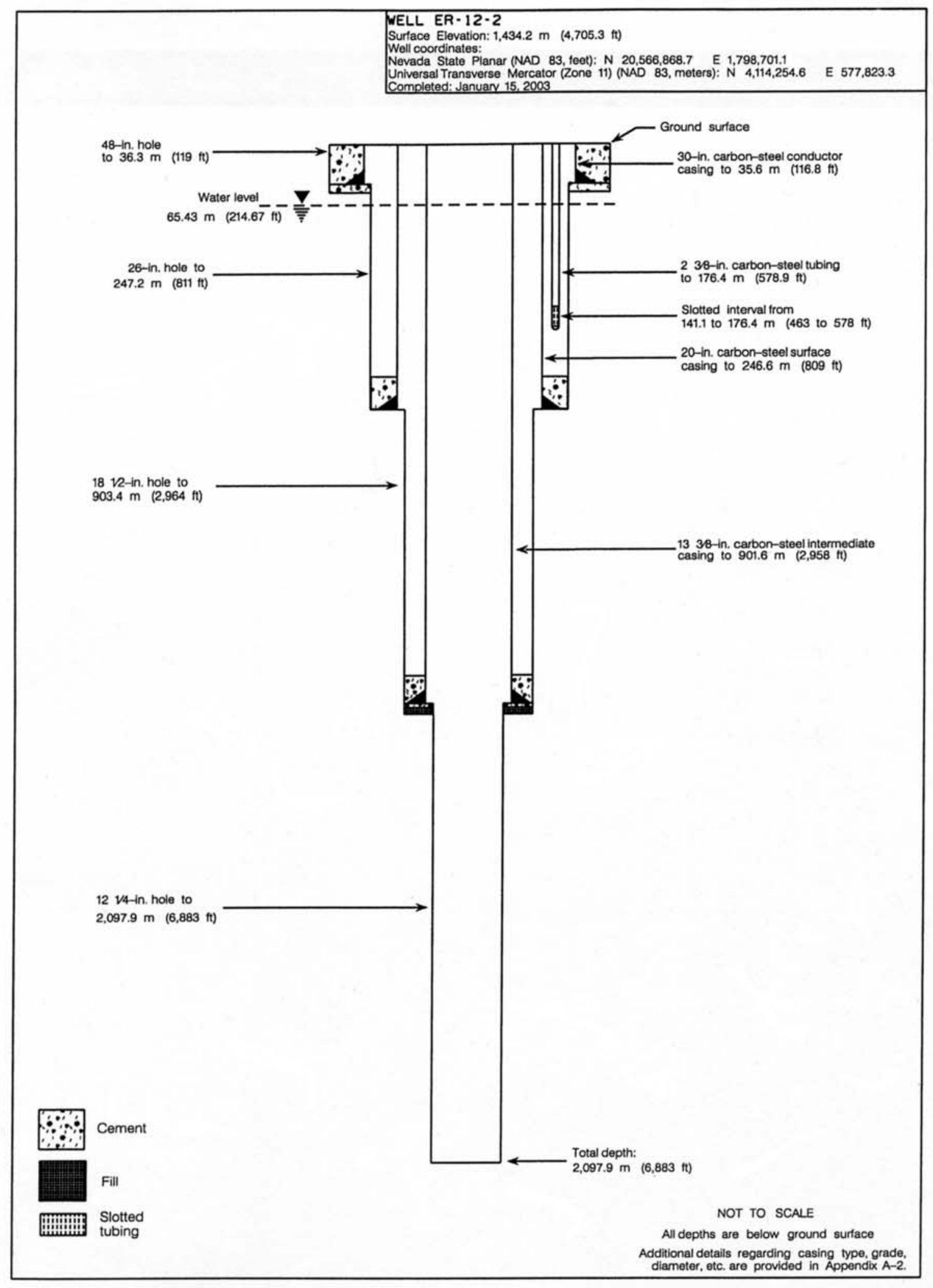

Figure 7-1

As-Built Completion Schematic for Well ER-12-2 


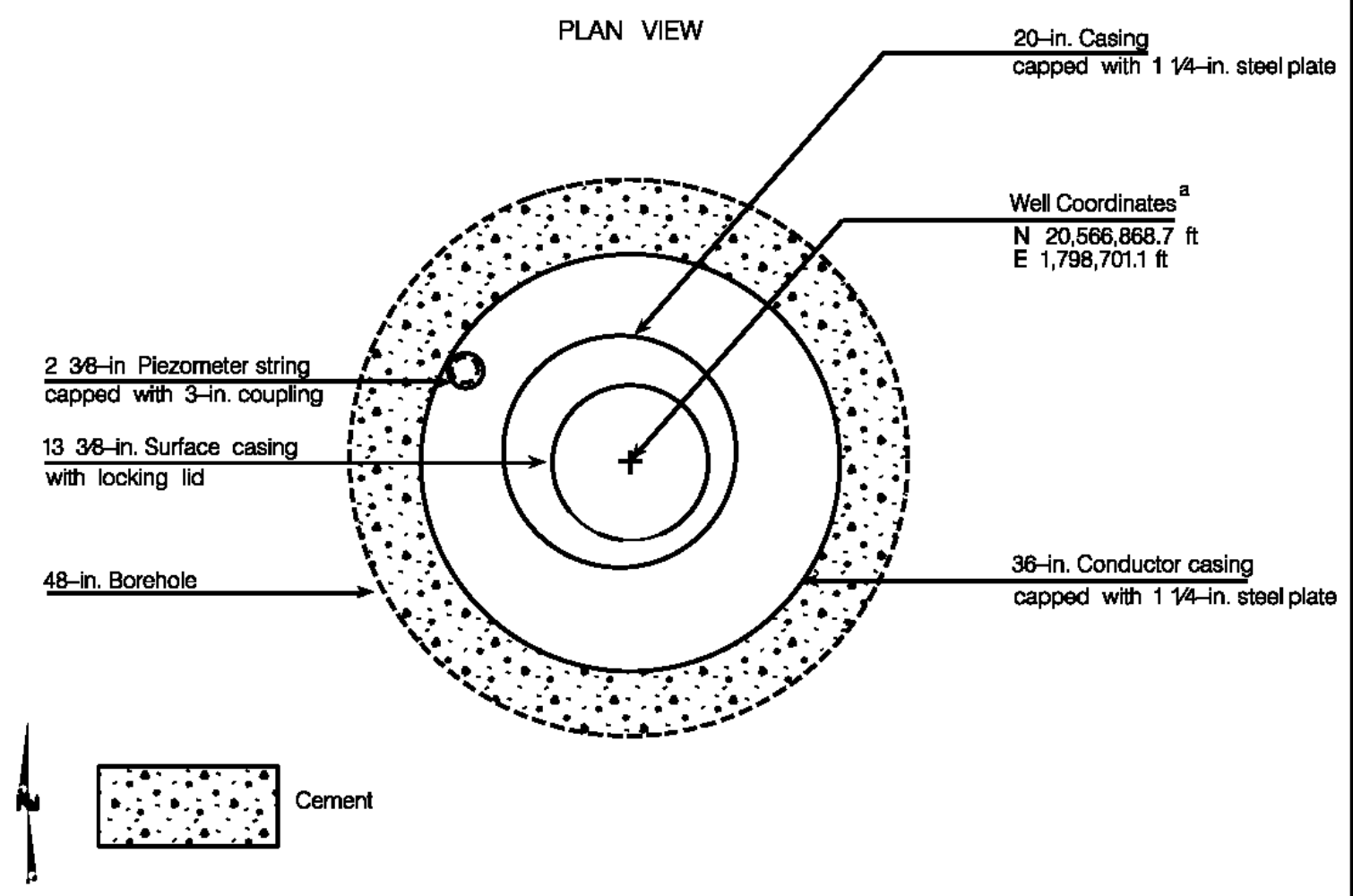

PROFILE VIEW

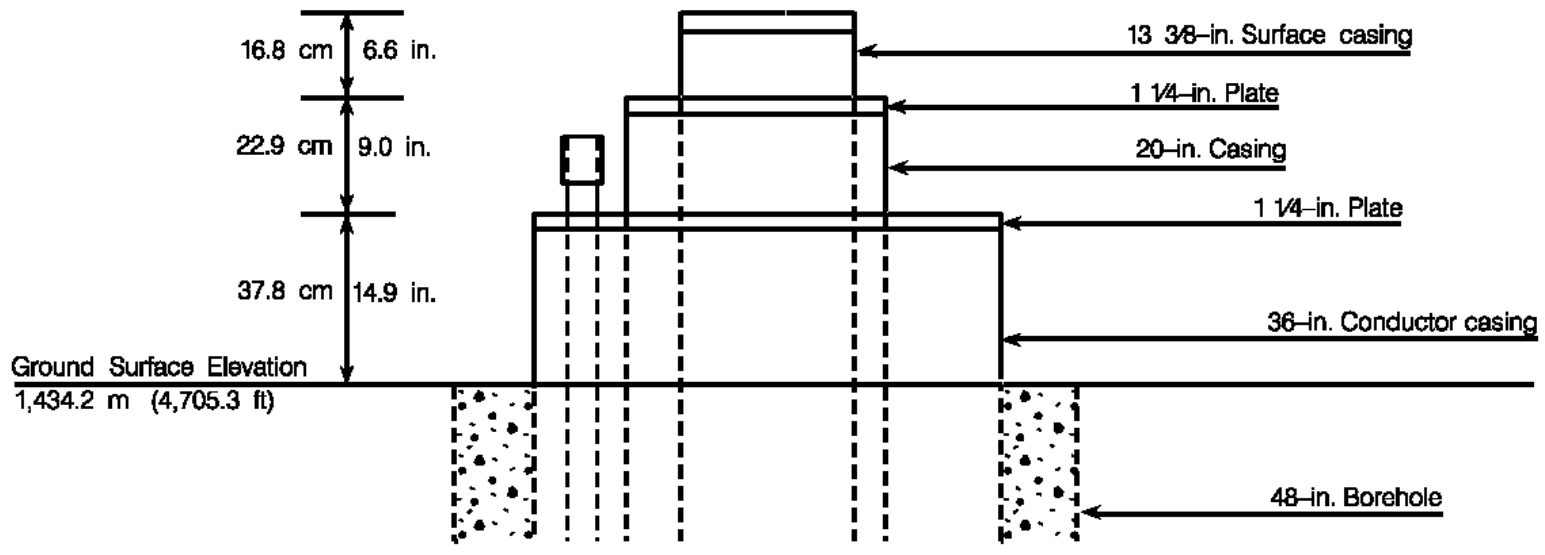

a NAD 83 Central Nevada State Plane Coordlnates

Figure 7-2

Wellhead Diagram for Well ER-12-2 


\section{Table 7-1}

\section{Well ER-12-2 Completion String Construction Summary}

\begin{tabular}{|c|c|c|c|c|}
\hline Tubing Type & \multicolumn{2}{|c|}{$\begin{array}{l}\text { Configuration } \\
\text { meters (feet) }\end{array}$} & $\begin{array}{c}\text { Cement } \\
\text { meters (feet) }\end{array}$ & $\begin{array}{l}\text { Sand/Gravel } \\
\text { meters (feet) }\end{array}$ \\
\hline \multirow{2}{*}{$\begin{array}{c}2 d \text {-in. Stainless- } \\
\text { Steel Tubing }\end{array}$} & \multirow{2}{*}{$\begin{array}{c}0 \text { to } 176.4 \\
\text { ( } 0 \text { to } 578.9 \text { ) }\end{array}$} & $\begin{array}{c}\text { Blank } \\
0 \text { to } 141.1 \\
\text { (0 to } 463.0)\end{array}$ & \multirow{2}{*}{ None } & \multirow{2}{*}{ None } \\
\hline & & $\begin{array}{c}\text { Slotted and bull-nosed } \\
141.1 \text { to } 176.4 \\
(463.0 \text { to } 578.9)\end{array}$ & & \\
\hline
\end{tabular}

positioned outside the $13 \mathrm{~d}$-in. intermediate casing, at a depth corresponding to the static water level within the UCCU. The bottom portion of this tubing string would have been gravel-packed and cemented in place. The primary goal of the proposed completion design was to provide groundwater production data from the LCA, and to provide access to groundwater in two locations within the UCCU for monitoring and sampling.

\subsubsection{As-Built Completion Design}

The design of the Well ER-12-2 completion was determined through consultation with members of the UGTA Technical Working Group, on the basis of onsite evaluation of data such as lithology and water production, drilling data, and data from various geophysical logs.

Figure 7-1 shows that the only completion string installed in Well ER-12-2 consists of a $2 \mathrm{~d}$-in. carbon-steel piezometer tube placed in the annular space between the 20-in. surface casing and the borehole wall at a depth of $176.4 \mathrm{~m}$ (578.9 ft). The tubing string includes 4 contiguous slotted joints in the interval 141.1 to $176.4 \mathrm{~m}$ ( 463.0 to $578.9 \mathrm{ft}$ ). The bottom of the tubing is bull-nosed, with a drain hole ("weep hole") approximately $0.32 \mathrm{~cm}(0.125$-in.) in size. The openings in each slotted tubing joint are $0.15 \mathrm{~cm}$ (0.059 in.) wide and $5.1 \mathrm{~cm}$ (2.0 in.) long; the slots are arranged in rows of 18, with rows staggered 10 degrees on 15.2 -cm (6.0-in.) centers.

\subsubsection{Rationale for Differences between Planned and Actual Well Design}

The proposed well completion design for Well ER-12-2 was based on the expectation that the well would penetrate through the UCCU and reach TD in the LCA. However, because the LCA was not encountered and no discrete water producing intervals were identified within the UCCU, no completion 


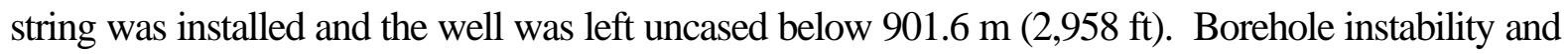
the inability to determine the static water table within the UCCU due to the use of heavy mud precluded the establishment of a piezometer string at the static water table within the UCCU as proposed. A piezometer string was installed to a depth of $176.4 \mathrm{~m}(578.9 \mathrm{ft})$ to access unanticipated perched water identified within the volcanic section during drilling.

\subsection{Well Completion Method}

The $2 \mathrm{~d}$-in. carbon-steel piezometer tube was inserted into the annular space outside the 20-in. surface casing on December 1, 2002, immediately after installation of the 20-in. casing, and before drilling of the 47.0-cm (18.5-in.) hole resumed. In the upper part of the annulus, above the bottom of the 30-in. conductor casing set at the depth of $35.6 \mathrm{~m}$ (116.8 ft), the tubing sits between the two casings. Below $36.3 \mathrm{~m} \mathrm{(119} \mathrm{ft),} \mathrm{which} \mathrm{is} \mathrm{the} \mathrm{cemented} \mathrm{portion} \mathrm{of} \mathrm{the} \mathrm{hole} \mathrm{below} \mathrm{the} \mathrm{surface} \mathrm{casing,} \mathrm{this} \mathrm{annular} \mathrm{space}$ is defined by the 20 -in casing and the borehole wall. All well construction materials were inspected according to relevant procedures; standard decontamination procedures were employed to prevent the introduction of contaminants into the well. No gravel-pack or cement was emplaced with the piezometer string.

No production casing was installed in the borehole, which remains open below the $13 \mathrm{~d}$-in. intermediate casing set at the depth of $901.6 \mathrm{~m}(2,958 \mathrm{ft})$. 
This page intentionally left blank. 


\subsection{Planned and Actual Costs and Scheduling}

The original BN cost model developed for Well ER-12-2 was based on drilling to the planned TD of $1,066.8 \mathrm{~m}(3,500 \mathrm{ft})$. The drilling program baseline projected that it would require 26 days to drill and complete the well. However, the actual conditions encountered during drilling of the well (borehole instability and much deeper than planned TD) were measurable different from the predicted conditions so the baseline was changed during drilling.

The new cost model is based on the actual TD of 2,097.9 $\mathrm{m}(6,883 \mathrm{ft})$. It took 55 days to drill the surface and main holes at Well ER-12-2. Drilling of the surface hole to the planned casing point at $613.0 \mathrm{~m}(2,011 \mathrm{ft})$ proceeded as expected. However, borehole obstructions encountered during geophysical logging required re-drilling to increase the hole diameter for installation of a larger diameter

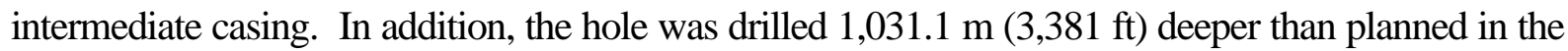
effort to tag the target lower carbonate aquifer rocks. Drilling did not reach the target formation, and the planned completion string was not installed. A graphical comparison, by day, of planned and actual well-construction activities is presented in Figure 8-1.

The cost analysis for Well ER-12-2 begins with construction of the conductor hole by BN and the cost of mobilizing the UDI drill rig to the Well ER-12-2 site. The cost of building roads, the drill pad, and sumps is not included, and the cost of well-site support by Shaw is not included. The total construction cost for Well ER-12-2 includes all drilling costs: charges by the drilling subcontractor; charges by other support subcontractors (including compressor services, drilling fluids, bits, casing services, down-hole tools, and geophysical logging); and charges by $\mathrm{BN}$ for mobilization and demobilization of equipment, partial construction of the conductor hole, cementing services, the piezometer string, radiation technicians, inspection services, and geotechnical consultation.

The total planned cost for constructing Well ER-12-2, based on the new baseline developed because the actual conditions differed greatly from the expected conditions, was $\$ 3,521,464$. The actual cost was $\$ 3,460,544$, or 1.7 percent less than the planned cost. Figure 8-2 presents a comparison of the planned (new baseline) and actual costs, by day, for constructing Well ER-12-2. 


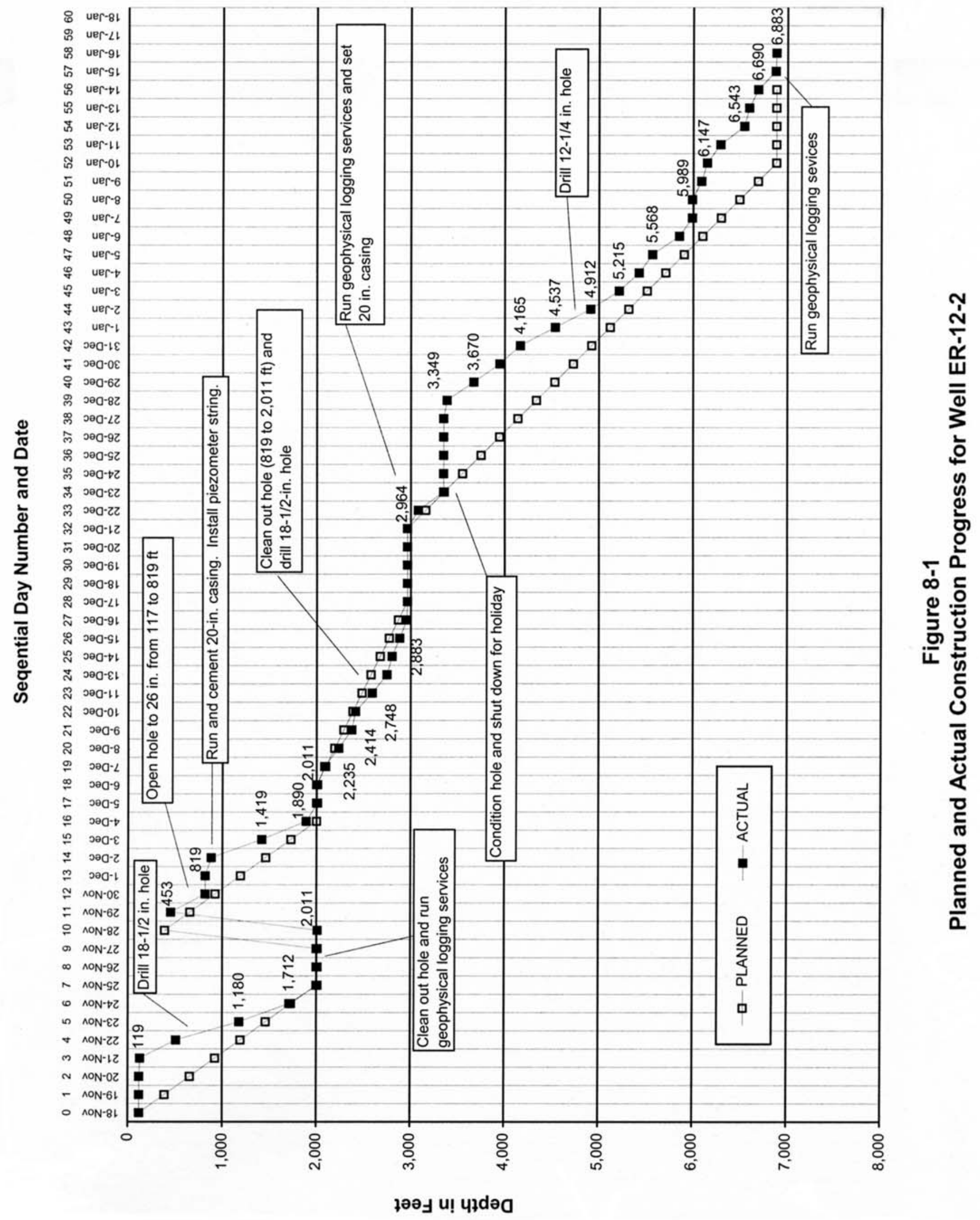




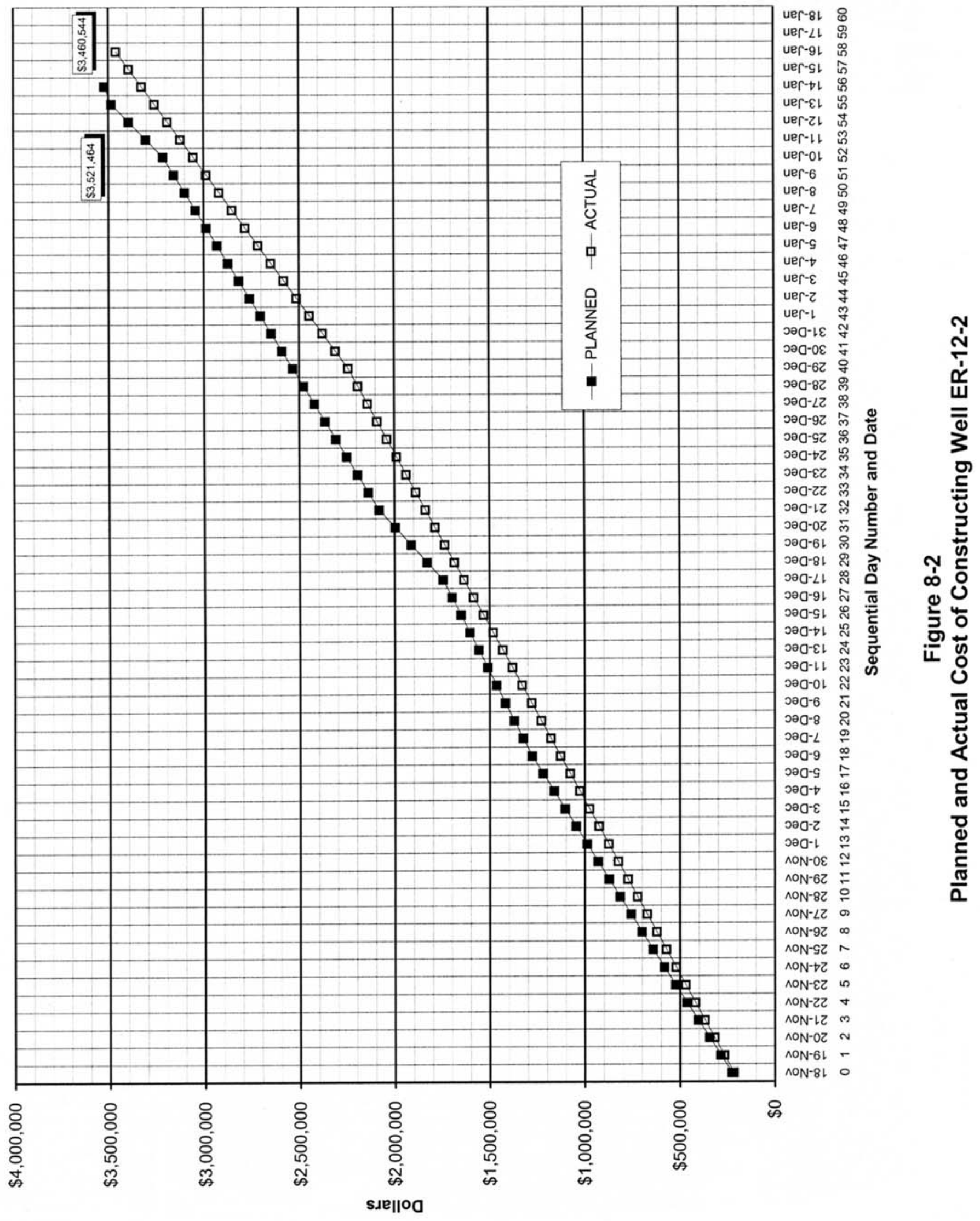


This page intentionally left blank. 


\subsection{Summary, Recommendations, and Lessons Learned}

\subsection{Summary}

Main hole drilling at Well ER-12-2 commenced on November 20, 2002, and concluded on January 15, 2003, at a total drilled depth of 2,097.9 m (6,883 ft). Sloughing of the borehole wall and intervals of swelling clays in the upper portions of the hole resulted in difficult drilling conditions and necessitated numerous borehole cleaning and conditioning efforts, setting an unplanned string of 20-in. surface casing, and using high viscosity mud as a circulating fluid while drilling from 613.0 to $903.4 \mathrm{~m}$ (2,011 to 2,964 ft). Very hard and abrasive rocks and borehole deviation caused slow drilling rates and excessive wear to down-hole drilling components during drilling of the lower portions of the well. The borehole deviated significantly from vertical, so that the bottom of the hole is located approximately $609.6 \mathrm{~m}(2,000 \mathrm{ft})$ north-northeast of the surface location at a true vertical depth of 1,896.2 m $(6,221 \mathrm{ft})$. Because the primary hydrogeologic target zone (i.e., LCA) was not encountered, the main completion string was not installed as planned and the well was left open below the base of the intermediate casing at $901.6 \mathrm{~m}(2,958 \mathrm{ft})$. A piezometer consisting of a string of $2 \mathrm{~d}$-in. slotted, carbon-steel tubing was placed outside of the 20-in. surface casing to a depth of $176.4 \mathrm{~m}$ (578.9 ft) to allow monitoring of perched water identified during drilling.

Geologic data collected during drilling included composite drill cuttings samples collected every $3 \mathrm{~m}$ $(10 \mathrm{ft})$ from $36.6 \mathrm{~m}$ (120 ft) to TD. In addition, 7 sidewall core samples were collected in the interval 790.7 to $1,208.8 \mathrm{~m}$ (2,594 to 3,966 ft). Geophysical logging was conducted in the upper portion of the borehole before installation of the surface casing, in the middle portion of the hole before installation of the intermediate casing string, and after TD of the well. Some of these logs were used to aid in construction of the well, while others help to verify the geology and determine the hydrologic characteristics of the rocks.

Well ER-12-2 is collared in young alluvial deposits, and penetrated $137.5 \mathrm{~m}$ (450 ft) of Quaternary and Tertiary alluvium before encountering $48.8 \mathrm{~m}$ (160 ft) of Tertiary volcanic rocks consisting of nonwelded to densely welded tuff. Below the volcanic rocks the well penetrated $289.6 \mathrm{~m}$ (950 ft) of Mississippian Chainman Shale. At a depth of $475.5 \mathrm{~m}$ (1,560 ft) the well encountered Mississippian and Upper Devonian Eleana Formation consisting of shale, argillite, sandstone, quartzite, and limestone. Drilling was terminated within the Eleana Formation at 2,097.9 m (6,883 ft) after penetrating 1,622.5 m $(5,323 \mathrm{ft})$ of the formation. The water level in the well was measured at $65.43 \mathrm{~m}(214.67 \mathrm{ft})$ on March 3, 2003. Tritium levels in the drilling fluid ranged from 0 to 3,262 picocuries per liter during drilling, 
which is at or below background levels. No other radionuclides above background were encountered in the drilling fluids from Well ER-12-2.

\section{$9.2 \quad$ Recommendations}

Additional geologic analyses that are pending or in progress should be completed. These analyses include petrographic, paleontological, and a detailed structural and stratigraphic analysis of the Electric Micro Imager log. The results from these analyses should be integrated with existing geologic interpretations of the well to form a detailed geologic characterization of Well ER-12-2 that is as complete as possible. The geologic data from the well should be integrated with the proposed magnetotelluric survey of Yucca Flat, and used as a "tie-point" for the survey.

All the geologic and hydrologic data and interpretations from Well ER-12-2 should be integrated into the hydrostratigraphic framework model of Yucca Flat. This will allow for more precise characterization of groundwater flow direction and velocity in the northwestern portion of Yucca Flat.

\subsection{Lessons Learned}

The efficiency of drilling and constructing wells to obtain hydrogeologic data in support of the UGTA project continues to improve as experience is gained with each new well. Sometimes difficult drilling conditions are encountered and challenges are confronted. Several new lessons were learned during the construction of Well ER-12-2, the third well in the FY 2003 Yucca Flat drilling initiative.

- The Chainman Shale includes intervals of swelling clays that caused borehole instability and tight hole conditions during drilling of this unit in Well ER-12-2. The Chainman Shale should be drilled with bentonite mud to provide borehole stability and control swelling clays. The formation should also be cased off before switching back to air/foam as a circulating fluid.

- The Eleana Formation contains intervals of very hard and abrasive quartzite that can significantly slow drilling rates and cause excessive wear to components of the BHA.

- Significant borehole deviation can occur when drilling thick sections of hard and moderately to steeply dipping Paleozoic formations such as the Eleana Formation. Borehole deviation should be monitored and the configuration of the BHA evaluated during drilling in such situations.

- Decentralizers on sidewall coring tools may need to be modified in deviated boreholes so core barrels can reach the borehole wall. 


\subsection{References}

Bechtel Nevada, 2001. Underground Testing Area (UGTA) Project Health and Safety Plan, January, 2001. Las Vegas, NV.

Bechtel Nevada, 2002. Plan for Main-Hole Drilling and Completion of Underground Test Area (UGTA) Investigation Well ER-12-2 - Original. Field Activity Work Plan Number D-010-002.03. Las Vegas, NV.

BN, see Bechtel Nevada.

Cashman, P. H. and J. H. Trexler, 1991. "The Mississippian Antler Foreland and Continental Margin in Southern Nevada: the Eleana Formation Reinterpreted." in Cooper, J. D. and C. H Stevens, eds., 1991. Paleozoic Paleogeography of the Western United States - II. Pacific Section SEPM, Vol. 67, p. 271-280.

Cole, J. C., and P. H. Cashman, 1999. Structural Relationships of Pre-Tertiary Rocks in the Nevada Test Site Region, Southern Nevada. U.S. Geological Survey Professional Paper 1607.

Cole, J. C., A. G. Harris, and R. R. Wahl, 1997. "Subcrop Geologic Map of Pre-Tertiary Rocks in the Yucca Flat and Northern Frenchman Flat Areas, Nevada Test Site, Southern Nevada." U.S. Geological Survey Open-File Report 97-678, scale 1:48,000, Denver, CO.

DOE/NV, see U.S. Department of Energy.

Gibbons, A. B., E. N. Hinrichs, W. R. Hansen, and R. W. Lemke, 1963. Geology of the Rainier Mesa Quadrangle, Nye County, Nevada. U.S. Geological Survey Map GQ-215.

Gonzales, J. L., S. L. Drellack, and M. J. Townsend, 1998. Written communication prepared in support of the UGTA project. Subject: "Descriptive Narrative for the Hydrogeologic Model at the Yucca Flat Corrective Action Unit.” An interim report. Bechtel Nevada, Las Vegas, NV.

Gonzales, J. L., and S. L. Drellack, 1999. Written communication prepared in support of the UGTA project. Subject: "Addendum to the Descriptive Narrative for the Hydrogeologic Model of the Yucca Flat Corrective Action Unit: Northern Extension.” Bechtel Nevada, Las Vegas, NV.

IT, see IT Corporation.

IT Corporation, 2002. Yucca Flat Hydrogeologic Investigation Wells Drilling and Completion Criteria, ITLV/13052-164. Las Vegas, NV.

Nevada Bureau of Mines and Geology, 1997. County Digital Geologic Mapping Project - Final Report. Open-File Report 97-1, scale 1:250,000. 
Poole, F. G., F. N. Houser, and P. P. Orkild, 1961. Eleana Formation of Nevada Test Site and Vicinity, Nye County, Nevada. U.S. Geological Survey Professional Paper 424-D, p. D104-D111.

Sawyer, D. A., J. J. Fleck, M. A. Lanphere, R. G. Warren, and D. E. Broxton, 1994. "Episodic Caldera Volcanism in the Miocene Southwest Nevada Volcanic Field: Revised Stratigraphic Caldera Framework, 40Ar/39Ar Geochronology, and Implications for Magmatism and Extension." Geological Society of America Bulletin, v. 67, n. 10, p. 1,304-1,318.

Shaw, see Shaw Environmental, Inc.

Shaw Environmental, Inc, 2003. Written communication prepared for NNSA/NSO. Subject: "ER 122 Well Data Report," July 23, 2003. Las Vegas, NV.

Slate, J. L., M. E. Berry, P. D., Rowley, C. J. Fridrich, K. S. Morgan, J. B. Workman, O. D. Young, G. L. Dixon, V. S. Williams, E. H. McKee, D. A. Ponce, T. G. Hildenbrand, WC Swadley, S. C. Lundstrom, E. B. Ekren, R. G. Warren, J. C. Cole, R. J. Fleck, M. A. Lanphere, D. A. Sawyer, S. A. Minor, D. J. Grunwald, R. J. Laczniak, C. M. Menges, J. C. Yount, and A. S. Jayko, 1999. Digital Geologic Map of the Nevada Test Site and Vicinity, Nye, Lincoln, and Clark Counties, Nevada, and Inyo County, California. U.S. Geological Survey Open-File Report 99-554-A.

Trexler, J. H., J. C. Cole, and P. H. Cashman, 1996. Devonian-Mississippian Stratigraphy On and Near the Nevada Test Site: Implications for Hydrocarbon Potential. American Association of Petroleum Geologists Bulletin, Volume 80, Number 11, p. 1,736 - 1,762.

U.S. Department of Energy, Nevada Operations Office, 2002a. Attachment 1, "Fluid Management Plan for the Underground Test Area Project, Rev. 3," DOE/NV--370. Las Vegas, NV.

U.S. Department of Energy, Nevada Operations Office, 2002b. Underground Test Area (UGTA) Waste Management Plan. DOE/NV--343-Rev. 2. Las Vegas, NV.

WoldeGrabriel, G., S. Chipera, G. Keating, E. Kluk, S. Levy, and P. Snow, 2003. Personal communication to L. B. Prothro, Bechtel Nevada. Subject: Preliminary Geological Characterization of Well ER-12-2, Yucca Flat, Nevada Test Site.

Wycoff, R. C., U.S. Department of Energy, National Nuclear Security Administration Nevada Operations Office. 2002. Letter to P. J. Liebendorfer, Nevada Division of Environmental Protection. Subject: "Well-Site Fluid Management Strategy, DOE NNSA/NV Yucca Flat Drilling Program, Nevada Test Site, Well ER-12-2,” June 26, 2002. Las Vegas, NV. 


\section{Appendix A \\ Drilling Data}

A-1 Drilling Parameter Log for Well ER-12-2

A-2 Casing Data for Well ER-12-2

A-3 Well ER-12-2 Drilling Fluids and Cement Composition 
Appendix A-1

Drilling Parameter Log for Well ER-12-2 


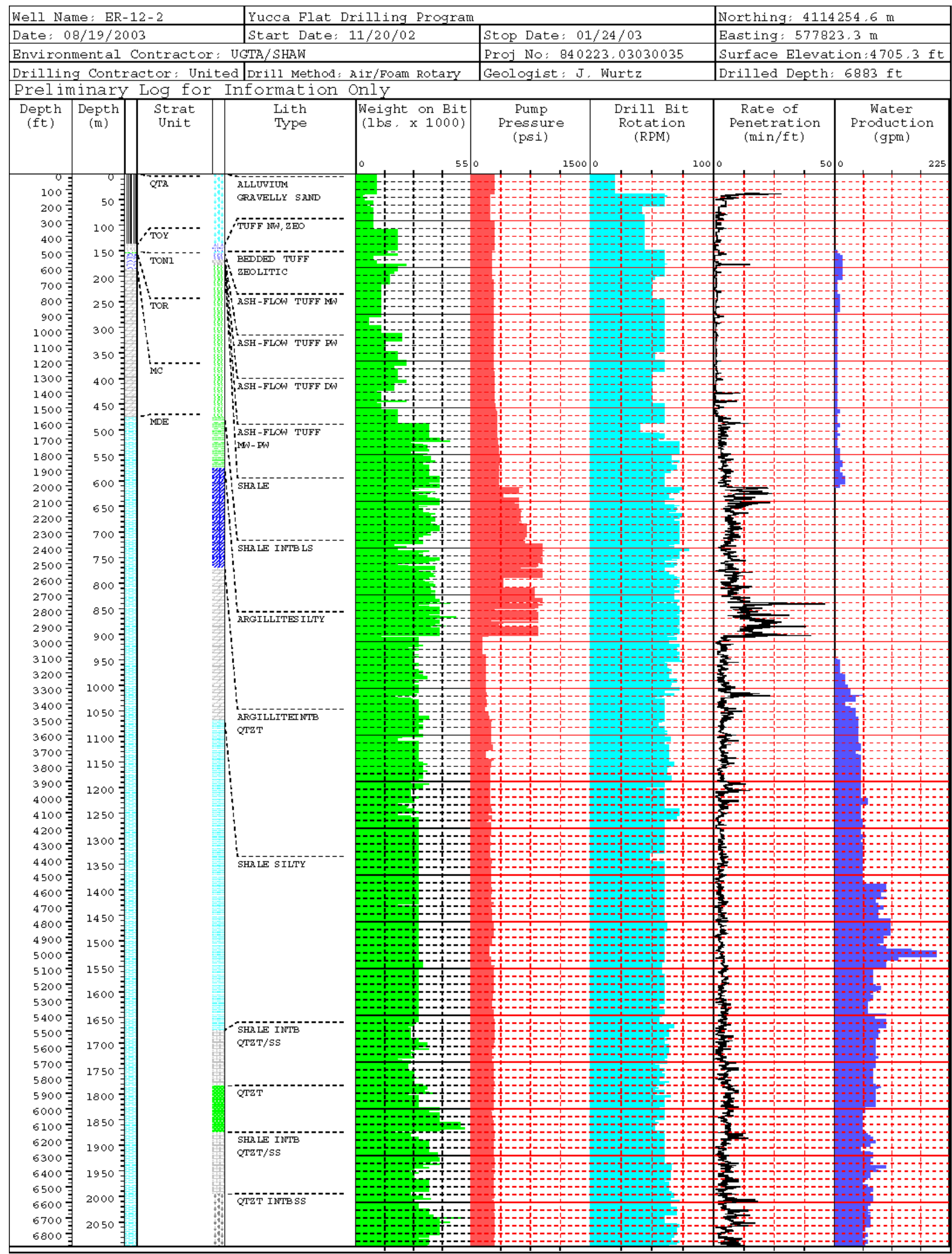


This page intentionally left blank.

A-1-2 
Appendix A-2

Casing Data for Well ER-12-2 
Table A-2

Casing Data for Well ER-12-2

\begin{tabular}{||c|c|c|c|c|c|c|c||}
\hline Casing & $\begin{array}{c}\text { Depth Interval } \\
\text { meters } \\
\text { (feet) }\end{array}$ & Type & Grade & $\begin{array}{c}\text { Outside } \\
\text { Diameter } \\
\text { centimeters } \\
\text { (inches) }\end{array}$ & $\begin{array}{c}\text { Inside } \\
\text { Diameter } \\
\text { centimeters } \\
\text { (inches) }\end{array}$ & $\begin{array}{c}\text { Wall } \\
\text { Thickness } \\
\text { centimeters } \\
\text { (inches) }\end{array}$ & $\begin{array}{c}\text { Weight } \\
\text { per } \\
\text { foot } \\
\text { (pounds) }\end{array}$ \\
\hline Conductor & $\begin{array}{c}\text { 0 to } 35.6 \\
\text { (0 to } 116.8)\end{array}$ & $\begin{array}{c}\text { Carbon Steel } \\
\text { PE Weld }\end{array}$ & $\mathrm{N} / \mathrm{A}$ & $\begin{array}{c}76.2 \\
(30)\end{array}$ & $\begin{array}{c}74.295 \\
(29.0)\end{array}$ & $\begin{array}{c}1.27 \\
(0.5)\end{array}$ & 157.45 \\
\hline Surface & $\begin{array}{c}0 \text { to } 246.6 \\
(0 \text { to } 809.1)\end{array}$ & Carbon Steel & K-55 & $\begin{array}{c}50.8 \\
(20)\end{array}$ & $\begin{array}{c}48.6 \\
(19.124)\end{array}$ & $\begin{array}{c}1.9 \\
(0.876)\end{array}$ & 94 \\
\hline Intermediate & $\begin{array}{c}0 \text { to } 716.0 \\
(0 \text { to } 2,349.1)\end{array}$ & Carbon Steel & J-55 & $\begin{array}{c}33.97 \\
(13.375)\end{array}$ & $\begin{array}{c}31.79 \\
(12.515)\end{array}$ & $\begin{array}{c}1.09 \\
(0.43)\end{array}$ & 61 \\
\hline Intermediate & $\begin{array}{c}716.0 \text { to } 901.6 \\
(2,349.1 \text { to } 2,958.2)\end{array}$ & Carbon Steel & J-55 & $\begin{array}{c}33.97 \\
(13.375)\end{array}$ & $\begin{array}{c}31.53 \\
(12.415)\end{array}$ & $\begin{array}{c}2.44 \\
(0.53)\end{array}$ & 68 \\
\hline Piezometer & $\begin{array}{l}0 \text { to } 176.4 \\
(0 \text { to } 578.9)\end{array}$ & Carbon Steel & $\mathrm{N} / \mathrm{A}$ & $\begin{array}{c}6.03 \\
(2.375)\end{array}$ & $\begin{array}{c}4.94 \\
(1.945)\end{array}$ & $\begin{array}{c}1.09 \\
(0.43)\end{array}$ & 4.6 \\
\hline
\end{tabular}


This page intentionally left blank.

A-2-2 


\section{Appendix A-3 \\ Well ER-12-2 Drilling Fluids and Cement Composition}


Table A-3-1

Drilling Fluids Used in Well ER-12-2

\begin{tabular}{||c|c||}
\hline Typical Air-Foam/Polymer Mix & Typical Bentonite Mud Mix $^{\text {a }}$ \\
\hline \hline $\begin{array}{c}\text { 56.8 to 113.5 liters (15 to } 30 \text { gallons) Geofoam }{ }^{\circledR a} \\
\text { 3.8 to } 18.9 \text { liters (1 to } 5 \text { gallons) LP-701 }{ }^{\circledR a}\end{array}$ \\
0.5 to 2 liters of LiBr \\
per \\
7,949 liters (50 barrels) water
\end{tabular}

a $\quad$ Geofoam ${ }^{\circledR}$ foaming agent, LP- $701{ }^{\circledR}$ polymer additive, and Geo Gel ${ }^{\circledR}$ bentonite mud are products of Geo Drilling Fluids, Inc.

NOTES:

1. All water used to mix drilling fluids for Well ER-12-2 came from Water Well UE16-d in Yucca Flat.

2. A concentrated solution of lithium bromide was added to all introduced fluids to make up a final concentration of 20 to 60 milligrams per liter.

Table A-3-2

Well ER-12-2 Cement Composition

\begin{tabular}{||c|c|c|c|c|c|c||}
\hline \multirow{2}{*}{$\begin{array}{c}\text { Cement } \\
\text { Composition }\end{array}$} & \multicolumn{2}{|c|}{$\begin{array}{c}\text { 30-inch } \\
\text { Conductor Casing }\end{array}$} & \multicolumn{2}{c|}{$\begin{array}{c}\text { 20-inch } \\
\text { Surface Casing }\end{array}$} & \multicolumn{2}{c||}{$\begin{array}{c}\text { 13d -inch } \\
\text { Intermediate Casing }\end{array}$} \\
\cline { 2 - 7 } & Interval & Amount & Interval & Amount & Interval & Amount \\
\hline \hline $\begin{array}{c}\text { Type II, first stage } \\
\text { with aggregate, } \\
\text { remaining stages } \\
\text { with sand }\end{array}$ & $\begin{array}{c}0 \text { to } 36.6 \mathrm{~m}^{\mathrm{a}} \\
\left(0 \mathrm{to} 120 \mathrm{ft}^{\mathrm{b}}\right)\end{array}$ & $\begin{array}{c}40.9 \mathrm{~m}^{3 \mathrm{c}} \\
\left(1,444.5 \mathrm{ft}^{3}\right)^{\mathrm{d}}\end{array}$ & Not used & -- & Not used & -- \\
\hline Type II neat & Not used & -- & $\begin{array}{c}\text { Not } \\
\text { measured }\end{array}$ & $\begin{array}{c}8.5 \mathrm{~m}^{3} \\
\left(300 \mathrm{ft}^{3}\right)\end{array}$ & mot & $\begin{array}{c}\text { measured } \\
\left(350 \mathrm{ft}^{3}\right)\end{array}$ \\
\hline
\end{tabular}
a $\operatorname{meter}(\mathrm{s})$
b foot (feet)
c cubic meters
d cubic feet 
This page intentionally left blank.

A-3-2 


\section{Appendix B \\ Well ER-12-2 Fluid Management Data}




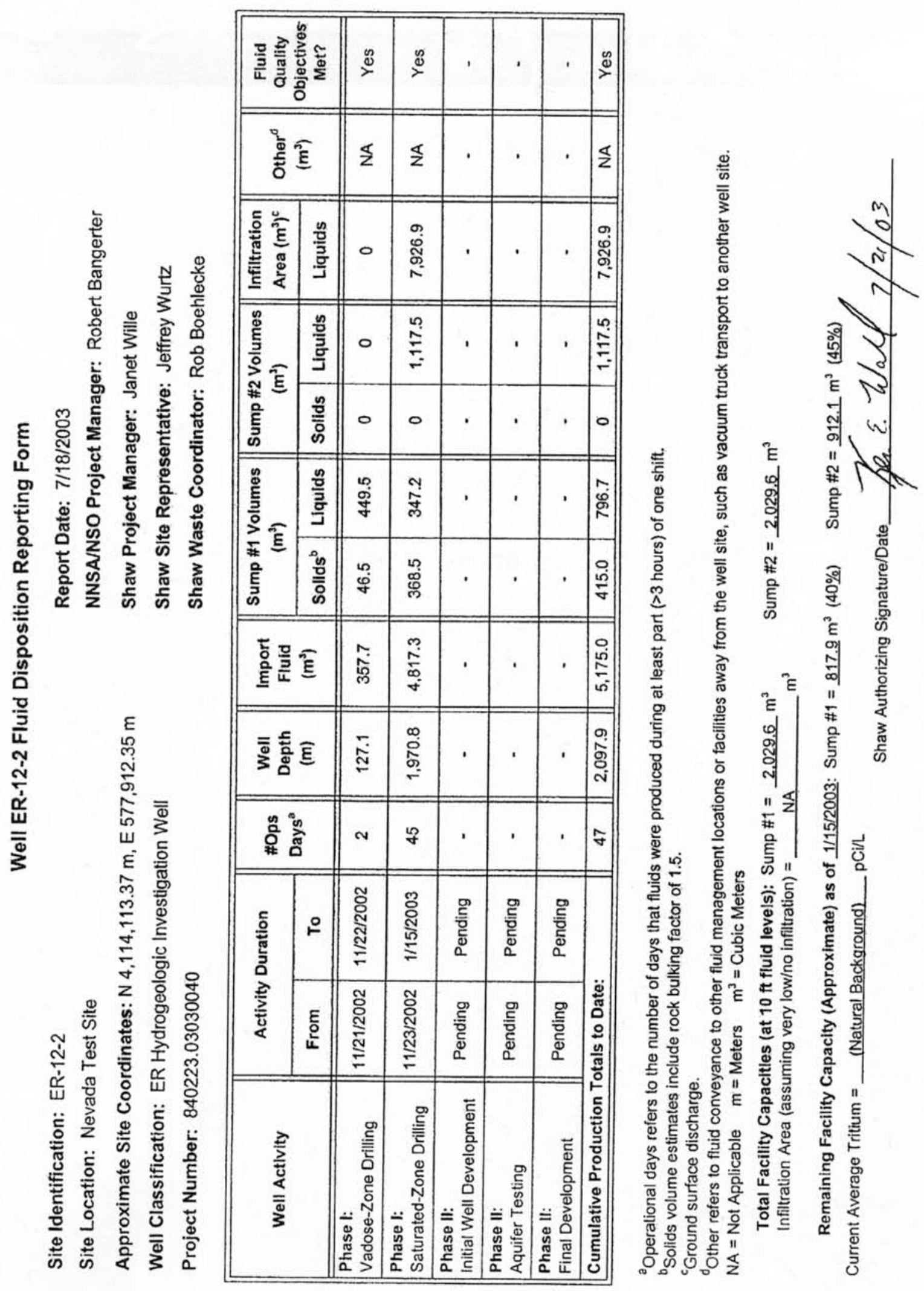


This page intentionally left blank.

B-2 
Appendix C

Detailed Lithologic Log for Well ER-12-2 


\section{Detailed Lithologic Log for Well ER-12-2}

Logged by Lance Prothro, Bechtel Nevada

March 2003

\begin{tabular}{|c|c|c|c|c|c|}
\hline $\begin{array}{c}\text { Depth } \\
\text { Interval } \\
\text { meters } \\
\text { (feet) } \\
\end{array}$ & $\begin{array}{c}\text { Thickness } \\
\text { meters } \\
\text { (feet) }\end{array}$ & $\begin{array}{l}\text { Sample } \\
\text { Type }{ }^{1}\end{array}$ & $\begin{array}{l}\text { Laboratory } \\
\text { Analyses }^{2}\end{array}$ & Lithologic Description ${ }^{3}$ & $\begin{array}{c}\text { Stratigraphic } \\
\text { Unit }\end{array}$ \\
\hline $\begin{array}{l}0-137.2 \\
(0-450)\end{array}$ & $\begin{array}{l}137.2 \\
(450)\end{array}$ & DB1 & $\begin{array}{c}\text { PTS, } \\
\text { XRD, XRF, } \\
\mathrm{Fe}^{2+} / \mathrm{Fe}^{3+}\end{array}$ & $\begin{array}{l}\text { Alluvium: Drill cuttings samples consist of loose mixtures of the } \\
\text { harder clasts from within the alluvium. Clasts were liberated from the } \\
\text { alluvium and concentrated in the samples as a result of the drilling } \\
\text { and sample collection processes, indicating that the alluvium is } \\
\text { poorly consolidated. Clasts are predominately moderate-yellowish- } \\
\text { brown (10YR 5/4) sandstone, quartzite, and chert-pebble } \\
\text { conglomerate typical of the Eleana Formation that compose much of } \\
\text { the highlands north and west of Well ER-12-2. Lesser amounts of } \\
\text { tuffaceous clasts are also present in the samples. Tuffaceous rocks } \\
\text { are also present in the highlands north and west of the well. Most of } \\
\text { the clasts show some degree of rounding indicating transport from a } \\
\text { source area. Many clasts are partially coated with a thin, light-brown } \\
\text { (5YR } 5 / 6) \text {, fine- to medium-grained calcareous material that probably } \\
\text { represents the alluvial matrix. This matrix material has a tuffaceous } \\
\text { character due to the presence of biotite, small fragments of pumice, } \\
\text { and felsic minerals. The electric micro imaging log indicates the } \\
\text { interval is very bedded. }\end{array}$ & $\begin{array}{c}\text { Quaternary } \\
\text { and Tertiary } \\
\text { Alluvium }\end{array}$ \\
\hline $\begin{array}{c}137.2-143.3 \\
(450-470)\end{array}$ & $\begin{array}{l}6.1 \\
(20)\end{array}$ & DB4 & $\begin{array}{c}\text { PTS, } \\
\text { XRD, XRF, } \\
\mathrm{Fe}^{2+} / \mathrm{Fe}^{3+}\end{array}$ & $\begin{array}{l}\text { Nonwelded Tuff: Pale-yellowish-brown (10YR 6/2); zeolitic; } \\
\text { common grayish-yellow (10YR 7/4) and very-pale-orange (10YR 8/2) } \\
\text { pumice; common felsic phenocrysts of feldspar and lesser quartz; } \\
\text { abundant mafic minerals of black (N1) and slightly bronze-colored } \\
\text { biotite and much less hornblende that appears to be partially to } \\
\text { completely altered to magnetite(?); rare lithic fragments. }\end{array}$ & $\begin{array}{c}\text { Yucca Flat } \\
\text { Tuff }\end{array}$ \\
\hline
\end{tabular}




\begin{tabular}{|c|c|c|c|c|c|}
\hline $\begin{array}{l}\text { Depth } \\
\text { Interval } \\
\text { meters } \\
\text { (feet) } \\
\end{array}$ & $\begin{array}{l}\text { Thickness } \\
\text { meters } \\
\text { (feet) }\end{array}$ & $\begin{array}{l}\text { Sample } \\
\text { Type } 1\end{array}$ & $\begin{array}{l}\text { Laboratory } \\
\text { Analyses }^{2}\end{array}$ & Lithologic Description ${ }^{3}$ & $\begin{array}{c}\text { Stratigraphic } \\
\text { Unit }\end{array}$ \\
\hline $\begin{array}{c}143.3-151.8 \\
(470-498)\end{array}$ & $\begin{array}{l}8.5 \\
(28)\end{array}$ & DB4 & $\begin{array}{l}\text { PTS, MP, } \\
\text { XRD }\end{array}$ & $\begin{array}{l}\text { Nonwelded Tuff: Yellowish-gray ( } 5 Y \text { Y } 8 / 1 \text { ); mostly zeolitic, partially } \\
\text { calcic and argillic (?); rapidly disintegrates when placed in water; } \\
\text { pumice fragments are difficult to discern but appear to be minor in } \\
\text { abundance; minor felsic phenocrysts of feldspar and lesser quartz; } \\
\text { common to abundant mafic minerals of black (N1) to bronze-colored } \\
\text { biotite and much less hornblende; very rare lithic fragments. }\end{array}$ & $\begin{array}{c}\text { Yucca Flat } \\
\text { Tuff }\end{array}$ \\
\hline $\begin{array}{c}151.8-156.1 \\
(498-512)\end{array}$ & $\begin{array}{c}4.3 \\
(14)\end{array}$ & DB4 & $\begin{array}{c}\text { PTS, } \\
\text { XRD, XRF, } \\
\mathrm{Fe}^{2+} / \mathrm{Fe}^{3+}\end{array}$ & $\begin{array}{l}\text { Bedded Tuff: Yellowish-gray (5Y 8/1); zeolitic; equigranular texture; } \\
\text { very abundant small fragments of pumice; very abundant felsic } \\
\text { phenocrysts of feldspar and quartz; abundant mafic minerals of black } \\
\text { (N1) to bronze-colored biotite and much less hornblende; rare lithic } \\
\text { fragments. }\end{array}$ & tunnel bed 1 \\
\hline $\begin{array}{c}156.1-167.6 \\
(512-550)\end{array}$ & $\begin{array}{l}11.6 \\
(38)\end{array}$ & DA & $\begin{array}{c}\text { PTS, MP } \\
\text { XRD, XRF, } \\
\mathrm{Fe}^{2+} / \mathrm{Fe}^{3+}\end{array}$ & $\begin{array}{l}\text { Moderately Welded Ash-Flow Tuff: Light-brownish-gray (5YR 6/1) } \\
\text { and pale-red (5R } 6 / 2) \text {; silicic; minor flattened pumice; minor felsic } \\
\text { phenocrysts of feldspar and lesser quartz; minor mafic minerals of } \\
\text { biotite and slightly less partially to completely altered hornblende; } \\
\text { very rare lithic fragments. }\end{array}$ & \\
\hline $\begin{array}{c}167.6-173.7 \\
(550-570)\end{array}$ & $\begin{array}{l}6.1 \\
(20)\end{array}$ & DA & $\begin{array}{c}\text { PTS, MP } \\
\text { XRD, XRF, } \\
\mathrm{Fe}^{2+} / \mathrm{Fe}^{3+}\end{array}$ & $\begin{array}{l}\text { Partially Welded Ash-Flow Tuff: Pale-yellowish-brown (10YR 6/2); } \\
\text { weak to moderate quartzo-feldspathic alteration; rare to minor } \\
\text { corroded and replaced pumice; minor felsic phenocrysts of feldspar } \\
\text { and much less quartz (?), feldspar phenocrysts show varying } \\
\text { degrees of alteration with many partially to completely corroded } \\
\text { away; common to abundant, mostly altered mafic minerals of biotite } \\
\text { and lesser hornblende; rare lithic fragments. }\end{array}$ & $\begin{array}{c}\text { Redrock Valley } \\
\text { Tuff }\end{array}$ \\
\hline
\end{tabular}




\begin{tabular}{|c|c|c|c|c|c|}
\hline $\begin{array}{c}\text { Depth } \\
\text { Interval } \\
\text { meters } \\
\text { (feet) } \\
\end{array}$ & $\begin{array}{c}\text { Thickness } \\
\text { meters } \\
\text { (feet) }\end{array}$ & $\begin{array}{l}\text { Sample } \\
\text { Type }\end{array}$ & $\begin{array}{l}\text { Laboratory } \\
\text { Analyses }\end{array}$ & Lithologic Description ${ }^{3}$ & $\begin{array}{c}\text { Stratigraphic } \\
\text { Unit }\end{array}$ \\
\hline $\begin{array}{c}173.7-179.8 \\
(570-590)\end{array}$ & $\begin{array}{c}6.1 \\
(20)\end{array}$ & DB4 & $\begin{array}{c}\text { PTS, MP } \\
\text { XRD, XRF, } \\
\mathrm{Fe}^{2+} / \mathrm{Fe}^{3+}\end{array}$ & $\begin{array}{l}\text { Densely Welded Ash-Flow Tuff: Dark-yellowish-brown (10YR 4/2) } \\
\text { to moderate-yellowish-brown (10YR 5/4); quartzo-feldspathic } \\
\text { alteration; minor highly flattened, moderate-brown (5YR 3/4) pumice; } \\
\text { minor to common felsic phenocrysts of feldspar and lesser quartz, } \\
\text { with many feldspar phenocrysts partially to completely altered; } \\
\text { original abundance of mafic minerals is difficult to ascertain due to } \\
\text { degree of alteration, but appears to have been at least common in } \\
\text { abundance, rare unaltered biotite is present; rare lithic fragments. } \\
\text { Many fragments show brecciation with secondary botryoidal } \\
\text { chalcedony (var. agate) lining and filling openings. }\end{array}$ & \multirow{2}{*}{$\begin{array}{c}\text { Redrock Valley } \\
\text { Tuff }\end{array}$} \\
\hline $\begin{array}{c}179.8-185.9 \\
(590-610)\end{array}$ & $\begin{array}{c}6.1 \\
(20)\end{array}$ & DB4 & $\begin{array}{c}\text { PTS, MP } \\
\text { XRD, XRF } \\
\mathrm{Fe}^{2+} / \mathrm{Fe}^{3+}\end{array}$ & $\begin{array}{l}\text { Moderately to Partially Welded Ash-Flow Tuff: Moderate- } \\
\text { yellowish-brown (5YR 5/4) to pale-yellowish-brown (10YR 6/2); } \\
\text { quartzo-feldspathic alteration; minor dark-yellowish-brown (10YR 4/2) } \\
\text { flattened pumice that gives rock a conspicuous eutaxitic fabric; } \\
\text { minor to common felsic phenocrysts of feldspar, some partially to } \\
\text { completely altered, and lesser quartz; original abundance of mafic } \\
\text { minerals is difficult to ascertain due to degree of alteration, but } \\
\text { appears to have been no greater than common, biotite is certainly } \\
\text { present but is strongly altered where discernable; rare to minor lithic } \\
\text { fragments. }\end{array}$ & \\
\hline $\begin{array}{l}185.9-475.5 \\
(610-1,560)\end{array}$ & $\begin{array}{l}289.6 \\
(950)\end{array}$ & DA & $\begin{array}{c}\text { PTS } \\
\text { XRD, XRF, } \\
\mathrm{Fe}^{2+} / \mathrm{Fe}^{3+}\end{array}$ & $\begin{array}{l}\text { Shale: Moderate-brown (5YR 4/4) to dusky-yellowish-brown (10YR } \\
\text { 2/2) to approximately } 213.4 \mathrm{~m}(700 \mathrm{ft}) \text {, grayish-black (N2) to black } \\
\text { (N1) below; brownish color in upper part is due to the presence of iron } \\
\text { oxides that coat fragments, particularly along shale partings; poorly } \\
\text { to moderately indurated; weakly to moderately fissile; weakly } \\
\text { calcareous; sparse pyrite occurs throughout interval and appears } \\
\text { associated with bedding planes, shale partings, and fractures. }\end{array}$ & ChainmanShale \\
\hline
\end{tabular}




\begin{tabular}{|c|c|c|c|c|c|}
\hline $\begin{array}{c}\text { Depth } \\
\text { Interval } \\
\text { meters } \\
\text { (feet) } \\
\end{array}$ & $\begin{array}{l}\text { Thickness } \\
\text { meters } \\
\text { (feet) }\end{array}$ & $\begin{array}{l}\text { Sample } \\
\text { Type } 1\end{array}$ & $\begin{array}{l}\text { Laboratory } \\
\text { Analyses }\end{array}$ & Lithologic Description ${ }^{3}$ & $\underset{\text { Unit }}{\text { Stratigraphic }}$ \\
\hline $\begin{array}{c}475.5-576.1 \\
(1,560-1,890)\end{array}$ & $\begin{array}{l}100.6 \\
(330)\end{array}$ & DA & PTS, XRD & $\begin{array}{l}\text { Interbedded Shale and Limestone: Shale is black (N1); silty; well } \\
\text { indurated; occurs mostly as hard blocky fragments, rarely weakly } \\
\text { fissile; very weakly calcareous in part; rare pyrite as very fine crystal } \\
\text { aggregates. The high degree of induration and hard, blocky character } \\
\text { of many fragments suggest that much of the shale may classify as } \\
\text { argillite. Limestone is dark-gray (N3) to grayish-black (N2); } \\
\text { bioclastic, consisting mostly of coarse-grained recrystallized } \\
\text { limestone clasts including fossil fragments; rare fine- to medium- } \\
\text { grained, rounded quartz grains and subrounded chert fragments; } \\
\text { cement appears to be a combination of sparry calcite, silica, and } \\
\text { argillaceous material; rare to common pyrite as fine disseminated } \\
\text { crystals and as coarser aggregates partially replacing fossil } \\
\text { fragments. } \\
\text { Overall, the interval consists of approximately } 60 \% \text { shale and } 40 \% \\
\text { limestone, however the bottom } 24.4 \mathrm{~m} \text { ( } 80 \text { ft) of the interval is } \\
\text { approximately } 90 \text { percent limestone and } 10 \text { percent thin shale beds. } \\
\text { The abrupt nature of the upper contact as observed on geophysical } \\
\text { logs and drilling rate charts, the indication of fractures on the spectral } \\
\text { gamma ray log at the contact, and the abrupt change in the lithologic } \\
\text { character of shale at the contact suggests the upper contact may be } \\
\text { a fault. }\end{array}$ & $\begin{array}{l}\text { Eleana } \\
\text { Formation }\end{array}$ \\
\hline $\begin{array}{c}576.1-771.1 \\
(1,890-2,530)\end{array}$ & $\begin{array}{l}195.0 \\
(640)\end{array}$ & DA & None & $\begin{array}{l}\text { Argillite: Black (N1); silty; well to very well indurated; occurs as } \\
\text { hard, blocky fragments with no fissility; degree of induration and } \\
\text { hardness appears to increase with depth. }\end{array}$ & \\
\hline
\end{tabular}




\begin{tabular}{|c|c|c|c|c|c|}
\hline $\begin{array}{c}\text { Depth } \\
\text { Interval } \\
\text { meters } \\
\text { (feet) } \\
\end{array}$ & $\begin{array}{l}\text { Thickness } \\
\text { meters } \\
\text { (feet) }\end{array}$ & $\begin{array}{l}\text { Sample } \\
\text { Type } 1\end{array}$ & $\begin{array}{l}\text { Laboratory } \\
\text { Analyses }^{2}\end{array}$ & Lithologic Description ${ }^{3}$ & $\begin{array}{c}\text { Stratigraphic } \\
\text { Unit }\end{array}$ \\
\hline $\begin{array}{l}771.1-1,069.2 \\
(2,530-3,508)\end{array}$ & $\begin{array}{l}298.1 \\
(978)\end{array}$ & $\mathrm{DA}, \mathrm{SC}$ & PTS, XRD & $\begin{array}{l}\text { Interbedded Quartzite and lesser Argillite: Quartzite is dark-gray } \\
\text { (N3) to grayish-black (N2); very well indurated; mostly fine-grained, } \\
\text { lesser medium-grained, and much less conglomeratic; moderately to } \\
\text { well sorted, mostly subrounded chert fragments and quartz grains } \\
\text { with much less feldspar grains and argillite fragments; silica cement } \\
\text { as quartz overgrowths and chert. Argillite is black (N1), well } \\
\text { indurated, and occurs as dense silicic blocky fragments that take } \\
\text { metal when scratched. Pyrite is rare but occurs throughout interval } \\
\text { in association with both quartzite and argillite. } \\
\text { The amount of quartzite increase with depth, and generally becomes } \\
\text { coarser-grained towards the base of the interval. Many individual } \\
\text { quartzite beds appear to coarsen downward. } \\
\text { Fractures up to } 8 \text { mm in width and completely filled with white (N9) } \\
\text { coarsely crystalline quartz are common, particularly in the quartzite. }\end{array}$ & \multirow[t]{2}{*}{$\begin{array}{l}\text { Eleana } \\
\text { Formation }\end{array}$} \\
\hline $\begin{array}{c}1,069.2-1,674.3 \\
(3,508-5,493)\end{array}$ & $\begin{array}{l}606.9 \\
(1,991)\end{array}$ & $\mathrm{DA}, \mathrm{SC}$ & PTS, XRD & $\begin{array}{l}\text { Shale: Shale is black (N1), moderately to well indurated, weakly } \\
\text { fissile, and silty. Pyrite is rare. Hairline fractures are rare and filled } \\
\text { with quartz. }\end{array}$ & \\
\hline
\end{tabular}




\begin{tabular}{|c|c|c|c|c|c|}
\hline $\begin{array}{l}\text { Depth } \\
\text { Interval } \\
\text { meters } \\
\text { (feet) } \\
\end{array}$ & $\begin{array}{l}\text { Thickness } \\
\text { meters } \\
\text { (feet) }\end{array}$ & $\begin{array}{l}\text { Sample } \\
\text { Type }^{1}\end{array}$ & $\begin{array}{l}\text { Laboratory } \\
\text { Analyses }\end{array}$ & Lithologic Description ${ }^{3}$ & $\begin{array}{c}\text { Stratigraphic } \\
\text { Unit }\end{array}$ \\
\hline $\begin{array}{c}1,674.3-1,783.7 \\
(5,493-5,852)\end{array}$ & $\begin{array}{l}109.4 \\
(359)\end{array}$ & DA & PTS, XRD & $\begin{array}{l}\text { Interbedded Shale, Quartzite, and Sandstone: Shale is black } \\
\text { (N1), moderately indurated, fissile, and silty in part. Quartzite is } \\
\text { dark-gray (N3) to grayish-black (N2), very well indurated, mostly very- } \\
\text { fine- to fine-grained and generally coarsens downward to include } \\
\text { some medium- to coarse-grained beds, moderately to poorly sorted, } \\
\text { subangular to subrounded quartz grains and chert fragments, silica } \\
\text { cemented by mostly chert. Quartzite becomes more abundant below } \\
\text { approximately } 1,737.4 \mathrm{~m} \text { ( } 5,700 \mathrm{ft}) \text {. Sandstone generally occurs } \\
\text { above } 1,737.4 \mathrm{~m}(5,700 \mathrm{ft} \text { ) and is similar to quartzite but appears to } \\
\text { have substantial amounts of calcite and/or dolomitic cement. Some } \\
\text { drill cuttings fragments in samples above } 1,737.4 \mathrm{~m}(5,700 \mathrm{ft}) \text { may } \\
\text { best be described as finely-crystalline, sandy dolomite. } \\
\text { Quartzite and sandstone beds are generally less than } 3 \mathrm{~m} \mathrm{(10} \mathrm{ft)} \\
\text { thick. }\end{array}$ & \multirow[t]{2}{*}{$\begin{array}{l}\text { Eleana } \\
\text { Formation }\end{array}$} \\
\hline $\begin{array}{c}1,783.7-1,874.5 \\
(5,852-6,150)\end{array}$ & $\begin{array}{l}90.8 \\
(298)\end{array}$ & DA & None & $\begin{array}{l}\text { Quartzite: Grayish-black (N2); well indurated; mostly fine-grained, } \\
\text { moderately- to well-sorted, subangular to subrounded grains of quartz } \\
\text { and lesser chert and feldspar, rare fragments of black (N1) shale (rip- } \\
\text { up clasts); } 25 \text { to } 50 \text { percent dark chert cement; weakly pyritic. }\end{array}$ & \\
\hline
\end{tabular}




\begin{tabular}{|c|c|c|c|c|c|}
\hline $\begin{array}{c}\text { Depth } \\
\text { Interval } \\
\text { meters } \\
\text { (feet) } \\
\end{array}$ & $\begin{array}{c}\text { Thickness } \\
\text { meters } \\
\text { (feet) }\end{array}$ & $\begin{array}{l}\text { Sample } \\
\text { Type }\end{array}$ & $\begin{array}{l}\text { Laboratory } \\
\text { Analyses }^{2}\end{array}$ & Lithologic Description ${ }^{3}$ & $\begin{array}{c}\text { Stratigraphic } \\
\text { Unit }\end{array}$ \\
\hline $\begin{array}{c}1,874.5-1,995.2 \\
(6,150-6,546)\end{array}$ & $\begin{array}{l}120.7 \\
(396)\end{array}$ & DA & PTS, XRD & $\begin{array}{l}\text { Interbedded Shale and Quartzite with lesser Sandstone: Shale is } \\
\text { black (N1), moderately indurated, fissile, with sparse pyrite. } \\
\text { Quartzite is dark-gray (N3) to grayish-black (N2), very well indurated, } \\
\text { mostly very-fine- to fine-grained and generally coarsens downward to } \\
\text { include some medium- to coarse-grained beds, moderately to poorly } \\
\text { sorted, subangular to subrounded quartz grains and chert fragments, } \\
\text { silica cemented by mostly chert. Sandstone is similar to quartzite } \\
\text { but appears to have substantial amounts of calcite and/or dolomitic } \\
\text { cement. } \\
\text { Quartzite and sandstone beds are generally less than } 3 \mathrm{~m} \mathrm{(10} \mathrm{ft)} \\
\text { thick and become more abundant towards base of interval. }\end{array}$ & \multirow[t]{2}{*}{$\begin{array}{l}\text { Eleana } \\
\text { Formation }\end{array}$} \\
\hline $\begin{array}{c}1,995.2-2,097.9 \\
(6,546-6,883) \\
\text { TD }\end{array}$ & $\begin{array}{l}>102.7 \\
(>337)\end{array}$ & DA & PTS, XRD & $\begin{array}{l}\text { Quartzite and Sandstone: Quartzite is grayish-black (N2); well } \\
\text { indurated; mostly fine-grained, well-sorted, and subrounded grains of } \\
\text { quartz, feldspar, and chert; weakly calcareous and pyritic; } 25 \text { to } \\
50 \text { percent chert and dolomitic cement. Interbedded with black (N1) } \\
\text { shale and siltstone below approximately } 2,072.6 \mathrm{~m}(6,800 \mathrm{ft}) \text {. }\end{array}$ & \\
\hline
\end{tabular}

1. $\mathbf{D A}=$ drill cuttings that represent lithologic character of interval; $\mathbf{D B} \mathbf{1}=$ drill cuttings enriched in hard components; $\mathbf{D B} 4=$ cuttings that are intimate mixtures of units, generally less than $50 \%$ of drill cuttings represent lithologic character of interval; $\mathbf{S C}=\mathbf{s i d e w a l l}$ core.

2. Completed or planned laboratory analyses. $\mathbf{P T S}=$ polished thin section; $\mathbf{M P}=$ electron microprobe; $\mathbf{X R D}=\mathbf{X}$-ray diffraction; $\mathbf{X R F}=\mathbf{X}$-ray fluorescence; $\mathrm{Fe}^{2+} / \mathrm{Fe}^{3+}=$ wet chemical analysis for iron. See Table 3-2 of this report for additional information.

3. Descriptions are based mainly on visual examination of lithologic samples using a 10x-to 40x-zoom binocular microscope, and incorporating observations from geophysical logs and results of laboratory analyses. Colors describe wet sample color.

Abundances for felsic phenocrysts, pumice fragments, and lithic fragments: trace = only one or two individuals observed; rare $=\leq 1 \%$;

minor $=5 \%$; common $=10 \%$; abundant $=15 \%$; very abundant $\geq 20 \%$.

Abundances for mafic minerals: trace = only one or two individuals observed; rare $=\leq 0.05 \%$; minor $=0.2 \%$; common $=0.5 \%$;

abundant $=1 \%$; very abundant $=\geq 2 \%$. 
This page intentionally left blank.

C-8 


\section{Appendix D \\ Geophysical Logs Run in Well ER-12-2}


Appendix D contains unprocessed data presentations of selected geophysical logs run in Well ER-12-2. Table D-1 summarizes the logs presented. See Table 3-3 for more information.

Table D-1

Well ER-12-2 Geophysical Logs Presented

\begin{tabular}{|c|c|c|c|c|}
\hline Log Type & Run Number & Date & meters & ${ }_{\text {feet }}^{\text {val }}$ \\
\hline Caliper & $\begin{array}{l}\text { CA6-2 } \\
\text { CA6-3 } \\
\text { CA6-4 }\end{array}$ & $\begin{array}{l}11 / 27 / 2002 \\
12 / 18 / 2002 \\
01 / 16 / 2003\end{array}$ & $\begin{array}{c}6.1-182.3 \\
234.7-900.7 \\
853.4-2,094.0\end{array}$ & $\begin{array}{c}20-598 \\
770-2,955 \\
2,800-6,870\end{array}$ \\
\hline $\begin{array}{l}\text { Epithermal Neutron } \\
\text { (porosity) }\end{array}$ & $\begin{array}{l}\text { DSEN-1 } \\
\text { DSEN-2 }\end{array}$ & $\begin{array}{l}12 / 19 / 2002 \\
01 / 17 / 2003\end{array}$ & $\begin{array}{c}237.7-903.1 \\
891.5-2,096.4\end{array}$ & $\begin{array}{c}780-2,963 \\
2,925-6,878\end{array}$ \\
\hline Density & $\begin{array}{l}\text { SDL-1 } \\
\text { SDL-2 }\end{array}$ & $\begin{array}{l}12 / 18 / 2002 \\
01 / 16 / 2003\end{array}$ & $\begin{array}{c}237.7-903.1 \\
891.5-2,096.4\end{array}$ & $\begin{array}{c}780-2,963 \\
2,925-6,878\end{array}$ \\
\hline Induction (resistivity) & $\mathrm{HRI}-1$ & $11 / 25 / 2002$ & $3.0-398.4$ & $10-1,307$ \\
\hline Dual Laterolog (resistivity) & $\begin{array}{l}\text { DLL-1 } \\
\text { DLL-2 }\end{array}$ & $\begin{array}{l}12 / 18 / 2002 \\
01 / 16 / 2003 \\
\end{array}$ & $\begin{array}{c}246.6-899.2 \\
891.5-2,092.5 \\
\end{array}$ & $\begin{array}{r}809-2,950 \\
2,925-6,865 \\
\end{array}$ \\
\hline Spontaneous Potential & $\begin{array}{l}\text { SP-1 } \\
\text { SP-2 }\end{array}$ & $\begin{array}{l}12 / 18 / 2002 \\
01 / 16 / 2003\end{array}$ & $\begin{array}{c}246.6-899.2 \\
891.5-2,092.5\end{array}$ & $\begin{array}{c}809-2,950 \\
2,925-6,865\end{array}$ \\
\hline Gamma Ray & $\begin{array}{c}\text { GR-2 } \\
\text { GR-9 } \\
\text { GR-14 }\end{array}$ & $\begin{array}{l}11 / 25 / 2002 \\
12 / 18 / 2002 \\
01 / 16 / 2003\end{array}$ & $\begin{array}{c}3.0-393.8 \\
237.1-884.5 \\
891.5-2,084.2\end{array}$ & $\begin{array}{c}10-1,292 \\
778-2,902 \\
2,925-6,838\end{array}$ \\
\hline Full-wave Sonic - Delta T & $\begin{array}{l}\text { FWS-1/GR-10 } \\
\text { FWS-2/GR-16 }\end{array}$ & $\begin{array}{l}12 / 19 / 2003 \\
01 / 17 / 2003\end{array}$ & $\begin{array}{c}237.7-899.2 \\
883.9-2,093.7\end{array}$ & $\begin{array}{c}762-2,950 \\
2,900-6,869\end{array}$ \\
\hline $\begin{array}{c}\text { Spectral Gamma Ray } \\
\text { (potassium, thorium, uranium) }\end{array}$ & $\begin{array}{l}\text { SGR-1 } \\
\text { SGR-4 } \\
\text { SGR-5 }\end{array}$ & $\begin{array}{l}11 / 25 / 2002 \\
12 / 18 / 2002 \\
01 / 16 / 2003\end{array}$ & $\begin{array}{c}3.0-393.8 \\
237.1-884.5 \\
891.5-2,084.2\end{array}$ & $\begin{array}{c}10-1,292 \\
778-2,902 \\
2,925-6,838\end{array}$ \\
\hline Chemistry/Temperature & Chem-1/TL-6 & 01/19/2003 & 899.2 - 2,097.9 & $2,950-6,883$ \\
\hline Thermal Flow Meter & TFM-1 & $01 / 19 / 2003$ & $883.9-1,768.8$ & $2,900-5,800$ \\
\hline
\end{tabular}




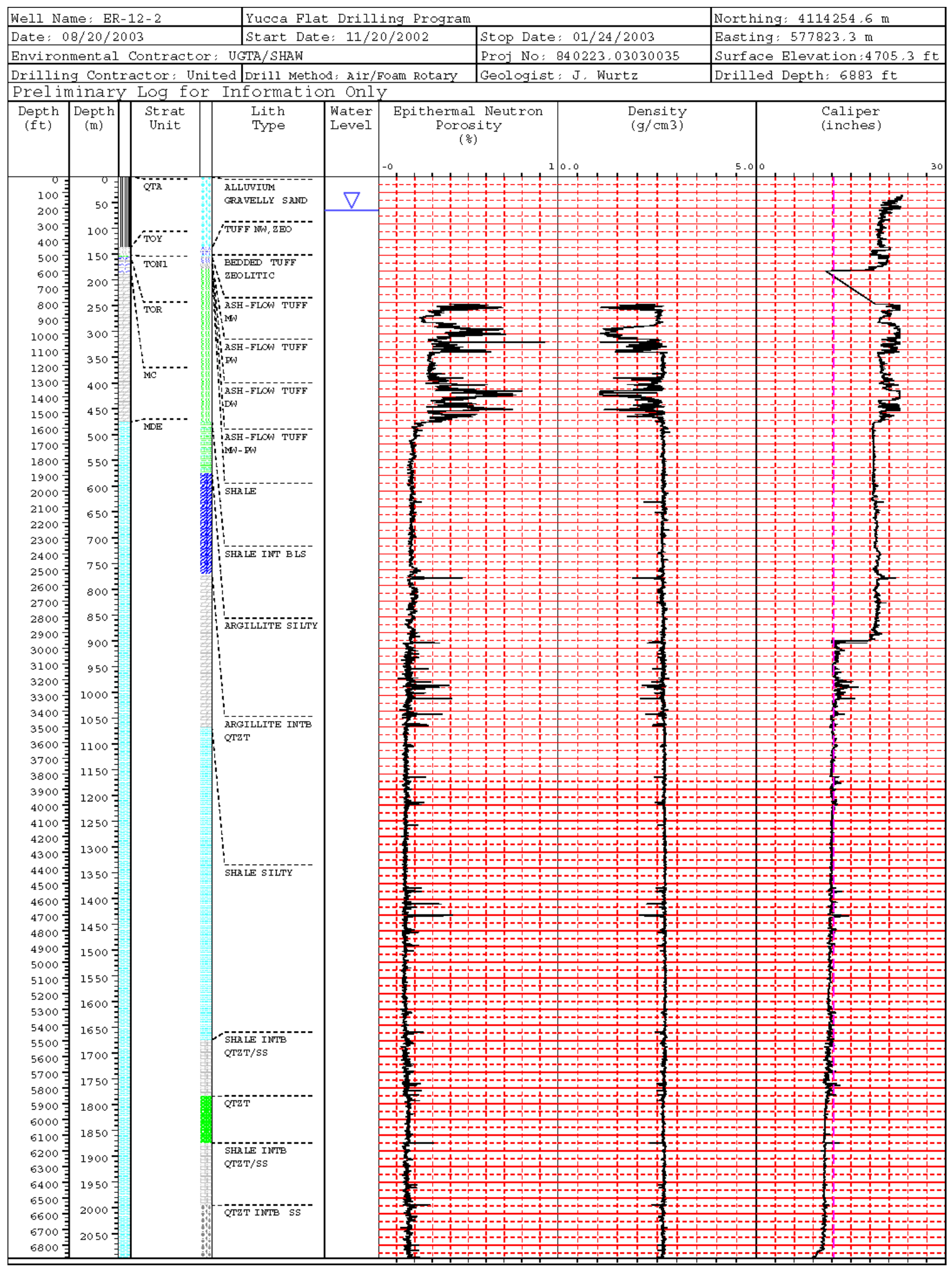




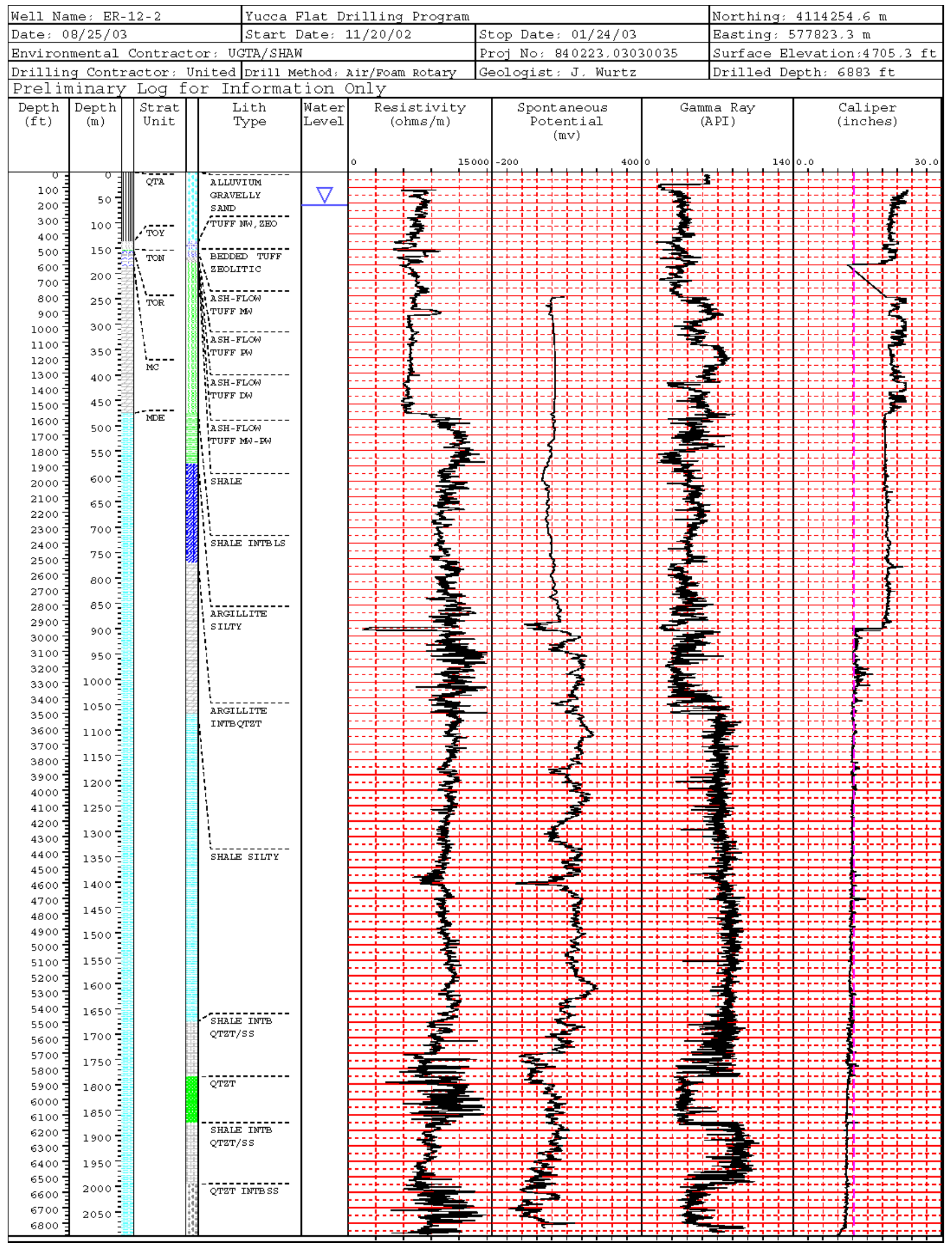




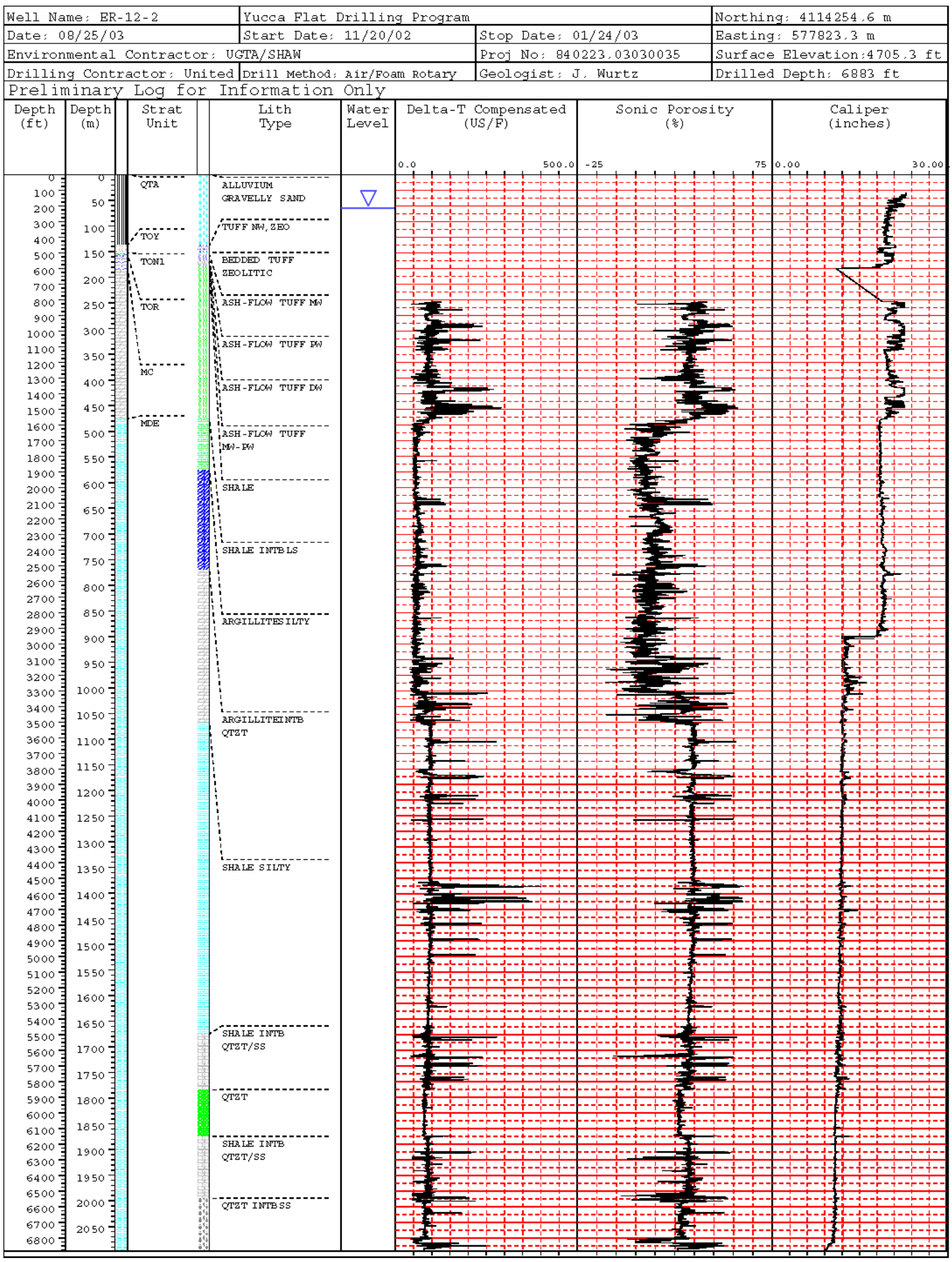




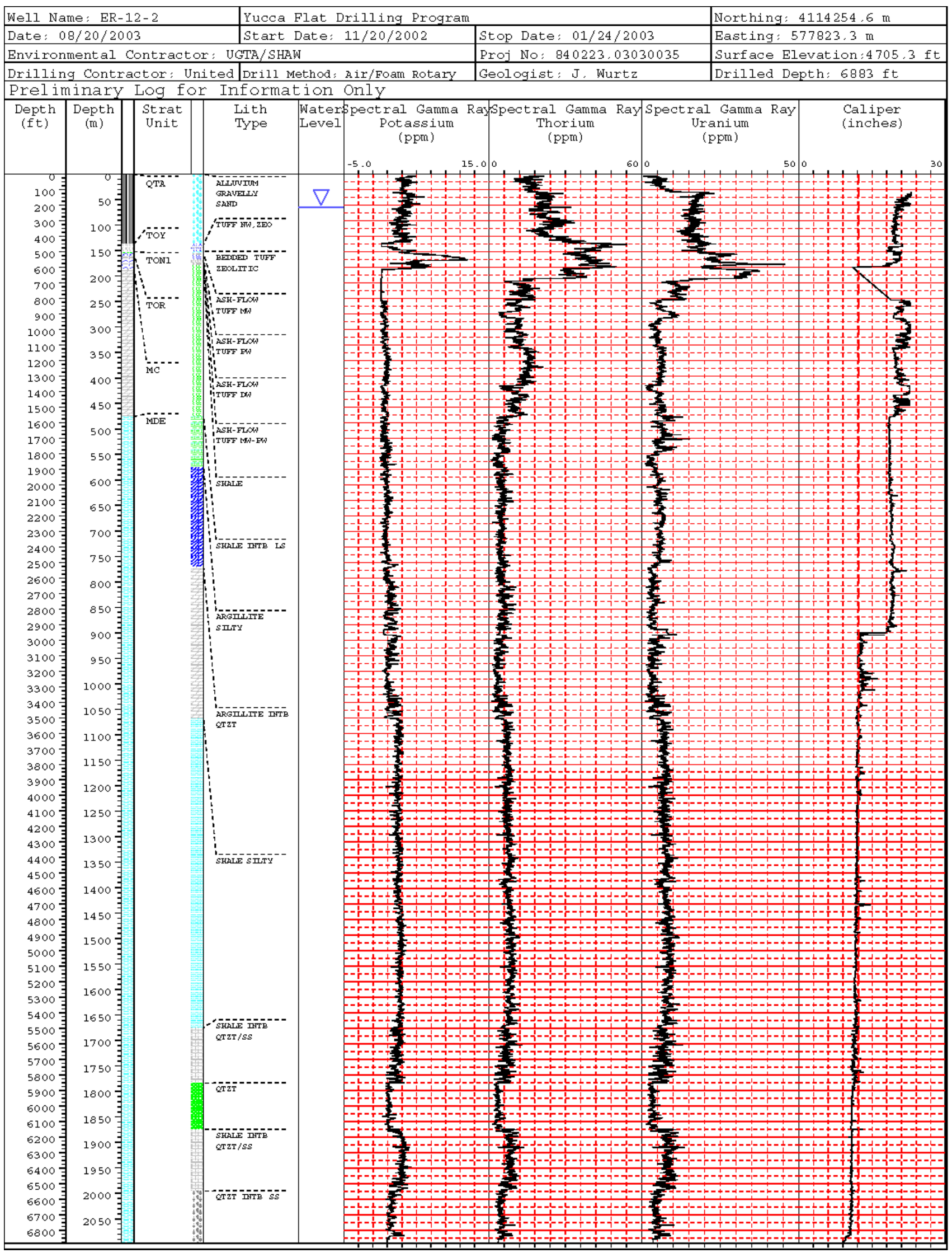

D-5 


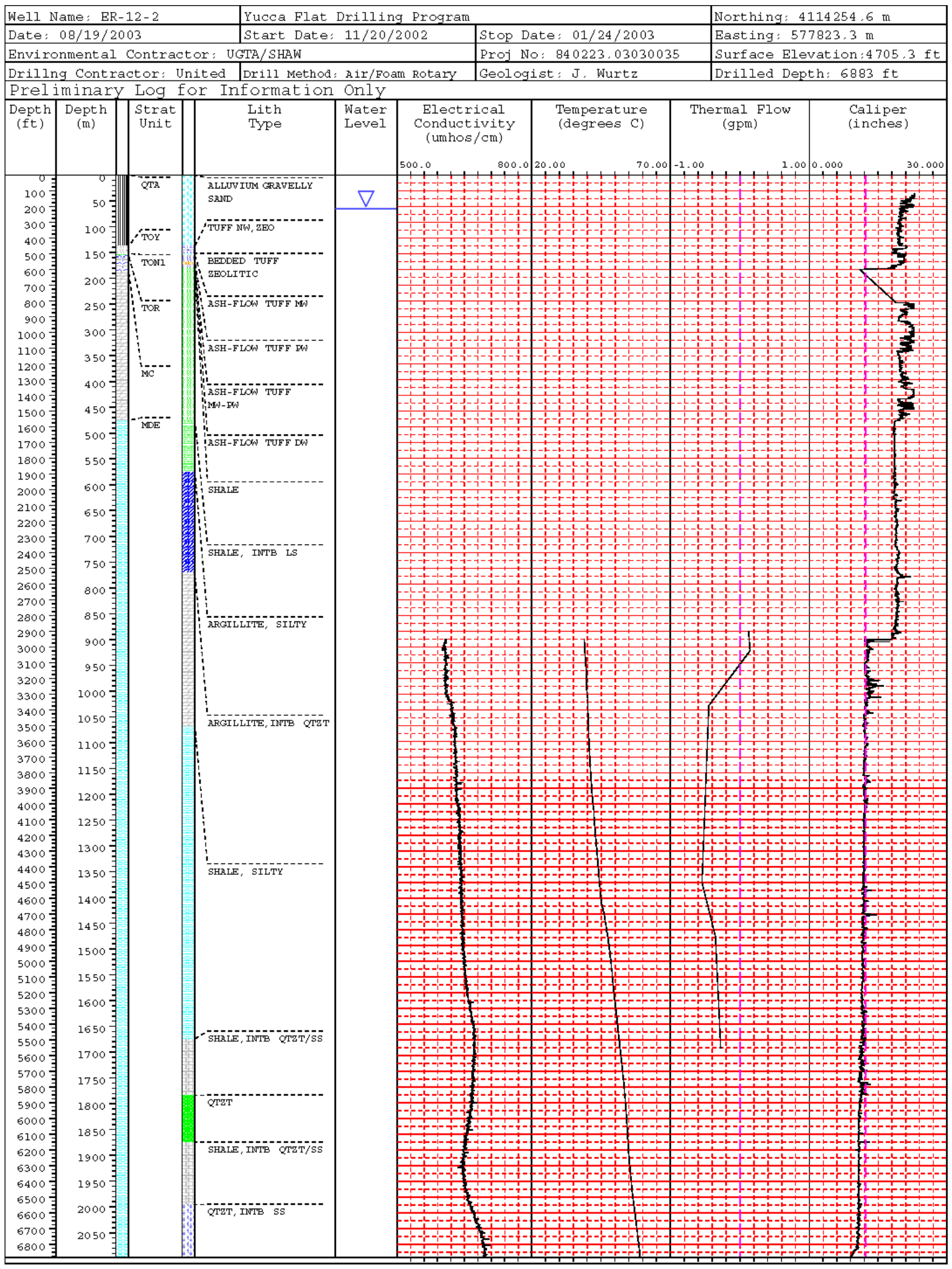




\section{Distribution List}

$\underline{\text { Copies }}$

R. M. Bangerter

U.S. Department of Energy

National Nuclear Security Administration

Nevada Site Office

Environmental Restoration Division

P.O. Box 98518, M/S 505

Las Vegas, NV 89193-8518

U.S. Department of Energy

National Nuclear Security Administration

Nevada Site Office

Technical Library

P.O. Box 98518, M/S 505

Las Vegas, NV 89193-8518

U.S. Department of Energy

National Nuclear Security Administration

Nevada Site Office

Nuclear Testing Archive

Public Reading Facility

P.O. Box 98518, M/S 400

Las Vegas, NV 89193-8518

U.S. Department of Energy

1 (electronic)

Office of Scientific and Technical Information

Post Office Box 62

Oak Ridge, Tennessee 37831-0062

K. A. Hoar, Director

U.S. Department of Energy

National Nuclear Security Administration

Nevada Site Office

Environment, Safety and Health Division

P.O. Box 98518, M/S 505

Las Vegas, NV 89193-8518

P. K. Ortego

Bechtel Nevada

P.O. Box 98521, MS NLV082

Las Vegas, NV 89193-8521 


\section{Distribution List (continued)}

\section{$\underline{\text { Copies }}$}

John McCord

UGTA Project Manager

Stoller-Navarro

7710 West Cheyenne Ave.

Building 3

Las Vegas, NV 89129

Stoller-Navarro Library

Stoller-Navarro

7710 West Cheyenne Ave.

Building 3

Las Vegas, NV 89129

W. L. Hawkins

Los Alamos National Laboratory

P. O. Box 1663

Los Alamos, NM 87545-1663

G. A. Pawloski

Lawrence Livermore National Laboratory

P. O. Box 808

Livermore, CA 94551-0808

T. P. Rose

Lawrence Livermore National Laboratory

P. O. Box 808

Livermore, CA 94551-0808

B. K. Thompson

DOE/USGS Cooperative Program Manager

U.S. Geological Survey

Water Resources Division

6770 South Paradise Road

Las Vegas, NV 89119-3721

C. E. Russell

Desert Research Institute

755 East Flamingo Road

P.O. Box 19040

Las Vegas, NV 89119-7363 